\title{
THE TRAVELERS
}

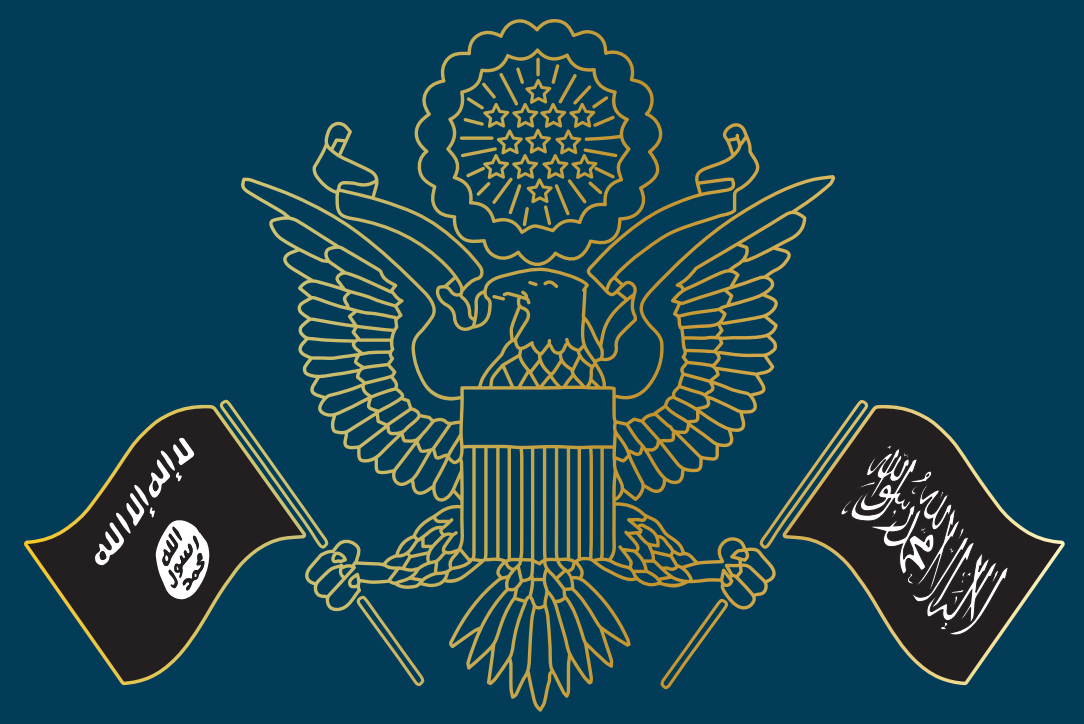

American Jihadists in Syria and Iraq

Alexander Meleagrou-Hitchens, Seamus Hughes, Bennett Clifford FEBRUARY 2018

\section{Program on Extremism}





\title{
THE TRAVELERS \\ American Fihadists in Syria and Iraq
}

\author{
BY \\ Alexander Meleagrou-Hitchens, Seamus Hughes, Bennett Clifford \\ Program on Extremism \\ February 2018
}

Program on Extremism

THE GEORGE WASHINGTON UNIVERSITY 
All rights reserved. Printed in the United States of America. No part of this publication may be reproduced or transmitted in any form or by any means, electronic or mechanical, including photocopy, recording, or any information storage and retrieval system, without permission in writing from the publisher.

๑ 2018 by Program on Extremism

Program on Extremism

2000 Pennsylvania Avenue NW

Washington, DC 20006

www.extremism.gwu.edu 


\section{Contents}

Acknowledgements ............................................................................................ v

A Note from the Director .......................................................................................... vii

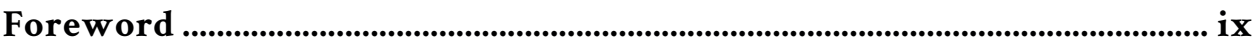

Executive Summary .......................................................................................................... 1

Introduction: American Jihadist Travelers ................................................................5

Foreign Fighters and Travelers to Transnational Conflicts:

Incentives, Motivations, and Destinations............................................................... 5

American Jihadist Travelers: 1980-2011 ...................................................................... 6

How Do American Jihadist Travelers Compare to Other Western Counterparts? .............8

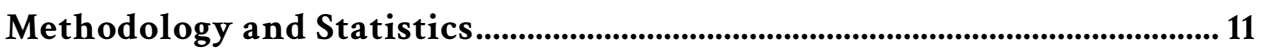



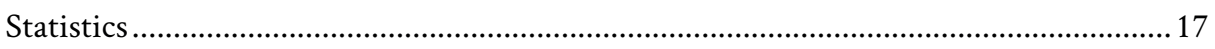

Category 1: Pioneers ....................................................................................... 23

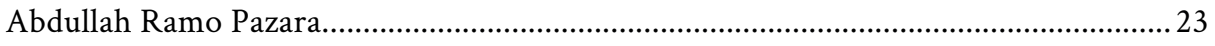

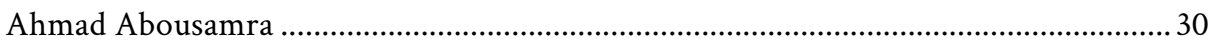

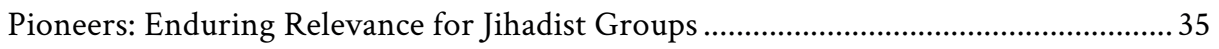

Category 2: Networked Travelers ..................................................................... 39

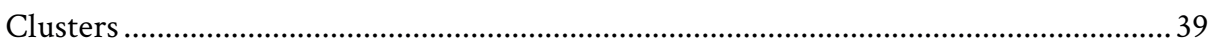

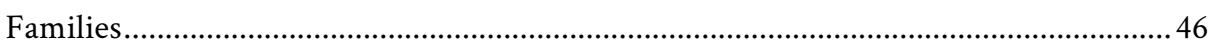

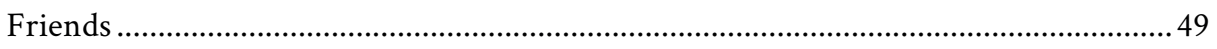

Networked Travelers: Why "Strength in Numbers" Matters ........................................52

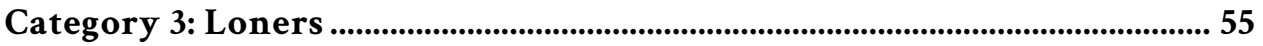

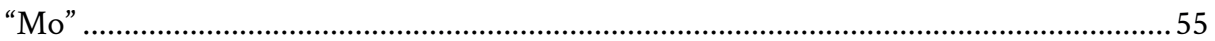

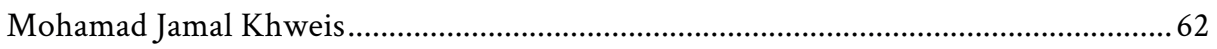



Returning American Travelers ...................................................................71

Recruitment, Returnees, Reintegration: Challenges

Facing the U.S. Regarding Jihadist Travelers ....................................................... 71

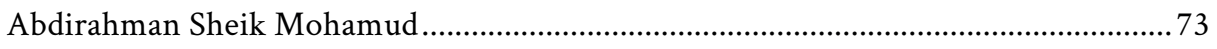

Criminal Justice Approaches to Returning Travelers .................................................. 75

Addressing the Threat of American Jihadist Travelers ................................ 79

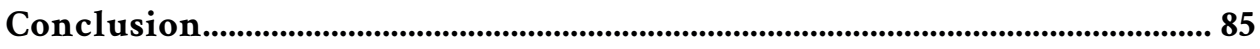

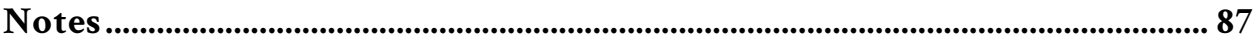





\section{Acknowledgements}

$\mathrm{T}$

his report was made possible by the dedicated and tireless work of the Program on Extremism's staff. The authors wish to thank the Program's Director Dr. Lorenzo Vidino, as well as research fellows Audrey Alexander, Katerina Papatheodorou, and Helen Powell for their invaluable insight and significant contributions to the methodology and construction of this report. Several of the Program's research assistants, including Silvia Sclafani, Tanner Wrape, Sarah Metz, Grant Smith, Gianluca Nigro, and Aaron Meyer, assisted in editing and verifying the final product. The authors also thank Larisa Baste for designing this report.

The views expressed in this publication are solely those of the authors, and not necessarily those of the George Washington University.

\section{The Program on Extremism}

The Program on Extremism at the George Washington University provides analysis on issues related to violent and non-violent extremism. The Program spearheads innovative and thoughtful academic inquiry, producing empirical work that strengthens extremism research as a distinct field of study. The Program aims to develop pragmatic policy solutions that resonate with policymakers, civic leaders, and the general public. 



\section{A Note from the Director}

Since its foundation, the Program on Extremism has made analysis of all aspects of the Syria and Iraq-related jihadist mobilization in the United States one of its cornerstones. In 2015, it released its flagship report, ISIS in America: From Retweets to Raqqa, which provided the foundation for various congressional hearings and is currently used as a training text by law enforcement and intelligence agencies throughout the country. The Program then released several groundbreaking studies: Cruel Intentions: Female Jihadists in America, a seminal study on the radicalization of women; Fear Thy Neighbor: Radicalization and Jihadist Attacks in the West, which analyzed all jihadist attacks in the West since the declaration of the Caliphate; and Digital Decay: Tracing Change Over Time Among English-Language Islamic State Sympathizers on Twitter, part of the Program's larger effort to monitor various jihadist activities online. The Program also regularly releases two related products: the Extremism Tracker, our monthly update which details terrorism-related activities and court proceedings in the United States, and the Telegram Tracker, a quarterly analysis documenting our researchers' data collection of pro-Islamic State channels with English-language content on the messaging application Telegram.

Our latest report, The Travelers: American Jihadists in Syria and Iraq, provides a uniquely comprehensive analysis of the phenomenon of American foreign fighters in Syria and Iraq. Drawing on thousands of pages of documents and dozens of exclusive-access interviews (including with returning foreign fighters), the report describes a phenomenon that is bound to have enormous implications on the security environment for the coming years. As the nature of the threat evolves, the Program on Extremism is committed to continuing its effort to produce evidence-based and non-partisan analysis to support sound policymaking and public debate.

Dr. LORENZO Vidino

Director, Program on Extremism

February 2018 



\section{Foreword}

By Brian Mighael Jenkins

$\mathrm{T}$ he declaration of a caliphate by $\mathrm{Abu}$ Bakr alBaghdadi in 2014 generated excitement among Salafi-jihadist Muslims worldwide. Here, at last, was the restoration of the long-awaited Islamic State that would go on to conquer the world for Islam. Coming at the crest of victories by the forces of the Islamic State of Iraq and al-Sham (ISIS), an organization that traced its origins to the insurgency in Iraq following the American-led invasion of that country, Baghdadi's audacious assertion seemed to carry weight.

The anti-government protests in Syria-one dimension of the wave of uprisings that swept across North Africa and the Middle East beginning in 2011-and the Syrian government's brutal response, had already attracted foreign volunteers to the ranks of the rebels. The Islamic State, as the caliphate was called, attracted tens of thousands of additional recruits, far more than the mujahideen who joined the Afghan resistance against Soviet occupation in the 1980s or those who passed through al-Qaeda's training camps in the 1990s.

Some recruits came to the Islamic State as pilgrims, escaping what they considered to be the oppression of residing among infidels, to live among like-minded believers and build the new province of faith. Others came to fight in the ranks of the Islamic State's forces, perhaps to participate in the final battle between Muslims and unbelievers, prophesized in Sunni eschatology. Still others came to gain the training and battle experience that would enable them to assemble new organizations that would launch new jihadist fronts at home.

The declaration of the Islamic State posed little immediate threat to U.S. homeland security, although ISIS went out of its way to provoke revulsion and create enemies abroad. The reaction in Washington was one of alarm. One alarmed senator asserted that "we are in the most dangerous position we ever have been as a nation." Another warned that American troops had to be sent to
Syria "before we all get killed here at home." The public mostly agreed.

In response to the Islamic State's atrocities, an Americanled coalition began bombing ISIS targets and assisting Iraqi and locally recruited ground forces in September 2014. Meanwhile, Syrian government forces and Iraniancreated militias, assisted by Russian air power beginning in 2015, closed the ring on the Islamic State's forces in western Syria.

While guerrillas and terrorists are difficult to destroy, defending territory in open battle against militarily superior foes is generally a losing proposition. By the end of 2017, the territorial expression of the Islamic State had been almost entirely eliminated, although most analysts believed that the armed struggle would continue.

Many of the foreign fighters died in the defense of cities and towns held by the Islamic State. They were fervent and expendable. They were often volunteers for suicide missions. And they would have no future in an underground contest, especially those from countries outside of the region. Those not killed fled, some to other jihadist fronts; many returned home.

Some of the returnees, no doubt, were disillusioned by the brutal experience of life under the bloodthirsty rule of the Islamic State's merciless application of its interpretation of Islamic governance, although some foreign fighters enthusiastically participated in its barbarities. Some were traumatized by the savage warfare that marked its defeat. Yet some escaped with their commitment intact, determined to carry on the jihad. As this book illustrates, the recruiters for future jihads arise from past jihadist campaigns.

This excellent volume examines the experience of the American jihadists in Syria and Iraq. It represents another installment in the continuing research carried out by George Washington University's Program on 
Extremism, which has already produced a number of informative reports on various aspects of radicalization.

Far fewer foreign volunteers traveled to the Islamic State from the United States than from Europe. The estimated number of foreign volunteers from Europe ranges from 5,000 to 6,000, most of them from France, Belgium, Germany and the United Kingdom, while U.S. officials speak of several hundred-an all-in number that includes those arrested before leaving the United States, those arrested abroad, and those known to be killed. The numbers remain a bit murky. Most of the 250 to 300 American jihadist recruits mentioned by authorities have not been publicly identified, suggesting on-going investigations, sealed indictments, and some uncertainty.

This study examines 64 of these travelers in greater detail than any previous study. The thoroughness of the research offers new insights. It is typically not the purpose of a foreword to summarize a book's conclusions, but some of the authors' observations merit reinforcement. One is that, consistent with earlier research, there is no single profile of the American travelers and their motives vary greatly.

While much is made of the Islamic State's recruiting via the Internet and social media, the authors find that in-person contacts played a major role in recruiting and facilitating travel from the United States to Syria. It would be an overstatement to say that there is an organized jihadist underground in the United States, but this research shows that there is a patchwork of connections, some reaching back to the Balkans conflicts of the early 1990s. This connectivity offers domestic intelligence operations with leads to unravel and suggests that a small number of key individuals play a significant role in any new mobilization. Ensuring that the connections do not coalesce into a larger web must be a primary objective of counterterrorism strategy.

Returning foreign fighters pose only one dimension of a multilayered threat. Some analysts fear that the Islamic State's leadership will seek to launch major terrorist attacks in the West in revenge for the destruction of the caliphate.
Deprived of its nation-building message, the Islamic State's propaganda now focuses on war. U.S.-bound commercial flights offer another vector of terrorist attack, one that has engrossed al-Qaeda in the Arabian Peninsula. Most jihadist terrorist plots in the United States, however, have been the schemes of domestic jihadists who did not go abroad. They are more likely to carry out attacks than are returning travelers.

The good news is that the destruction of the Islamic State's territorial enterprise deprives fervent jihadists of an accessible destination. However, this is also the bad news. The most determined, most prone to violence, have nowhere to go. Will the closing of this escape valve presage an increase in homegrown jihadist plots?

The numbers suggest that only a fraction of the volunteers who traveled to the Islamic State will return. And thus far, very few of those returning to Europe or the United States have been involved in plotting terrorist attacks after their return. But as demonstrated in the 2014-2016 terrorist campaign in France and Belgium, the greatest danger comes from a combination of returning foreign fighters and local confederates. The United States, however, lacks the large, alienated immigrant diasporas of Europe where returning foreign fighters can more easily find hideouts and accomplices. It is important that American attitudes and policies do not create such conditions.

Arrest, surveillance, and suspicion by other would-be jihadists who fear that any returning foreign fighters still at large are likely to be police informants may suffice to keep the returnees isolated. Imprisonment alone will not solve the problem. Most homegrown jihadists as well as those who went abroad were first radicalized in the United States. Returnees disillusioned by their experience abroad could be recruited in efforts to discourage homegrown terrorism and recruitment to new jihadist fronts abroad.

Brian Michael Jenkins

February 2018

$x$ | THE GEORGE WASHINGTON UNIVERSITY PROGRAM ON EXTREMISM 


\section{Executive Summary}

$\mathrm{T}$ his study reflects the most comprehensive, publicly available accounting of Americans who traveled to join jihadist groups in Syria and Iraq since 2011. It identifies 64 travelers, the largest available sample to date. These individuals, and their stories, were uncovered during a multi-year investigation. Authors interviewed law enforcement officials, prosecutors, and defense attorneys, and attended relevant court proceedings. Additionally, they reviewed thousands of pages of legal documents, filing information requests and federal court motions to unseal records where necessary. Finally, the authors conducted several interviews with American travelers who returned from the territories held by the Islamic State (IS).

Travel or attempted travel to jihadist-held territory in Syria and Iraq is one of the most popular forms of mobilization for American jihadist sympathizers. In addition to successful travelers, at least 50 Americans attempted to travel but were prevented from doing so by law enforcement. These cases constitute approximately onethird of the 153 Americans who have been arrested on Islamic State-related charges from 2011 to 2017. Cases of travel or attempted travel to Syria or Iraq have steadily decreased since 2015.

The study finds that there is no single profile of an American traveler, although some demographic trends reflect the broader population of jihadist supporters in the United States. Travelers tend to be male, with an average age of 27 . They generally affiliated with IS upon arrival in Syria or Iraq. The three states with the highest proportional rates of recruitment are Minnesota, Virginia, and Ohio.

Based on the underlying factors behind their travel, how they made their journey, and what role they took in jihadist groups, American travelers can broadly be classified using the following three categories. Using case studies, this report contains analyses of each category of traveler.
- Pioneers arrived early in Syria and Iraq and ascended to some level of leadership in their respective jihadist organizations. They are distinguished from other travelers due to previous experience with critical skills relevant to their organization-such as military training, past participation in jihadist movements, proficiency in religious doctrine or producing ideological material, and technical skills (bomb-making, computer skills, etc.). Due to these abilities, pioneers attain coveted positions within jihadist groups. They often use their roles to reach out to individuals within their network and encourage them to provide support to jihadist groups. However, only a select few individuals have the skills and abilities necessary to become pioneers. Four travelers (6.3\%) in the sample are coded as pioneers, making it the smallest category in number, but far larger if assessed in terms of their impact on the jihadist movement.

- Networked travelers use personal contacts with like-minded supporters of jihadist groups in the U.S. to facilitate their travel. In some of these cases, a group of individuals, usually connected by kinship, friendship, or community ties, travel together to Syria or Iraq. Others, while traveling by themselves, had contact with individuals in the U.S. who supported their journey by providing financial or logistical support, or with individuals who were involved in supporting jihadist groups in other ways (e.g. through committing or planning attacks). These groups can be as small as two, and in one case, at least a dozen individuals, all from the same community and/or social network. Eighty seven percent of the travelers for whom information is available had some form of personal connection to other travelers or jihadist supporters.

- Loners are exceptions to the norm regarding the recognized importance of networks in facilitating travel. In contrast to networked travelers, loners travel seemingly without the assistance of anyone 
whom they know personally. Yet, despite apparently lacking these facilitative links, they manage to reach Syria and Iraq without being apprehended. To make up for the lack of personal connections, loners often turn to the internet, reaching out to virtual connections who assist them in making the decision to travel and completing the journey. Six cases (9.4\%) in the sample were coded as loners. Loners' stories counter common assumptions regarding jihadist mobilization and travel facilitation. Due to the complex, individualized factors that drive their personal decisions, developing responses to loners is an exceptional challenge.

The U.S. faces differing threats from each category. Of significant concern to U.S. law enforcement is the specter of American travelers returning to the U.S. from Syria and Iraq. American returned travelers may bolster domestic jihadist networks by sharing expertise, radicalizing others, or committing attacks.

This study finds that to date, the phenomenon of returning travelers has been limited in the U.S. context. From the 64 travelers identified by name, 12 returned to the U.S. Nine of those returnees were arrested and charged with terrorism-related offenses. The remaining three have, so far, not faced public criminal charges related to their participation in jihadist groups in Syria or Iraq.

As of January 1, 2018, no returned travelers from Syria and Iraq have successfully committed a terrorist attack in the U.S. following their re-entry. Only one of the 12 returnees identified in this study returned with the intent to carry out an attack on behalf of a jihadist group in Syria. This individual was apprehended in the early planning stages of their plot.

Therefore, the risk of returned travelers being engaged in terrorist attacks has, to date, been limited. There have been 22 jihadist attacks from 2011 to 2017; none of them were committed by a perpetrator who was known to have traveled to Syria and Iraq to join jihadist groups. Thus, "homegrown" extremists currently appear to be more likely to commit domestic jihadist attacks than returning travelers.
Yet, returning travelers pose other threats. If left unaddressed, returnees can augment jihadist networks in the U.S., provide others with knowledge about how to travel and conduct attacks, and serve as nodes in future jihadist recruitment. Throughout the history of American jihadist travelers, several individuals who were formative to future mobilizations had returned to the U.S. from fighting with jihadist groups overseas.

To address this threat, the U.S. may consider broadening its options to counter jihadist travel and respond to the risk from returnees.

- The American traveler contingent defies a single profile, and approaches should account for their diverse nature. The categories of travelers presented in this study can assist in developing a basis for classification and review of the threat posed by individual travelers.

- The roles of travelers who hold non-combatant roles in jihadist groups should be considered. Of note are women travelers, who traditionally assume auxiliary roles in jihadist groups. They function in logistical and financial capacities, as well as more communal, day-to-day operations. The U.S. should also develop a comprehensive process for returning children, who cannot be prosecuted and should be re-integrated into society.

- Unlike many other countries, American laws criminalizing jihadist travel were in place well before the mobilization to Syria and Iraq. The statutory law offers law enforcement flexibility and leeway in charging travelers. However, in some cases, prosecution is infeasible. At times, it is difficult to garner evidence about a traveler's activities in Syria and Iraq that is admissible in a court of law. As a result, prosecutors are often forced to charge returned travelers with lesser offenses. While the average prison sentence for individuals who attempted (but failed) to travel to Syria and Iraq is approximately 14 years, the seven successful travelers that have been convicted from 2011-2017 received an average sentence of ten years in prison.

2 | THE GEORGE WASHINGTON UNIVERSITY PROGRAM ON EXTREMISM 
- Considering that many convicted American travelers will be released within the next five to ten years, prison deradicalization programs should be regarded as a priority. There are no deradicalization or rehabilitation programs for jihadist inmates in the U.S. federal prison system. Without these programs, incarcerated travelers have few incentives to renege on their beliefs, and may attempt to build networks in prison or radicalize other prisoners.

- Programs designed to prevent future radicalization also require sustained official attention. Disillusioned American returnees may have some role to play in these programs as effective providers of interventions. If national-level targeted intervention programming is developed, efforts can be informed by the successes and failures of local initiatives, as well as similar projects developed in other countries.

- Digital communications technologies are useful tools for facilitating jihadist travel. Yet, regulation (e.g. censorship, content and account deletion, regulating or banning privacy-maximizing tools) of online platforms favored by jihadists may have little effect on travel facilitation networks. While the availability of jihadist propaganda has undoubtedly diminished on open platforms due to content removal, American travelers tend to access such material on lesser-known online repositories. Travelers also migrated to alternative social media platforms and use a range of privacy-maximizing services-including virtual private networks, anonymous browsers, and encrypted messengers-to access content, communicate with recruiters, and mask their locations.

If the previous mobilizations of American jihadists to Afghanistan, Bosnia, Pakistan, Yemen, Somalia, or elsewhere are any guide, individuals and dynamics from one mobilization often play outsized roles in future recruitment networks. Therefore, it is incumbent upon the U.S. government, American civil society organizations, and scholars of jihadism to use the lessons from the Syria- and Iraq-related mobilizations to develop proactive and comprehensive policies to address American jihadist travel. 



\section{Introduction: American Jihadist Travelers}

ince the outbreak of the Syrian conflict in 2011, the
Federal Bureau of Investigation (FBI) has reported that 300 Americans attempted to leave or have left the U.S. with the intention of fighting in Iraq and Syria. ${ }^{1}$ While the details of many of these cases remain either unknown or obscure, this study is among the first to offer an overview and analysis of America's jihadist travelers. Drawing on an array of primary sources, including interviews with returnees, court documents, and the online footprints of known travelers, it sheds light on why and how they joined jihadist groups, and what threat they currently pose to the U.S.

After an introductory discussion of the current literature on the topic, including the history of American involvement in foreign jihadist conflicts, the study provides the most comprehensive publicly available statistical breakdown of this phenomenon. This approach helped inform the creation of a new typology of jihadist travelers: pioneers, networked travelers, and loners. These sections will also include select in-depth analyses of some of the more revealing case studies that best exemplify each category. Next, the report documents cases of American travelers who returned to the U.S., assessing their threat and the current U.S. response. The study concludes with a set of recommendations for both government and civil society.

\section{Foreign Fighters and Travelers to Transnational Conflicts: Incentives, Motivations, and Destinations}

In absolute terms, the current mobilization of foreign fighters and jihadist travelers to Syria and Iraq outnumbers all other mobilizations to jihadist conflicts during the past 40 years. $^{2}$ Estimates of the total number of foreigners who have traveled to Syria and Iraq broadly range between 27,000 and 31,000, the majority of whom originate from North Africa and the Middle East. ${ }^{3}$ At its peak, an estimated 2,000 jihadist travelers were crossing the Turkish border into Syria weekly; since 2016, this number has decreased to around 50 crossings due to the declining territorial holdings of the Islamic State of Iraq and Syria (IS) and increased border enforcement by the Turkish government. ${ }^{4}$

\section{Foreign Fighters vs. Travelers}

David Malet defines the term "foreign fighters" as "non-citizens of conflict states who join insurgencies during civil conflicts." ${ }^{5}$ According to this definition, "foreign fighters" would comprise a significant percentage of the individuals in the sample. However, it is worth noting that this terminology does not account for individuals who joined the Syrian and Iraqi jihadist insurgencies with different motives, roles, and backgrounds. Instead, this study uses the term "travelers" to refer to the U.S. persons who have traveled to Syria or Iraq since 2011 to participate in jihadist formations.

The term "foreign fighter" presumes an individual's motivations, and their role in the organization in question. While most of the individuals in the sample left their homes for Syria and Iraq specifically to participate in conflict and served in combat roles upon arrival, some did not. The rise of IS, whose mission was framed not only in terms of attacks and military campaigns but also addressed legitimate, religio-political governance, drew individuals who (albeit misguidedly) traveled to join the group in the hopes of living peacefully in the new, self-declared Caliphate while avoiding combat. It is also important to point to the roles of women in these jihadist organizations; while most groups prohibit women from combat, they hold active and essential positions in day-to-day operations and management. ${ }^{6}$ Thus, the term "traveler" more closely encapsulates not only those who travel to fight in jihadist groups, but also those with different intentions.

\section{Motivations}

Currently, the Syrian conflict has the lion's share of the global base of jihadist recruits. ${ }^{7}$ Yet, it is a mistake to assume that all travelers were drawn to Syria for 
the same reasons. Many travelers who left for Syria in the years directly after 2011 did so in reaction to perceived injustices committed by the Syrian regime. Some were not attracted to a specific jihadist group prior to traveling, but later made networked connections that dictated their choice of organization. A number of these individuals likely went abroad rather than staying home to plot attacks largely because of the opportunity and "social desirability" of waging jihad. ${ }^{8}$ However, with the emergence of specific organizations like IS and Jabhat al-Nusra (JN), an increasing number of travelers had decided which group to join prior to leaving.

Before 2011, data on travelers were largely incomplete. The overall number provided small sample sizes unsuitable for generalization. Scholars are still at an impasse in determining the factors that have led to jihadist travel over the years; however, new data establish some macro-level trends. ${ }^{9}$ The recent Syria and Iraq-based mobilizations generated a more extensive dataset of jihadist travelers for study. When analyzed, they disprove some common explanations of why individuals travel abroad to participate in jihadist organizations.

The overarching assessment of scholars of jihadist radicalization and mobilization is that sweeping, unidimensional theories of why individuals fight overseas lack methodological rigor, are driven by political or personal biases, or both. ${ }^{10}$ The most comprehensive studies utilize a multitude of methods from across social and political sciences to explain what is, in essence, a highly personalized and individual decision. They also admit that a theory which is useful in one test case may not be helpful in another.

Some theories of mobilization focus on socio-economic barriers (unemployment, poverty, "marginalization"/ lack of societal integration) as motivators for individuals to fight abroad. At face value, some of these factors may appear to be reasonable or logical explanations for mobilization. At best, however, studies have demonstrated a weak correlation between economic variables and jihadist travel. ${ }^{11}$ On one hand, some studies find that a substantial number of individual jihadist travelers from a specific country had financial problems, were unemployed, or living on social welfare. ${ }^{12}$ However, when applied to the American context, these trends appear to be less illustrative. The sample of American IS supporters cut across economic boundaries, and American Muslims as a population tend to experience greater levels of economic success and integration than their counterparts in other Western countries. ${ }^{13}$ Simultaneously, a near-consensus of studies also show that there is no correlation between a country's economic performance indicators and the number of travelers in Syria and Iraq from that country. ${ }^{14}$

Another single-factor theory that merits discussion is the argument that jihadist traveler mobilization stems from increased access to digital communications technology, and the strategies that jihadist organizations use to recruit and mobilize followers online. Undeniably, the internet has become foundational to how jihadist organizations recruit, network, and communicate within their ranks; a number of cases within this dataset reflect these dynamics. That notwithstanding, there are very few cases wherein a traveler radicalized, decided to travel, traveled, and reached their destination without any offline connections. ${ }^{15}$ At some point in this process, travelers must make the jump from the online world into real-life interactions. ${ }^{16}$

\section{American Jihadist Travelers: 1980-2011}

Some estimates place the number of U.S. persons involved in overseas jihadist movements from 1980 to 2011 at more than a thousand. ${ }^{17}$ During this 30 -year period, the destinations chosen by Americans fighting overseas varied geographically and temporally. The conflicts and areas that drew in the most American jihadist travelers included the conflict in Afghanistan during the 1980s, the 1990s civil war in Bosnia, and the mid-2000s campaigns waged by al-Shabaab in Somalia and al-Qaeda and Taliban affiliates on the Afghanistan-Pakistan border. ${ }^{18}$ There is additional evidence of American jihadist participation in other conflicts, including in Yemen and the North Caucasus.

The major networks of jihadist traveler recruitment in the U.S. mainly began during the Soviet occupation of 
Afghanistan. ${ }^{19}$ Several individuals linked to the initial iteration of al-Qaeda, including the "father of jihad" Abdullah Azzam, were active in recruiting Americans to join the mujahideen (jihadist fighters) fighting against the Soviet Union in Afghanistan. ${ }^{20}$ Under the front of charity or relief organizations, these recruiters set up shop in several American cities and drew from the base of individuals who attended their lectures and speeches to recruit foreign fighters. ${ }^{21}$ Sources vary on how many Americans were active in Afghanistan in the 1980s. J.M. Berger has identified at least thirty cases of Americans participating in the Afghan jihad, some of whom continued onwards to other conflicts, and others who returned to the U.S. ${ }^{22}$

Some individuals from this first mobilization in Afghanistan simply moved onwards to the next set of jihadist conflicts, in particular to the civil war in 1990s Bosnia. One example is Christopher Paul, a Muslim convert from the Columbus, Ohio, area who participated in al-Qaeda training camps in Afghanistan during the late 1980s and early 1990s, and later joined the foreign fighter brigades active on the Bosnian Muslim

"Some estimates place the number

of U.S. persons involved in overseas jihadist movements from 1980 to 2011 at more than a thousand."
Pakistan became the preferred destination for jihadist travelers seeking to join al-Qaeda's main corpus of fighters in South Asia. The 2001 U.S. military engagement in Afghanistan forced al-Qaeda to relocate its infrastructure to Pakistan. ${ }^{29}$ From 2007 onward, Somalia outpaced Pakistan as the primary destination for travelers. ${ }^{30}$ One other conflict zone of note is Yemen, where two powerhouses of the American jihadist scene made their mark on anglophone jihadist recruitment networks. The New Mexico-born cleric Anwar al Awlaki, already well-known for preaching jihad on both sides of the Atlantic, traveled to Yemen in 2004 and joined al-Qaeda in the Arabian Peninsula (AQAP). ${ }^{31}$ Together with another American, Samir Khan, the two created the AQAP magazine Inspire, which became formative in radicalizing future decades of English-speaking jihadists. ${ }^{32}$

Three phenomena from these pre-Syria mobilizations of American travelers may help shed light on the dynamics characterizing the current wave of travelers. First, as is the case now, a significant proportion of jihadist travelers to Afghanistan, Bosnia, Pakistan, Somalia, and Yemen appeared to have done so in connec- side of the civil war. ${ }^{23}$ At the conclusion of the conflict in Bosnia, Paul traveled through Europe and made a number of connections with al-Qaeda cells. He subsequently returned to the U.S. and attempted to recruit his own network of jihadist supporters in Columbus. ${ }^{24}$ After almost two decades of participating in jihadist movements in numerous countries, Paul was arrested by the FBI in $2007 .^{25}$

A 2014 RAND study identified 124 Americans who traveled or attempted to travel overseas to join jihadist groups after September 11, 2001. ${ }^{26}$ Almost one-third were arrested before reaching their destinations, and approximately $20 \%$ were reportedly killed overseas. ${ }^{27}$ The most popular destination for jihadist travelers was Pakistan (37 cases), followed closely by Somalia (34 cases); al-Qaeda and al-Shabaab were the two most popular jihadist groups. ${ }^{28}$ tion with networks-close communities, friendship and acquaintance groups, and families. ${ }^{33}$ Cases of attacks in the U.S. perpetrated by individuals who returned from jihad overseas are very rare. The RAND study found that $90 \%$ of the jihadists in the survey were either arrested in the U.S. prior to traveling, killed or arrested overseas, or arrested directly after returning home. ${ }^{34}$ In their sample, 9 of the 124 travelers returned to the U.S. and planned attacks-none of these plots came to fruition or resulted in any deaths. ${ }^{35}$

These two factors point to the third and likely most important phenomenon: the individuals who have been most influential in recruiting American jihadists are those who act as "links" between the various mobilizations. These are the individuals who, upon conclusion or dispersal of a conflict, move onwards to the next battlefield and form connections between 
their old networks and new networks. Ideologues like AQAP cleric Anwar al-Awlaki, whose work on "lone actor jihad" survived his death, have their works re-purposed to recruit individuals during later mobilizations. Operatives like Christopher Paul use skills that they learn in their previous experience with jihad to facilitate plots worldwide. Recently, "virtual entrepreneurs" like the Somalia-based al-Shabaab member Mohamed Abdullahi Hassan (aka Mujahid Miski), use the internet to actively facilitate the travel of U.S. persons to multiple battlefields across the globe. These transitionary figures often act as nodes for recruitment of their fellow Americans back home either for the purpose of conducting attacks or traveling to the latest jihadist hotspot.

\section{How Do American Jihadist Travelers Compare to Other Western Counterparts?}

American and European jihadist travelers tend to differ in numbers, demographic profiles, and means of recruitment. The American contingent is far smaller than those of most European countries. It is estimated, for example, that more than 900 jihadist travelers have left from France, 750 each from Germany and the UK, and over 500 from Belgium. ${ }^{36}$ Although the proportion of travelers to total population and Muslim population are different, in sheer numbers the mobilization from the U.S. more closely compares to the phenomena in countries like Spain (around 200) and the Netherlands (220). ${ }^{37}$

Three major factors explain the smaller American mobilization. Geographic distance between the U.S. and the Syrian/Iraqi battlefields plays a role. The increased length of the journey that would-be American travelers must take to reach Syria allows opportunities for law enforcement to interdict jihadists.

Secondly, the U.S. legal system has multiple tools at its disposal to prosecute jihadist travelers. At the outset of the Syria-related mobilization of jihadist travelers, many European countries did not have laws criminalizing travel. In the U.S., traveling to a foreign country in pursuit of joining a designated foreign terrorist organization (FTO) has constituted a federal criminal offense under the material support statute (18 USC $\S 2339 \mathrm{~A}$ and 2339B) since its adoption in the mid1990s. ${ }^{38}$ Historically, this law has been interpreted broadly (e.g., providing one's self, in the form of travel, to a designated FTO is classified as material support). Prosecutors are given substantial leeway, and those tried under the statute are almost always convicted. ${ }^{39}$ Currently, IS-related material support prosecutions in the U.S. have a $100 \%$ conviction rate. ${ }^{40}$ Moreover, those convicted of material support in the U.S. can face prison sentences of up to 20 years and a lifetime of post-release supervision. In Europe, a much smaller percentage of travelers have been prosecuted. Even in cases where prosecution is successful, convicted travelers face shorter sentences. ${ }^{41}$

Finally, wide-reaching jihadist recruitment networks were far more established in the European context prior to the conflicts in Syria and Iraq. Militant Salafist groups, including al-Muhajiroun in the UK, Sharia4 in several European countries, Profetens Ummah (PU) in Norway, and Millatu Ibrahim in Germany, were all active in several European cities before 2011. When the Syrian conflict began, these groups began to mobilize their supporters to engage in networked travel to the Middle Eastern theater to participate in jihadist movements. ${ }^{42}$ In assessing the stories of European jihadist travelers from these countries, many were active members of these groups prior to leaving. Similar initiatives existed in the U.S. (for example, Revolution Muslim), but they were not organized on the same scale as their European counterparts. ${ }^{43}$

The impact of geographic distance, the legal landscape, and organized Salafi-jihadist networks before the Syrian conflict not only manifested in the increased numbers of travelers from Europe, but also affected a difference in how and from where travelers were recruited. In the American context, a significant percentage of individuals travel in small numbers-at most, two or three from a specific city or neighborhood. Some do so by themselves without any network or connections prior to their departure. In contrast, many of the major hubs of European recruitment, including cities, towns, and even small neighborhoods, are home to dozens of foreign fighters

8| THE GEORGE WASHINGTON UNIVERSITY PROGRAM ON EXTREMISM 
apiece. ${ }^{44}$ In the U.S, particular areas may exhibit similar clustering (Minneapolis and St. Paul, Minnesota, may be a rudimentary case), but none exist on the scale of their European counterparts.

This relative lack of face-to-face contact with jihadist recruitment networks helps explain both the lower numbers of American IS travelers and the role of the internet in inducing Americans to travel. Case studies of many of the individuals included in this dataset reveal that in lieu of personal ties to fellow jihadist supporters in the U.S., travelers used online platforms to make connections throughout the world. ${ }^{45}$ There are a few notable caveats.
First, this is not to suggest that online recruitment was the only factor motivating American jihadists. In many cases, however, access to online networks exacerbated the impact of personal circumstances and connections. The upper echelon of American travelers-those who traveled to Syria, established themselves in the operations of jihadist groups, and then turned homeward to recruit other Americans-usually relied on previous personal networks to facilitate their travel. While these individuals used the internet to communicate with friends, family, and potential supporters in the U.S., there is little evidence to suggest that online propaganda played as large of a role as it did in motivating loners. 



\section{Methodology and Statistics}

$\mathrm{T}$ he authors collated the sample of 64 American jihadist travelers during a multi-year investigation, utilizing a range of sources. These include thousands of pages of documents from U.S. District Court cases. Some of the court filings presented in this study were unsealed following legal and open-access requests made by the Program on Extremism. The Program submitted more than a dozen Freedom of Information Act (FOIA) requests and six appeals to initial rejections of those requests. In addition to the FOIA process, the Program filed several motions in federal courts across the country to enjoin the release of records. As a result, the authors obtained hundreds of pages of previously sealed documents. ${ }^{1}$

This report also presents data gathered from social media accounts that are confirmed to belong to American travelers. These accounts were drawn from the Program on Extremism's database of over 1,000,000 Tweets, from over 3,000 English-language pro-IS Twitter accounts.

Finally, the authors conducted in-person interviews with U.S. prosecutors, national security officials, defense attorneys, returned American travelers, and their families. These discussions provide insight into the radicalization and recruitment processes, travel patterns, and networked connections of American travelers.

As some of the travelers interviewed were defendants in criminal proceedings, authors took multiple safeguards in presenting information from those interviews in this report. Where necessary, the names of interview subjects were redacted or changed to protect anonymity and privacy.

The principal researchers are well-aware of the significant methodological issues presented by interviewing returned jihadist travelers. In presenting interview data, this report relies on previous studies where researchers interviewed travelers to understand the motivations and factors behind their travel. ${ }^{2}$

At the same time, it attempts to avoid the methodological missteps that many studies and media reports have made in transmitting data drawn from interviews with current or former violent extremists. ${ }^{3}$

In the areas of this study that present material gleaned from interviews with travelers, the authors attempt to introduce but heavily qualify statements made by the traveler, explain the complexities in first-person accounts of radicalization and mobilization, and limit potential inferences. Each interview shows that the decision to travel is often opaque, multivariate, and non-generalizable.

Some interviewed travelers returned to the U.S., and since their return, have either pleaded guilty or been convicted by trial of terrorism-related offenses. Convictions can serve as a check on self-serving information, but also introduce other methodological problems.

On one hand, U.S. federal investigators and law enforcement can corroborate aspects of travelers' stories during court proceedings. Also, if travelers are already cooperating with law enforcement, they have little incentive to lie directly about their motivations for traveling or their activities in Syria and Iraq.

On the other hand, if they are awaiting sentencing, they can inflate or deflate aspects of their actions in the hope of receiving more lenient treatment. In any event, the authors made a considerable attempt to qualify the statements made by travelers that are presented in this report.

From this material, the list of travelers was narrowed down to a sample, using several selection criteria highlighted below. This report codes travelers using demographic variables: age; gender; state of origin; current presumed status; U.S. citizenship/permanent 
resident status; whether they had been apprehended or prosecuted; and whether they returned to the U.S.

Using these factors, combined with investigations into their travel and role in jihadist groups, the authors classified travelers (where possible) into one of three categories: pioneers, networked travelers, and loners.

\section{Definitions}

This report defines "American jihadist travelers" as U.S. residents who traveled to Syria and/or Iraq since 2011 and affiliated with jihadist groups active in those countries. An additional selection criterion requires sample subjects to have a legal name. Each aspect of this definition is explained below.

\section{U.S. Residents}

The sample includes U.S. citizens, U.S. permanent residents, temporary and unlawful residents of the U.S., and other individuals with substantial ties to the U.S. The term "American" is often used throughout this report to refer to these individuals.

\section{Travel to Syria and Iraq}

In order to be included in the sample, Americans must have successfully traveled to Syria or Iraq to join jihadist groups from 2011 onward.

The authors chose 2011 as the starting point as it marked the beginning of protests against the regime of Bashar al-Assad in Syria and the formal start of the armed insurgency against al-Assad and the Syrian Arab Republic. ${ }^{4}$ More importantly, 2011 marked the arrival of the first foreign combatants in Syrian jihadist groups. ${ }^{5}$

Since 2011, at least 50 Americans have been arrested for attempting to join IS overseas, with at least 30 more attempting to join other jihadist groups. ${ }^{6}$ Attempted, but unsuccessful travelers are not included in the sample. The traveler in question must have successfully entered Syrian or Iraqi territory.
With the recent decline of IS territory in Syria and Iraq, American travelers have explored other areas as potential destinations for jihadist travelers. ${ }^{7}$ There are documented instances of American jihadist travelers to several other countries, including Yemen, Libya, Somalia, and Nigeria. However, these cases are not included in the sample.

\section{OTHER DESTINATIONS}

From 2011 onward, Syria and Iraq were the preferred destinations for travelers. However, there are notable cases of American jihadists who chose other destinations.

Mohamed Bailor Jalloh, a Virginia resident, traveled to West Africa in June 2015. During his trip, he contacted IS members active in the region and planned to travel onward to join IS in Libya. However, he did not make the journey. Instead, he returned to Virginia and was arrested after planning an attack on members of the U.S. military.

Mohamed Rafik Naji, a citizen of Yemen and legal permanent resident of the U.S., traveled to Yemen in 2015 to join the regional IS affiliate. He eventually returned to New York and was in the process of planning an attack when he was apprehended by law enforcement.

Sources: "Affidavit in Support of a Criminal Complaint." 2016. USA v. Mohamed Bailor Jalloh, United States District Court for the Eastern District of Virginia. Case: 1:16-mj-00296. https://extremism.gwu.edu/sites/ extremism.gwu.edu/files/Jalloh\%20Affidavit\%20 in\%20Support\%20of\%20Criminal\%20Complaint.pdf; "Complaint and Affidavit In Support of Arrest Warrant." 2016. USA v. Mohamed Rafik Naji, United States District Court for the Eastern District of New York. Case: 1:16mj-01049. https://extremism.gwu.edu/sites/extremism. gwu.edu/files/Naji\%20Complaint\%2C\%20Affidavit\%20 in\%20Support\%20of\%20Arrest\%20Warrant.pdf. 


\section{Association with Jihadist Groups}

In order to be included in the sample, a traveler must have either:

- associated with a U.S. designated FTO that ascribes to Salafi-jihadist ideology while in Syria and $\operatorname{Iraq}^{8}$ or,

- associated with a non-designated militant group that ascribes to Salafi jihadist ideology.

The authors use Quintan Wiktorowicz's definition of Salafi jihadist groups, namely, organizations that "[support] the use of violence to establish Islamic states." This interpretation directly applies to the two bedrock organizations of the global Salafi-jihadist movement, al-Qaeda (AQ) and the Islamic State (IS). Both groups, despite differences in how, when, and where violence is considered permissible, extensively use force in pursuit of establishing a system of Islamic governance in the territory they control. ${ }^{10}$

Since 2011, a seemingly endless number of jihadist organizations have been established in Syria or Iraq. Two designated organizations are especially dominant. The Islamic State (IS) initially emerged from the framework of AQ's affiliate in Iraq (AQI), but gradually separated from AQ's central leadership. In June 2014, Abu Bakr al-Baghdadi declared the re-establishment of the Caliphate. ${ }^{11}$

Meanwhile, AQ's regional affiliate in Syria continued operations under the banner of the central leadership. This subsidiary has gone by several different names, but most sources refer to it by its original name, Jabhat al-Nusra (JN). Under the leadership of Abu Mohammad al-Julani, the organization underwent a de jure separation from AQ's central leadership in 2016, and renamed itself Jabhat Fateh al-Sham (Front for the Conquest of the Levant). ${ }^{12}$ As all of the American travelers in the sample who aligned with AQ's affiliate did so while it was still called Jabhat al-Nusra, the authors refer to the group throughout the report using this name.

A third group represented in the sample is Harakat Ahrar al-Sham al-Islamiyya (The Islamic Movement of the Freemen of the Levant, known commonly as Ahrar al-Sham). Ahrar al-Sham is an umbrella organization for dozens of Salafist and Islamist battalions operating in Syria. ${ }^{13}$ Unlike AQ, IS, and JN, it is not a U.S. designated terrorist organization. Specific battalions within Ahrar al-Sham associated with the Free Syrian Army (FSA), which at various points in time has received support from the U.S.-led coalition. ${ }^{14}$

However, as Hassan argues, while Ahrar al-Sham has slightly different positions on specific tactics and methods than AQ, IS, or JN, "people in rebel-held Syria still see Ahrar al-Sham as it is, as a jihadist organization ... the apple has not fallen far from the tree."15 The group also utilizes violence towards the goal of constructing Islamic governance. ${ }^{16}$ Thus, this report considers Americans who associated with Ahrar al-Sham to have joined a jihadist group in Syria.

Association is defined broadly in this report. It includes documented evidence of an individual participating in a range of activities for a jihadist group, including directly fighting for the group, attending a group's training camp, participating in military operations alongside the group, providing funding or services to the group, or other activities covered under the material support statute. ${ }^{17}$

The sample excludes Americans who have traveled to Syria and Iraq and affiliated with other militant groups or designated FTOs that are not Salafi-jihadist. For instance, there are reports of U.S. persons or residents fighting alongside a litany of Kurdish militant organizations (for example, with Yekineyên Parastina Gel, also known as the YPG or People's Protection Units), ${ }^{18}$ with the Free Syrian Army (FSA), ${ }^{19}$ and militant organizations affiliated with the Syrian regime. ${ }^{20}$ These travelers are not included in the sample unless there is evidence that they assisted or associated with jihadist formations during their time abroad.

\section{Legal Name}

Propaganda material and bureaucratic forms released by jihadist groups in Syria and Iraq identify several individuals as "Americans." With rare exceptions, this material does not list travelers by their real, legal names. 
Instead, they default to using the traveler's kunya, or Arabic nom du guerre.

The traditional term used to identify Americans is al-Amriki (the American). In some cases, a traveler identified in jihadist material as al-Amriki could be cross-listed with the legal names of American travelers and identified. For example, Abu Hurayra al-Amriki was found to be the kunya of Moner Abu-Salha. Abu Jihad al-Amriki referred to Douglas McCain. ${ }^{21}$ Zulfi Hoxha adopted the kunya Abu Hamza al-Amriki. ${ }^{22}$

However, some American travelers chose other kunyas based on their individual ethnic backgrounds. Talmeezur Rahman, a native of India who attended university in Texas, went by Abu Salman al-Hindi (the Indian). ${ }^{23}$ Alberto Renteria, a Mexican-American who grew up in Gilroy, California, took the kunya Abu Hudhayfa al-Meksiki (the Mexican). ${ }^{24}$

In at least ten cases, the authors found individuals who were identified as "al-Amriki." However, absent a connection to a legal name, these cases could not be included in the sample. The designation al-Amriki, while commonly used to refer to Americans, is used to refer to individuals with other nationalities who may not have any connection to the U.S. ${ }^{25} \mathrm{~W}$ ithout a link to a legal name, individuals could potentially be included twice in the dataset, once by their legal name and once by their kunya.

Finally, in the cases without a legal name, it was incredibly difficult for researchers to uncover essential demographic information about the traveler in question. Therefore, these individuals were excluded from the sample.

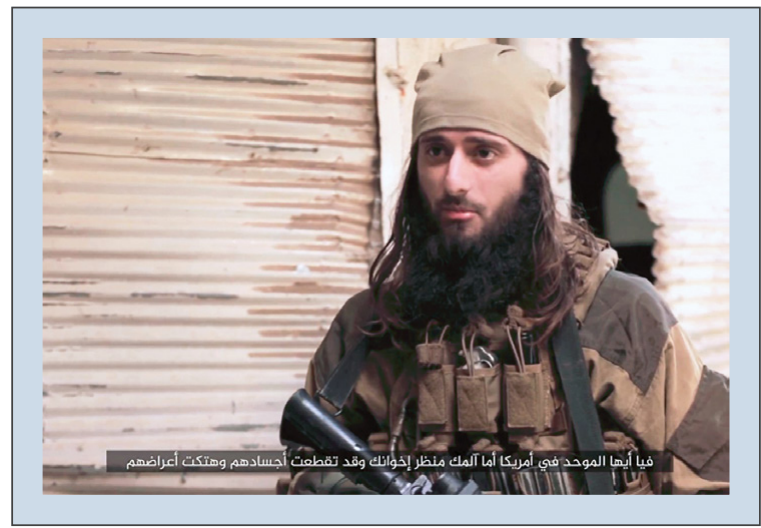

Abu Hamza al-Amriki (Zulfi Hoxha), appearing in "We Will Surely Guide Them To Our Ways," a May 2017 video from IS' Ninawa province in Iraq.

\section{UNIDENTIFIED “AL-AMRIKI”}

Several individuals identifying themselves as "al-Amriki" have appeared in jihadist propaganda material since 2011. Many are not mentioned in this report, as the authors could not verify their true names or details about their stories. Notable examples include:

- Abu Muhammad al-Amriki famously appeared in a February 2014 IS video, criticizing the leaders of JN and explaining his decision to defect from the group to join IS. Speaking in heavily-accented English, he claimed to have lived in the U.S. for over 10 years. His real name and status in the U.S. are unclear, but due to his social media activity and connections in Syria, he was assessed to be a native of Azerbaijan. He was reportedly killed in January 2015.

- In March 2015, IS claimed that one of its militants, Abu Dawoud al-Amriki, conducted a suicide bombing in the Iraqi town of Samarra against Iraqi troops and Shi'a militia groups. He was the first reported American to conduct a suicide attack on behalf of IS.

Sources: Lonardo, David. 2016. “The Islamic State and the Connections to Historical Networks of Jihadism in Azerbaijan." Caucasus Survey 4 (3):239-60. https://doi.org/10.1080/23761199.2016.1221218; al-Bayan radio news bulletin, March 2, 2015. 


\section{THE TRAVELERS}

ABDUL AZIZ, Ahmad Hussam al-Din Fayeq ABOOD, Bilal

ABOUSAMRA, Ahmad

ABU SALHA, Moner

ADEN, Abdifatah

AHMED, Abdifatah

AL-HAYMAR, Ridwan

ALI, Arman

ALI, Omar

AL-JAYAB, Aws Mohammed Younis

AL-KAMBUDI, Sari Abdellah

ALLIU, Erius

AL-MADIOUM, Abdelhamid

AL-MOFLIHI, Ahmed

BAH, Mamadou

BHUIYA, Mohimanul

BRADLEY, Ariel

CLARK, Warren

COOK, Umar

DEMPSEY, Brian

DENNISON, Russell

DOUGLAS, Robert

EL-GOARANY, Samy

FAZELI, Adnan

GARCIA, Sixto Ramiro

GEORGELAS, John

GEORGELAS, Joya "Tania”

GREENE, Daniela

HARCEVIC, Haris

HARROUN, Eric

HOXHA, Zulfi

IBRAHIM, Amiir Farouk
INGRAM, Terry

ISMAIL, Yusra

JAMA, Yusuf

KANDIC, Mirsad

KARIE, Hamse

KARIE, Hersi

KATTAN, Omar

KHAN, Jaffrey

KHWEIS, Mohamad Jamal

KLEMAN, Kary Paul

KODAIMATI, Mohamad

KODAIMATI, Mohamad Saeed

KODAIMATI, "Rahmo"

MAMADJONOV, Saidjon

MANSFIELD, Nicole Lynn

MASHA, Mohamed Maleeh

McCAIN, Douglas

MOHALLIM, Hanad Abdullahi

MOHAMUD, Abdirahman Sheik

MUHAMMAD, Saleh

MUTHANA, Hoda

NASRIN, Zakia

NGUYEN, Sinh Vinh Ngo

NIKNEJAD, Reza

NUR, Abdi

PAZARA, Abdullah Ramo

RAHMAN, Talmeezur

RAIHAN, Rasel

RENTERIA, Alberto

ROBLE, Mohamed Amiin Ali

SHABAZZ, Sawab Raheem

SHALLCI, Sevin 


\section{AMIERICAN JIELADIST T'RAVELERS}

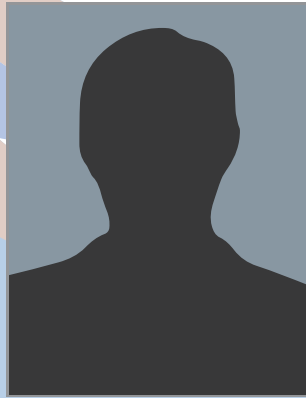

Identified American

jihadist travelers*

Average age at time of travel

U.S. states of origin

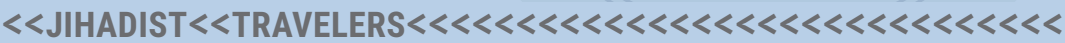

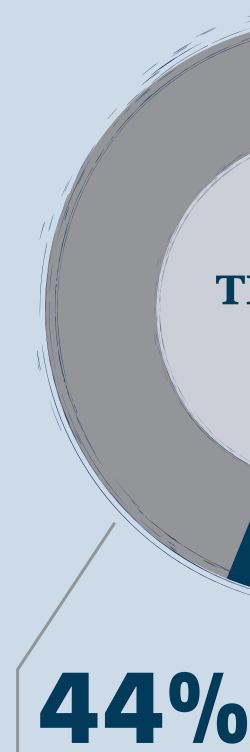

are still at large or their status is publicly unavailable

TRAVELER STATUS

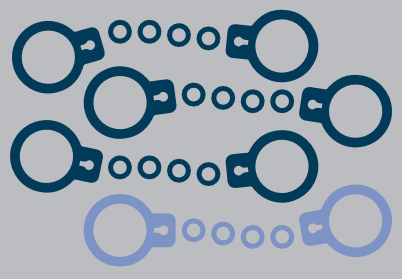

\section{$75 \%$}

of the 12 travelers who returned to the U.S. were arrested and charged.

*AMERICAN JIHADIST TRAVELERS: Americans who traveled to Syria and/or Iraq since 2011 and affiliated with jihadist groups active in those countries.
$89 \%$

are male

More than

$70 \%$

were U.S. citizens

or permanent residents

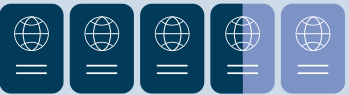

States with the highest rates of travel are:

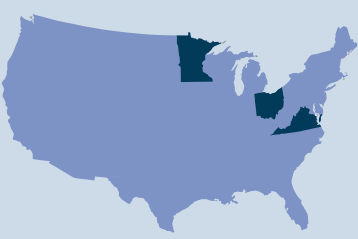

1. Minnesota

2. Virginia

3. Ohio
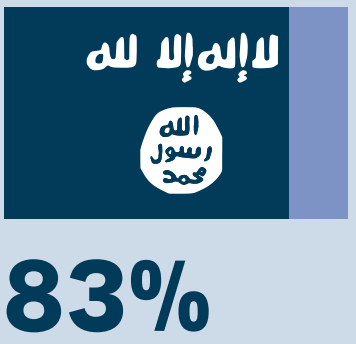

affiliated with the Islamic State upon arrival

The remainder affiliated with other groups. 


\section{Statistics}

This sample of 64 jihadist travelers comprises a range of ages, ethnic backgrounds, states and cities of origin, group affiliations, and socio-economic statuses.

- The average age at time of travel was around 27 years of age.

- $89 \%$ of the dataset are men.

- At least $70.4 \%$ were U.S. citizens or legal permanent residents prior to departure.

- Travelers came from 16 different states; the states with the highest rates of travelers are Minnesota, Virginia, and Ohio.

- Upon arrival in Syria, 82.8\% affiliated with the Islamic State (IS), while the remainder (17.2\%) affiliated with other jihadist groups.

- 22 travelers (34.4\%) are believed to have died in Syria. $12(18.8 \%)$ were apprehended in the U.S. or overseas, and $3(4.7 \%)$ returned to the U.S. without facing charges.* 28 travelers $(43.8 \%)$ are at large, or their status and whereabouts are publicly unavailable.

- 12 travelers (18.7\%) returned to the U.S. The majority (75\%) of returned travelers were arrested and charged.

* One traveler returned to the U.S. from Syria and did not face public charges. Later, he went back to Syria, where he conducted a suicide bombing attack.

\section{Demographics}

Within the sample, the average age that a traveler embarked on their journey to Syria and Iraq was 26.9. ${ }^{26}$ The youngest travelers in the dataset were 18 years old. Minor travelers, whose identifying information is sealed, meaning that it is not made available to the public, are not included in the sample. The youngest, Reza Niknejad, went to Syria and joined IS shortly after his 18th birthday, with the assistance of two high school classmates who were eventually tried as adults for assisting him. ${ }^{27}$

On the other end of the spectrum, the oldest American traveler with a known age was 44 when he traveled to Syria. ${ }^{28}$ Kary Kleman, a Floridian, claimed that he migrated to Syria to participate in "humanitarian" activities, later realizing that what led him to Syria was a "scam." ${ }^{29}$ Kleman surrendered to Turkish border police in 2017; he was promptly arrested on charges that he fought for IS. His extradition to the U.S. is pending. ${ }^{30}$

A majority of the travelers in the sample (70.4\%) were U.S. citizens or legal permanent residents. Furthermore, two travelers were granted refugee status in the U.S. before departure, and another was studying in the U.S. under a student visa. Sixteen cases (25\%) involve an individual whose residency status could not be determined.

Men comprise $89 \%$ of the sample. However, in assessing the gender breakdown of American jihadist travelers, it is essential to consider potential methodological barriers. Samples of Western travelers may underestimate the number of women, particularly those that draw largely from publicly available data. Women jihadists are more likely to avoid detection and apprehension than their male counterparts, and are possibly underrepresented in datasets as a result. ${ }^{31}$ In this report's sample, the seven cases (11\%) of American women jihadist travelers are important for assessing the overall mobilization. This number may not reflect the extent of American women's participation in jihadist groups in Syria and Iraq. Studies of European travelers have found higher percentages of women travelers. A 2016 study of all Western travelers found that around 20\% were women, but in some countries, women represent as much as $40 \%$ of the contingent. ${ }^{32}$

One of the earliest known American cases of jihadist travel to Syria or Iraq was Nicole Lynn Mansfield, a 33-year-old from Flint, Michigan, who left for Syria in 2013. Mansfield, a convert to Islam, was the first American to have been killed in Syria. ${ }^{33}$ She was shot and killed during a confrontation with Syrian government forces in the Idlib province in May 2013. ${ }^{34}$ There are multiple conflicting accounts of which jihadist group she was affiliated with at the time of her death: Syrian government sources claim she was fighting for JN and was killed after throwing a grenade at Syrian soldiers. Ahrar al-Sham also claimed her as a member. ${ }^{35}$ 
In November 2014, 20-year-old Hoda Muthana (kunya: Umm Jihad) left her hometown of Hoover, Alabama, for Syria. Prior to her departure, she was active in the community of English-speaking IS supporters on Twitter and other social media sites, and continued her online presence after arriving in Syria. ${ }^{36}$ Reports at the time suggested that she likely lived in the city of Raqqa with a notable cluster of Australian IS supporters, including her husband, Suhan Rahman (Abu Jihad al-Australi). ${ }^{37}$ Ninety days after their marriage, Rahman was killed in a Jordanian airstrike. ${ }^{38}$ Muthana's current status and whereabouts are unknown. ${ }^{39}$

Zakia Nasrin, her husband Jaffrey Khan, and her brother Rasel Raihan all entered Syria through the Tal Abyad border crossing in the summer of $2014 .{ }^{40}$ Nasrin

\section{AMERICAN CHILDREN IN SYRIA AND IRAQ}

Minors are excluded from the sample. However, there is evidence that some American children traveled to Syria or Iraq alongside their families. Some, including Zakia Nasrin and Jaffrey Khan's daughter, were born in jihadist-controlled territory.

In 2017, a 15-year-old Kansas teenager escaped IS-held territory after living there for five years. She left the U.S. with her father and traveled to Syria. There she married a IS fighter, and was pregnant with his child when she escaped. Additionally, IS released a video in August 2017 that depicted an unnamed young boy in jihadist-held territory making threats against the U.S. In the video, the boy claimed to be an American citizen.

Sources: “We Were Prisoners': American Teen Forced into ISIS Speaks.” 2017. CBS News. October 11, 2017. https://www.cbsnews.com/news/american-teenforced-into-syria-by-father-escapes-isis-in-raqqa; Dilanian, Ken, and Tracy Connor. 2017. "The Identity of the 'American' Boy in an ISIS Video Is Still a Mystery." NBC News. August 24, 2017. https://www.nbcnews. com/news/us-news/u-s-trying-identify-american-boyisis-video-n795691. is a naturalized U.S. citizen born in Bangladesh. ${ }^{41}$ Shortly after graduating from high school, she married Khan, whom she met online. Her friends noted her increasingly conservative behavior following her marriage. ${ }^{42}$ Following arrival in Syria, Khan and Nasrin had a daughter. Nasrin allegedly worked as a doctor in a Raqqa hospital controlled by IS. ${ }^{43}$ Rasel Raihan was killed in Syria; Nasrin and Khan's statuses remain unclear. ${ }^{44}$

Despite the small sample size, American jihadist women travelers help shed light on Western women's participation in jihadist networks. The three women above, alongside others in the sample, defy conventional stereotypes about how and why women (especially Western women) participate in jihadist movements. Although many presume that female jihadists are duped into participation, and motivated by the personal pursuit of love or validation, their contributions and motivations for engagement vary as much as their male counterparts. ${ }^{45}$ Though often relegated to support roles, women's more "traditional" efforts as the wives and mothers of jihadists are not necessarily passive either. American women were committed to the jihadist cause and decided to travel on their own accord. They also appear to have played significant roles in their respective jihadist organizations. ${ }^{46}$ Muthana highlights the role of Western women in networks of online jihadist supporters, Nasrin served in a critically important and understaffed non-combat position (in a hospital), and Mansfield may have been more directly involved in operations.

\section{Geography}

The sample includes travelers from 16 states. It is paramount to assess total figures alongside the rate of recruitment in proportion to the total population. The rates used in this report are generated by taking the number of travelers from a state or metropolitan statistical area and dividing them by either the total population of the state or the Muslim population in the state. ${ }^{47}$ To provide a more accurate sample, these figures are then multiplied by 100,000 (for the total population rate) and 1,000 (for the Muslim population rate), resulting in estimates of how many jihadist travelers in Syria and Iraq 
from a particular state there are for every 100,000 people and 1,000 Muslims in the state. Finally, states with less than two travelers are not included to avoid inferences from incomplete samples. ${ }^{48}$ This method places the issue of jihadist travel in the U.S. in the proper context by using a proportional rate.

Calculated this way, the states with the largest frequency of jihadist travelers per 100,000 people are Minnesota (0.127 travelers), Virginia (0.048 travelers), and Ohio (0.043 travelers). For the rate per 1,000 Muslims, the top three states are Minnesota (0.417 travelers), Missouri (0.171 travelers), and Ohio (0.150 travelers). ${ }^{49}$ The nationwide frequencies, in contrast, are 0.019 travelers per 100,000 people, and 0.018 travelers per 1,000 Muslims. ${ }^{50}$

These rates, compared to the total population and the estimated Muslim population in each state, are infinitesimally small. In sum, these numbers demonstrate that the phenomena of recruitment of jihadist travelers in all states to the battlefields of Syria and Iraq is limited. Unlike in Europe and elsewhere, the phenomenon of traveler recruitment in the U.S. has not been characterized by large-scale networks with deep transnational ties to foreign jihadist groups. Rather, it has been shaped and facilitated by individual kinship- and friendship-oriented groups and, at times, virtual connectivity.

Only seven out of the 16 states in the sample produced more than three jihadist travelers. The states with the highest number of cases are California (13), Texas (9), and Minnesota (7). However, given that the two most populous states in the country represent the highest producers of travelers reveals relatively little about the geographic dimensions of IS recruitment in the U.S.

The authors also utilized a smaller unit of analysis, and evaluated mobilization within particular cities. At this level, rates per capita (due to the low number of travelers from each metropolitan statistical area) are less helpful, but in terms of total count, several metropolitan areas stand out. The areas with the highest frequency of travelers are the Minneapolis-St. Paul and San Diego metropolitan areas, which have seven cases each. The Twin Cities also have the highest proportion of travelers to every 1,000 Muslims in the broader metropolitan statistical area. ${ }^{51}$

These areas are considered anomalies with regard to how many travelers emerged from each metropolitan area, but pale in comparison to recruitment from other Western cities. In the U.S., even when areas like the
Frequency of Travelers by State

\begin{tabular}{|lcccc|}
\hline State & $\begin{array}{c}\text { Number of } \\
\text { Travelers }\end{array}$ & $\begin{array}{c}\text { Travelers per } \\
100,000 \text { people }\end{array}$ & $\begin{array}{c}\text { Travelers per } \\
1,000 \text { Muslims }\end{array}$ \\
\hline California & 13 & 0.033 & 0.048 \\
Texas & 9 & 0.032 & 0.021 \\
Minnesota & 7 & 0.127 & 0.417 \\
Ohio & 5 & 0.043 & 0.150 \\
Florida & 4 & 0.019 & 0.024 \\
Virginia & 4 & 0.048 & 0.019 \\
New York & 4 & 0.020 & 0.010 \\
Missouri & 2 & 0.033 & 0.171 \\
Massachusetts & 2 & 0.029 & 0.092 \\
Michigan & 2 & 0.020 & 0.017 \\
New Jersey & 2 & 0.022 & 0.012 \\
\hline
\end{tabular}

Frequency of Travelers by Metro Area

\begin{tabular}{|lccc|}
\hline Metropolitan Statistical Area & $\begin{array}{c}\text { Number of } \\
\text { Travelers }\end{array}$ & $\begin{array}{c}\text { Travelers per } \\
100,000 \text { people }\end{array}$ & $\begin{array}{c}\text { Travelers per } \\
1,000 \text { Muslims }\end{array}$ \\
\hline Minneapolis-St. Paul-Bloomington (MN-WI) & 7 & 0.197 & 0.495 \\
San Diego-Carlsbad (CA) & 7 & 0.211 & 0.318 \\
Dallas-Fort Worth-Arlington (TX) & 6 & 0.083 & 0.039 \\
Columbus (OH) & 5 & 0.245 & 0.321 \\
New York-Newark-Jersey City (NY-NJ) & 5 & 0.025 & 0.022 \\
Washington-Arlington-Alexandria (DC-VA-MD) & 4 & 0.065 & 0.029 \\
Sacramento-Roseville-Arden-Arcade (CA) & 3 & 0.131 & 0.169 \\
Houston-The Woodlands-Sugar Land (TX) & 3 & 0.044 & 0.022 \\
Flint (MI) & 2 & 0.489 & 0.181 \\
St. Louis (MO-IL) & 2 & 0.071 & 0.169 \\
Tampa-St. Petersburg-Clearwater (FL) & 2 & 0.066 & 0.055 \\
Boston-Cambridge-Newton (MA) & 2 & 0.042 & 0.022 \\
\hline
\end{tabular}


Twin Cities and San Diego produce seemingly sizable traveler contingents, the cases do not usually exhibit the same networked ties between them as seen in European towns and cities.

Nevertheless, further analytical research is necessary to uncover which factors in these American communities make them frequent places of origin of jihadist travelers, in comparison to others. In some cities, most notably the Minnesota Twin Cities, there have been high-profile court cases on American travelers and attempted travelers. This resulted in extensive local investigative journalism that yielded a considerable amount of publicly available information. However, in many other areas, information is scarce.

\section{Status in Syria and Iraq}

Gathering evidence about an individual's activities in Syria and Iraq after leaving the U.S. is a challenging task. In the constellation of militant groups and other organizations active in Syria and Iraq, evidence about which organization an individual traveler affiliated with can be difficult to come across. Adding to this issue, individuals change their affiliations as the landscape of militant groups changes.

To resolve some of these concerns, this study codes travelers in the sample by the last known jihadist group that they participated in based on evidence available to the authors. For some of the travelers in this dataset, it was the group they were affiliated with at the time of their death; for others, it was the last group to which they publicly claimed support. Additionally, for travelers who were subject to federal investigations with available evidence, court records also detail their interaction with FTOs in Syria and Iraq.

A majority of the travelers (82.8\%) are associated with IS. Several started their careers with other jihadist groups, but later joined IS as the organization grew territorially and established itself as a formidable force in Syria and Iraq. The remaining $17.2 \%$ includes travelers who affiliated with JN, Ahrar al-Sham, and other jihadist groups.
The fact that IS enjoyed this level of support within the demographic is unsurprising. In comparison to other jihadist groups in Syria and Iraq, IS relied heavily on travelers to provide assistance to their military campaigns and solidify the ideological narrative that they were attracting Muslims from all over the world to re-establish the historical Caliphate. ${ }^{52}$ In contrast, groups like JN and Ahrar al-Sham were mainly reliant on local Syrian fighters, although before IS' rise to preeminence, they also attracted some travelers in the early stages of the conflict. ${ }^{53}$

The travelers in the sample who did not affiliate with IS generally arrived earlier in the conflict and were killed, captured, or left the conflict before June 2014. Some of the sampled travelers who initially associated with JN or another AQ affiliate also arrived early. If they stayed in Syria or Iraq for a significant period, especially following IS' declaration of the Caliphate in June 2014, they switched affiliations. This would appear to underline another noted shift in how recruitment of travelers to the Syrian and Iraqi conflicts occurred. Early Western travelers were often motivated mainly by joining the armed resistance against al-Assad in defense of the Syrian people; later travelers were more drawn to specific groups, their goals, and their ideologies (notably IS). ${ }^{54}$

The status and current whereabouts of the sampled travelers is more difficult to determine. Without conclusive evidence that an individual traveler has been killed or captured, they are considered in this report to be "at large" (43.8\%). That notwithstanding, death rates for Western travelers have been catastrophic. In early 2017, Western intelligence services estimated that more than half of the travelers from Western Europe and North America died fighting in Syria and Iraq. ${ }^{55}$ Therefore, it is likely that some percentage of individuals who are considered at large were killed, but their deaths went unreported.

The authors found credible evidence that 22 of the 64 sampled travelers (34.4\%) died in Syria and Iraq. The first reported death was Nicole Mansfield on May 29, 2013, but the U.S. government has yet to publicly provide a 
confirmation. Following her case, there were several high-profile deaths of American travelers in the summer and fall of 2014. This includes Douglas McCain, the first U.S. citizen whom the government acknowledged had died fighting for IS. In many cases, the exact date of death for travelers is unknown.

Twelve of the 64 sampled travelers (18.8\%) returned to the U.S. Nine of the 12 were either apprehended overseas and extradited to the U.S. or returned to the U.S. and promptly arrested. Law enforcement has not pressed public charges against the remaining three travelers. In addition to the American travelers who have returned to the U.S., two more participants in the Syrian and Iraqi conflicts within the sample are currently being detained by foreign governments.

\section{Categorization}

Based on a combination of the factors discussed above that shaped why, when, and how an American traveled to Syria and Iraq to participate in jihadist organizations, the authors derived a tripartite typology for American travelers. These categories help provide a useful heuristic for not only American policymakers, but other countries that are facing the problem of jihadist travelers.

This is intended to contextualize the factors shaping jihadist travel and assist in preliminary risk analysis. Developing complex frameworks for responding to jihadist travel is a priority for the U.S. government and many other countries. Using these categories, analysts and policymakers can more accurately determine the type of threat a specific traveler is likely to pose.

These three categories are not mutually exclusive. The networked traveler and loner categories are predicated on the factors that influenced an individual's travel, whereas the pioneer category is mainly based on their role. Thus, while it is not possible for an individual to be a networked traveler and a loner at the same time, pioneers may be either.

The three categories-pioneers, networked travelers, and loners-are defined below, with a statistical breakdown (where possible) of what percentage of the sample they comprise. ${ }^{56}$ Each section provides case studies of individual U.S. travelers within that category, and the relevance of the classification. 



\section{Category 1: Pioneers}

$\mathrm{T}$ his report uses the term "pioneers" to refer to the top-tier of U.S. jihadist travelers in Syria and Iraq. Pioneers arrived early, built connections in jihadist networks, and contacted supporters who were still in the U.S. to encourage them to provide support or join their organizations. These individuals often become nodes of jihadist recruitment in the U.S. and are linked to several other cases of material support and travel.

This subset of cases rarely occurs in the dataset. The overwhelming majority of travelers embarked on their journey in small groups or alone, whereas these individuals travel with the support of more extensive networks. They use their connections and skills to build notoriety, and eventually reach leadership positions in jihadist organizations.

From a definitional standpoint, pioneers usually fit three criteria. First, as the name suggests, pioneers arrived earlier in the Syrian and Iraqi conflicts than many of their counterparts. Travelers who left prior to the rise of IS did not hold the same misconceptions as their later counterparts. Many had a clearer sense that they were going overseas to fight, versus subsequent travelers who may have been convinced that they could serve jihadist organizations in non-combat roles. Pioneers often hit the ground running upon arrival in Syria, nearly immediately participating in military campaigns.

To provide an overview of what this category of traveler entails, the following sections detail the stories of Abdullah Ramo Pazara and Ahmad Abousamra, two examples of pioneers. They highlight the networks they were able to build, both on the battlefields of Syria and back home in the U.S. Despite their differing backgrounds, both men became pioneers of the American jihadist scene in Syria and used their influence in order to further recruitment in the U.S. and elsewhere around the world.

\section{Abdullah Ramo Pazara}

In February 2015, six Bosnian immigrants to the U.S. were charged with providing material support in the form of money, rifle scopes, knives, military equipment, and other supplies to jihadists in Syria and Iraq through intermediaries in Bosnia and Turkey. ${ }^{1}$ A seventh individual, Abdullah Ramo Pazara, was named but not charged in the indictment as one recipient of the material support. ${ }^{2}$ Pazara was described as a Bosnian native who immigrated to the U.S., became a naturalized citizen, and resided in St. Louis, Missouri, before leaving for Syria to fight for IS in May 2013. ${ }^{3}$

Pazara's case drew interest from U.S. government agencies, scholars of terrorism, and the media for numerous reasons. He was one of the first Americans whom the U.S. government publicly acknowledged had traveled to Syria to fight. Digging into his backstory further, news outlets in Bosnia and Herzegovina uncovered that Syria was not Pazara's first military engagement, revealing his service records from the Bosnian Civil War in the mid1990s. ${ }^{4}$ Upon arrival in Syria, he used connections to the dozens of Bosnians already in-theater to climb the ranks of multiple jihadist organizations, eventually ending up as a mid-level commander of an IS tank battalion. ${ }^{5}$ Finally, his requests to his fellow Americans back home from the battlefields in Syria not only included military and tactical equipment, but also more mundane items, including packets of Swiss Miss hot cocoa mix. ${ }^{6}$

The full arc of Abdullah Ramo Pazara's story, from his roots in the former republics of Yugoslavia to his death on the battlefield fighting the PKK in the town of Kobane, reveals the twisting paths that many Americans take in traveling to join jihadist groups overseas. Pazara is the classic example of an American pioneer traveler in Syria: setting up a litany of contacts, distinguishing himself in Syria from other Americans, and reaching back to the U.S. to recruit and mobilize others. 


\section{Motivations}

Ramo Pazara (at this time, he had not adopted the name Abdullah) was born in 1976 in the Socialist Republic of Bosnia and Herzegovina, then a part of communist Yugoslavia. His home village, Gomjenica, is situated on the outskirts of the town of Teslic in an area of Bosnia predominantly inhabited by Orthodox Serbians. In Teslic, a multiethnic and multi-religious municipality, Pazara lived alongside Bosnian Muslims, Orthodox Serbians, and Catholic Croats.

The civil war that tore Bosnia and the rest of Yugoslavia apart disrupted Pazara's adolescence. Teslic's location and multiethnic status made it subject to the ethnic cleansing that occurred during the Bosnian Civil War. In April 1992, the paramilitary forces of the Bosnian Serbs, known as Vojska Republike Srpske or VRS, demanded that Teslic's residents swear allegiance to the VRS. Bosnian Muslim and Croat public officials could join the VRS, or be forced to resign and face the consequences. ${ }^{7}$ In Teslic, the VRS perpetrated dozens of crimes against humanity, including liquidating local Bosnian Muslim political leaders, indiscriminately bombing villages, and establishing concentration camps. ${ }^{8}$

Shortly following his death in Syria, the online newspaper Sloboda Bosna claimed that Pazara fought for the VRS, despite being a Bosnian Muslim. ${ }^{9}$ Several Bosnian expert sources confirmed the existence of these records, which detail that Ramo Pazara joined the VRS at the age of 17 alongside his father and fought in the Pelagicevo region and the towns of Majevica and Bihac. ${ }^{10}$ During the height of the war, in 1994, Pazara served as a sniper for a VRS unit fighting in the Bosnian-Croatian border town of Orasje. ${ }^{11}$

The common assumption is that Pazara's generation of Bosnian Muslim jihadists all have networked ties to the jihadist brigades operating in Bosnia at the time of the civil war. These formations include the infamous $\mathrm{El}$ Mudžahid brigade, in which many individuals (including foreign fighters) who were later connected to al-Qaeda operations in Bosnia and overseas fought during the civil war. Pazara's case is an exception to the rule. As a VRS paramilitary, it is likely that Ramo Pazara fought directly against jihadists during the Bosnian Civil Warthe Bosnian Serb VRS fought, in various circumstances, against the El-Mudžahid brigade, which allied itself with the Bosnian Muslim cause.

In any event, Pazara's experiences during the Bosnian War proved formative to his later life in America, and his eventual travel to Syria to join the fighting there. Firstly, after the civil war ended in 1995, and after Pazara and his father completed their alleged tour of duty for the VRS, they were still not allowed to return to their hometown of Teslic. Returning to Teslic risked their imprisonment, torture, or potential deaths. Ultimately, Pazara and his father were subject to the same ethnic cleansing inflicted on the rest of the Bosnian-Muslim residents. Like other Bosnian Muslim families, the Pazara family was forced into the diaspora.

Pazara's arrival in the U.S. during the late 1990s would have placed him in an immediate conundrum. If Pazara disclosed his participation in the Bosnian Serb Army on immigration forms, as required by law, he could have been subject to prosecution for war crimes or deported to Bosnia. Failing to disclose participation in the VRS on immigration forms is also a potentially prosecutable crime. ${ }^{12}$

Pazara ultimately decided not to disclose his war record on immigration forms, and did not formally apply for citizenship until he had lived for at least fifteen years in the U.S. The concern was likely not only the potential legal consequences of disclosure, but also the backlash from the Bosnian diaspora in America. Many members of the diaspora from Pazara's generation saw their hometowns destroyed and family members killed at the hands of the VRS and other Serb paramilitary forces, forcing them to flee the country. The mere rumor of VRS participation would likely have made Pazara a pariah. Few records of Pazara from the early years of his life in America are publicly available.

Pazara's transition from Bosnian militia sniper to U.S. civilian life was rocky. He settled in Warren, Michigan, and co-founded a commercial trucking company with his then-wife in 2004. Financial records detail the difficulties faced by the Pazaras' company-it registered slim profits and massive debts in the three years that it was 
active. The Pazaras filed for divorce in 2007, with his wife taking control of the trucking company. One year later, Ramo Pazara filed for bankruptcy in the state of Michigan and agreed to forfeit most of his property. ${ }^{13}$ From 2008 to 2011 Pazara maintained addresses in Michigan but spent a considerable amount of time with his relatives in Utica, New York. ${ }^{14}$

It was in Utica where Pazara likely first came into contact with one of the future members of the network that he would eventually reach out to once he arrived in Syria. Nihad Rosic, a much younger Bosnian immigrant, was working as a truck driver by day and a semi-pro mixed martial artist by night in the Utica area. ${ }^{15}$ Rosic's parents and Pazara's brother and sister-inlaw, as documented on social media, had a close relationship.

According to Rosic's attorney in the ongoing trial proceedings, Rosic "turned a corner" in terms of his religiosity around 2011-the same time that Pazara was frequently visiting Utica and began to adopt more conservative beliefs and appearance. ${ }^{16}$ Prior to his arrest for material support, Rosic also had an extensive record of domestic abuse. In 2011, he was arrested and charged with endangering the welfare of a child after punching a woman who

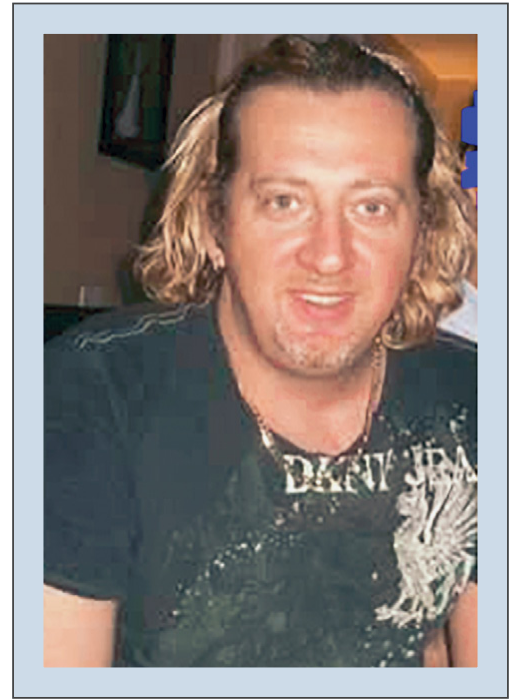

Ramo Pazara in Utica, New York, 2010. the most well-integrated immigrant communities in the U.S. ${ }^{19}$ Although Pazara was living in a large, tight-knit Bosnian community, one local leader later told the St. Louis Post-Dispatch that "nobody" knew him. Despite Pazara's reported embrace of conservative Islam, none of the local imams in St. Louis's many mosques claim to have known him. His landlord and neighbors, while noting his long beard and thawb (traditional Arab robe), claimed that he kept to himself. ${ }^{20}$

Pazara did, in fact, have a small group of friends in the St. Louis area. Many of them shared similar backgrounds, economic difficulties, and recent changes in their religiosity. Among them was Ramiz Zijad Hodzic (nicknamed "Siki"), another former resident of Teslic. Hodzic served on the opposite side of the Bosnian Civil War as Pazara, and eventually won Bosnia's highest military honor (the Golden Lily). ${ }^{21}$ In the mid-1990s, he and his wife Sedina arrived in America as refugees. ${ }^{22}$ Pazara and Ramiz Hodzic shared a hometown, military experience, and less-than-stellar financial records. The Hodzics were over $\$ 300,000$ behind in federal and state taxes, and faced lawsuits for unpaid rent and credit card bills. ${ }^{23}$ Their adoption of conservative Islam also apparently occurred around the time Pazara was carrying a baby in her arms. ${ }^{17}$ Then, in 2012, he served a year-long sentence for beating his wife with a belt in front of their children. The dispute arose when Rosic found a bottle of his wife's perfume in the house, which he interpreted as violating the Islamic prohibition on alcohol-based products. ${ }^{18}$

By the time Pazara moved permanently to St. Louis, Missouri, in late 2011 in search of work, he had already adopted the outward appearance of a committed Salafi believer. The St. Louis metropolitan area is home to over 70,000 Bosnians, the largest diaspora community outside of Europe. The St. Louis Bosnian-American community has frequently been assessed to be one of arrived in St. Louis. The Hodzics' neighbors claimed that they remembered Ramiz frequently attempting to barbecue while drunk and that Sedina started wearing the hijab just a few months before her arrest. ${ }^{24}$

Although publicly available evidence is sparse, Pazara and the Hodzics used the internet and social media to connect with like-minded members of the Bosnian diaspora worldwide. The period between 2011 and 2012, when Pazara moved to St. Louis and connected with the Hodzics, was also the timeframe in which the Syrian conflict began to escalate from its roots in opposition protests to Syrian President Bashar al-Assad to a more globalized engagement involving foreign participants. 
Members of the Bosnian diaspora, many of whom have personal experiences with the plight of civil war, the status of refugees, and ethnic cleansing, were understandably deeply concerned about similar events taking place in Syria. ${ }^{25}$ Unsurprisingly, Salafi-jihadist groups who publish in the Bosnian language used these sentiments to recruit on social media. Using websites like Put Vjernica (Way of the Believer), Vijesti Ummeta (News from the Ummah), as well as popular social media platforms like Facebook, they disseminated material encouraging Bosnians in the diaspora to respond to the plight of Muslims in Syria by joining militant groups. ${ }^{26}$

Pazara was not a particularly observant Muslim prior to about a year or so before his travel to join Salafijihadist groups in Syria, but he also once participated in a paramilitary formation which directly fought, and even committed war crimes against Muslims in Bosnia. Today, however, many Bosnian jihadist supporters in the diaspora are too young to have actively participated in the Bosnian War, and may not have viewed Pazara's alleged participation in the VRS as damning, or even relevant. The only connection that would have mattered was their mutual interest in jihad.

\section{Journey and Network}

Shortly after he became an American citizen in May 2013, Pazara traveled to Syria to fight. ${ }^{27}$ He adopted a new name as part of his naturalization proceedings, and formally became Abdullah Ramo Pazara. ${ }^{28}$ Eleven days later, he traveled to Syria through Zagreb, Croatia, Bosnia, and Istanbul. ${ }^{29}$

Pazara was supposed to go with two others, but only one-Haris Harcevic-made the journey. Nihad Rosic, who remained in touch with Pazara via social media, also intended on traveling to Syria, according to the
2015 indictment. ${ }^{30}$ However, at the time of Pazara's May 2013 journey, he was still imprisoned on the domestic violence charge and could not go. ${ }^{31}$ Several individuals with knowledge of the investigation, as well as border records in Bosnia, confirmed that Harcevic also traveled with Pazara through the Balkans, Turkey, and Syria in summer 2013. ${ }^{32}$ Harcevic, who is included in the study's sample, arrived in Syria, remained only for a short time, and promptly returned to the U.S. ${ }^{33}$ He has not faced any charges in the criminal case against Pazara and his network, although his brother Armin was charged with providing material support.

After Pazara arrived in Syria, his friends in St. Louis, Ramiz and Sedina Hodzic, allegedly began reaching out to online contacts to collect funds and buy supplies for Pazara. From August 2013 to September 2014, Pazara reportedly used Facebook and email to request specific items, coordinate shipments, give updates on his location and status, and share information about the jihad in Syria. ${ }^{34}$

In total, four people (Nihad Rosic, Mediha Salkicevic, Jasminka Ramic, and Armin Harcevic) allegedly sent money to Ramiz and Sedina Hodzic to help buy military equipment and supplies for Pazara and other travelers in Syria. ${ }^{35}$ According to the indictment, the money was used to purchase "U.S. military uniforms, combat boots, military surplus goods, tactical gear and clothing, firearms accessories, optical equipment and range finders, [and] rifle scopes." ${ }^{36}$ The Hodzics allegedly sent the supplies to unnamed individuals in Turkey and Saudi Arabia, who then transferred the materials to Pazara and other Bosnian fighters in Syria and Iraq. ${ }^{37}$ They also allegedly collected funds for the families of Bosnian travelers.

In April 2014, Nihad Rosic purchased a plane ticket to Istanbul for July 20, 2014 after discussing travel to 
Syria with Pazara on Facebook Messenger. ${ }^{38}$ However, when Rosic tried to board Norwegian Airways Flight DY7002 to Oslo, Norway, for the first leg of his journey, he was prevented from flying due to the conditions of his probation..$^{39}$ Rosic's failed voyage to Syria may have tipped off law enforcement to the funding scheme. In February 2015, the U.S. Attorney's Office filed indictments against Nihad Rosic, Ramiz Hodzic, Sedina Unkic Hodzic, Mediha Salkicevic, Jasminka Ramic, and Armin Harcevic. Federal agents arrested all six defendants. ${ }^{40}$
IS' most senior military leader, and the fighters that stayed with him from his JMA days were also given leadership positions.

The JMA split particularly benefited one of Umar al-Shishani's lieutenants, a seasoned Bosnian jihadist named Bajro Ikanovic. Ikanovic had previously spent four years in Bosnian prison after being apprehended during the planning stages of attempting to detonate an explosive device outside of a Western embassy in Sarajevo, on behalf

\section{Pazara in Syria}

According to Vlado Azinovic, Pazara's role in Syria was a mid-level tank and vehicle battalion commander for IS, commanding a unit of about 60 to 70 men. ${ }^{41}$ However, when Pazara first arrived in Syria in the summer of 2013, IS as an organization had not reached the level of notoriety and success that it attained after the declaration of its self-proclaimed caliphate in June 2014. Like many other travelers, Pazara initially fought for a smaller outfit, and as a result of the changes in the political and military landscape in Syria, eventually found his way into IS.

Pazara initially was a member of a jihadist outfit called Jaish al Muhajireen w'al Ansar (The Army of Emigres and Helpers, or JMA). The group largely comprised travelers from the Caucasus, Central Asia, and the Balkan countries who made up the bulk of the group's fighting force. ${ }^{42}$ JMA was led by former members of the mid-2000s jihadist underground in the Caucasus and the Balkans, who, after facing prosecution in their home countries, migrated to Turkey and then onwards to Syria at the outset of the conflict. ${ }^{43}$

JMA has played an outsized role in the intrajihadist competition in Syria. Soon after Pazara's arrival, one of JMA's commanders, Tarkhan Batirashvili (aka Umar al-Shishani), defected to IS. ${ }^{44}$ JMA split, with the bulk of the group's members joining Umar al-Shishani in IS; this cohort included the majority of JMA's Bosnian militants. ${ }^{45}$ Ultimately, Umar al-Shishani became
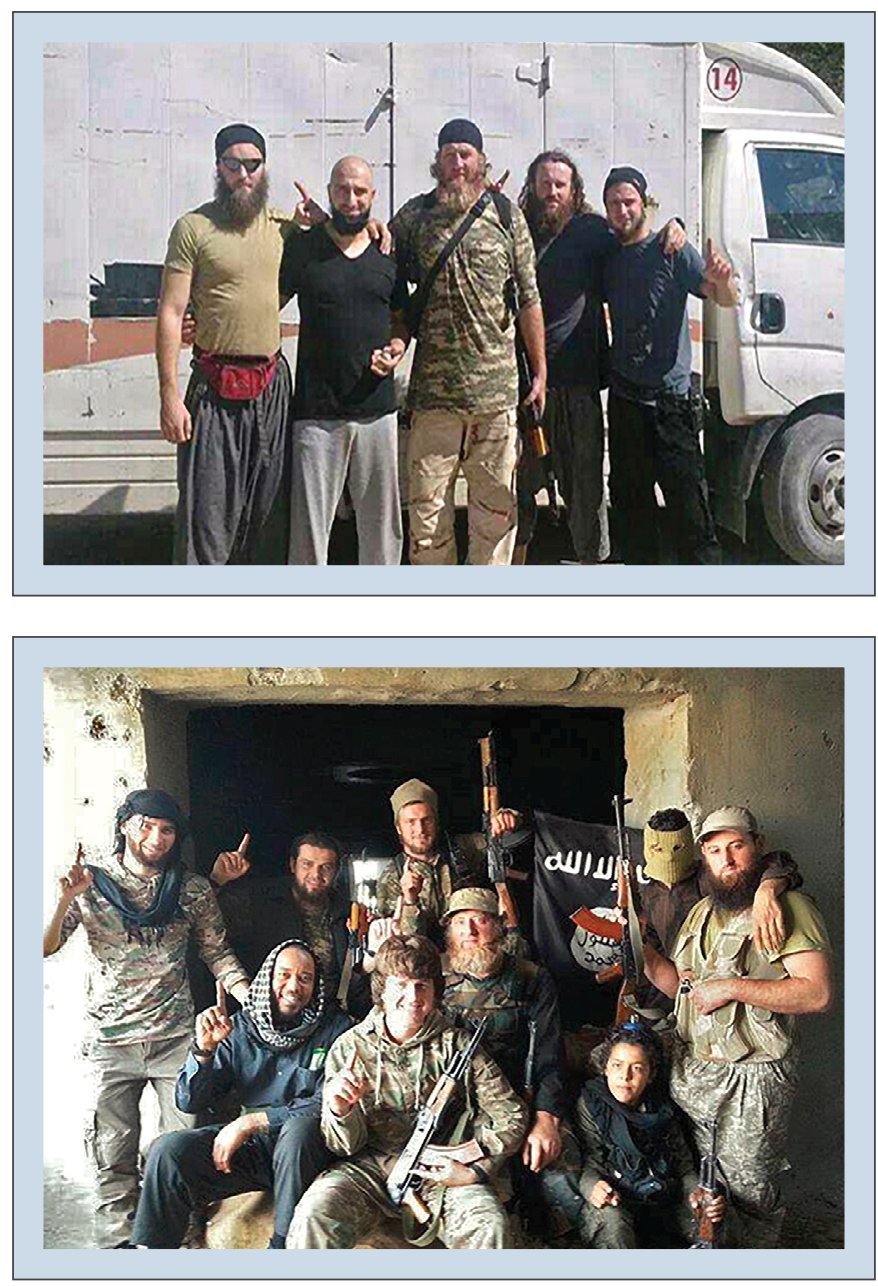

Top: Bosnian jihadists in Syria. L-R: "Amr Ibn Islam," "Ebu Malik el-Sanjaki," Abdullah Ramo Pazara, Bajro Ikanovic, Sejdin Omerovic. Bottom: Jihadists in Syria, including Abdullah Ramo Pazara (seated in second row, center), and German jihadist Denis Cuspert, also known as Deso Dogg (second row, left, with keffiyeh). Cuspert married another American traveler, Daniela Greene. Greene, a former FBI employee, traveled to Syria in 2014. 
of al-Qaeda. ${ }^{46}$ Before his reported death in March 2016, the State Investigation and Protection Agency (SIPA) of Bosnia and Herzegovina considered Ikanovic to be the most dangerous Bosnian citizen in Syria and Iraq. ${ }^{47}$

Ikanovic was sanctioned as a specially designated global terrorist by the U.S. Department of the Treasury in 2015. The designation claims that Ikanovic held various leadership positions in IS, including being a member of the organization's judicial branch for religious-military affairs, the Shura Council, and the head of the largest IS training camp in northern Syria at the popular border-crossing point of Azaz. ${ }^{48}$ In Azaz, Ikanovic "appropriated" a mansion from a former Syrian regime official that was used to transit travelers from the Balkans and elsewhere into Syria.

Another one of Pazara's Bosnian connections in Syria made his name in a completely different, but nonetheless prescient manner. A teenager from the Sanjak region of Serbia, Mirza Ganic (aka Abu Shahid) was in charge of multiple Bosnian online jihadist forums, and was known for his braggadocio and charisma in supporting IS. ${ }^{49}$ Despite his youth and combat inexperience, Ganic's prolific social media presence commanded the respect of a broad swath of Bosnian travelers. His influence apparently extended far into the diaspora. According to court documents, Ramiz Hodzic posted a picture of a combat knife and commented that Mirza Ganic was interested in obtaining the weapon for "slaughtering." ${ }^{50}$ When Ganic was killed in Aleppo in September 2014 at the age of 19, Pazara posted on Facebook:

My brother Abu Shahid was martyred. I pray to Allah to grant him jannah [heaven] and the paradise of Firdaus, and bring him together in jannah with the Prophet of Allah, peace be upon Him. ${ }^{51}$

Most of the available evidence about Pazara's time in Syria comes from his Facebook account. While today, jihadist formations make more active pushes to prevent their fighters from harming their operational security by using social media in-theater, during the early days of the Syrian conflict it was en vogue for travelers to become outsized social media personalities. Pazara's account, under the name Abdullah Ramo Mudzhahid, kept a diary of who he was associating with, daily news from the frontlines, and pictures of himself, his compatriots, and their activities.

The earliest photos on this account depict a more romanticized view of combat, showing Pazara in recruitment-style pictures. Accompanying one image of him posing with a rifle, Pazara commented:
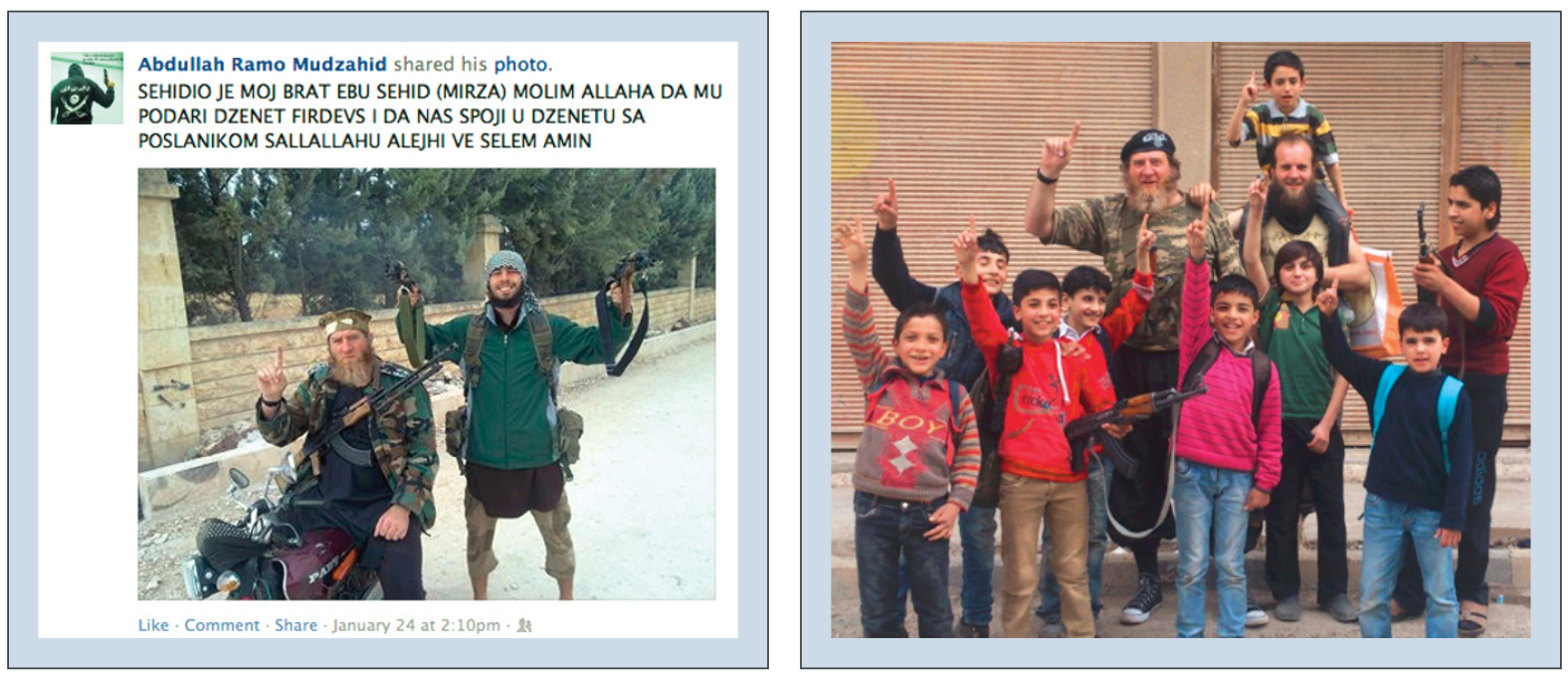

Left: Facebook post from Abdullah Ramo Pazara eulogizing Mirza Ganic. Picture shows Pazara (L, on motorcycle), and Ganic ( $R$, standing). January 24, 2014. Right: Abdullah Ramo Pazara (back left) and Bosnian jihadist "Amr Sham" (back right, with child on shoulders) with Syrian children. 




Facebook post from Abdullah Ramo Pazara in Syria. "I have a strong will, like iron. No, we will not run away, and even if they kill me I will become a martyr. I would love for my brothers felt the sweetness of faith and jihad for just one second, they would immediately be sent to heaven, Allahu Akbar."

I pray to Allah that this picture can be used for da'wa [outreach] ... May Allah give my brothers and sisters even more strength for this job, which leads us on the path to Paradise. ${ }^{52}$

Other images attempt to explain to those outside of IS-controlled territories that their creature comforts from their home countries-including motorcycles and Bosnian-style lamb roasts-would be available if they too joined IS.

However, other pictures show that Pazara was wholeheartedly committed to fighting and combat in Syria. In March 2014, he communicated with an unnamed individual in the U.S. Pazara allegedly told of a mission in which his battalion took control of a large area, killed 11 opposing soldiers, and captured one prisoner. Pazara stated that he intended to slaughter the prisoner the next day. ${ }^{53} \mathrm{~A}$ few weeks later, Ramiz Hodzic, Pazara's friend in St. Louis communicated with Nihad Rosic, Pazara's friend in Utica, New York. Hodzic claimed he saw a video of Pazara's group in action, potentially during the late-March operation Pazara described. Hodzic told Rosic that he saw "ours" (that is, Pazara's group) kill five soldiers, one of whom they beheaded. ${ }^{54} \mathrm{He}$ allegedly used this example to encourage Rosic to donate money to buy "five good snipers," which Rosic allegedly did on April 15, 2014. ${ }^{55}$

In May 2014, Pazara uploaded a photo album of dead Kurdish combatants to his Facebook page, killed fighting Pazara's battalion. "These kafirs [nonbelievers] of the PKK [the Kurdistan Workers' Party] ... with Allah's help, were killed during the last military action fighting against the Islamic State," Pazara proclaimed online. "This is what is waiting for them in the world, these infidels in the trenches were killed one by one fleeing their homes." ${ }^{56}$

Four months later, IS fighters began a siege of the areas surrounding Kobani in the autonomous region

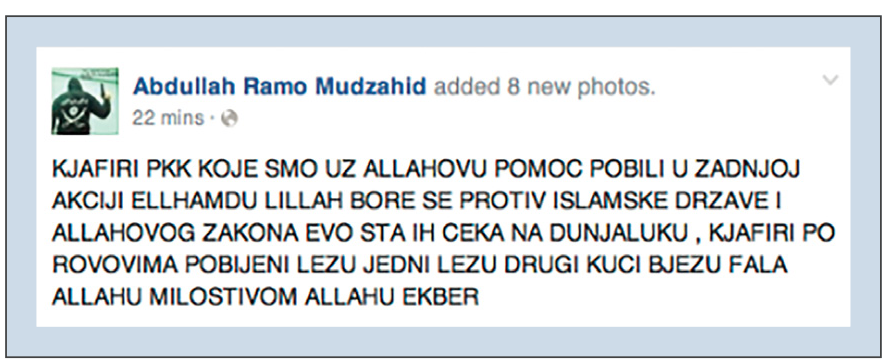

Facebook post from Abdullah Ramo Pazara discussing a battle against PKK fighters. May 2014. 
of Rojava on the Turkish-Syrian border. They faced stiff resistance from a coalition led by Kurdish factions and Iraqi Peshmerga forces, along with elements of the Free Syrian Army. On or around September 22, 2014, Pazara died in battle in Kobani at the age of $38 .^{57}$

To date, Pazara stands as one of the highest-ranked Americans to ever have fought for IS. His combat experience during the Bosnian Civil War, regardless of what side it was for, appears to have helped him navigate jihadist combat in Syria in ways that other American citizens could not. Building on his position, he remained in contact with his networks in the U.S., and attempted to facilitate their material support, and in Nihad Rosic's case, travel to join IS. Abdullah Ramo Pazara is thus a quintessential example of a jihadist pioneer in Syria and Iraq. His story serves as a reminder of how particular Americans, contingent on their abilities and networks, can distinguish themselves from other American travelers.

\section{Ahmad Abousamra}

The eighth issue of IS' official magazine publication, Rumiyah (Rome), released in early April 2017, contained a eulogy for the media propagandist Shaykh Abu Sulayman ash-Shami. ${ }^{58}$ The magazine claimed that Abu Sulayman was a senior figure in the production of IS media, and that he died in January 2017 as a result of a missile strike during a battle. ${ }^{59}$ In a rare incidence, the magazine identified Abu Sulayman by his real name halfway through the article. Even before that, close followers of the American jihadist scene could instantly recognize his identity from the cover photo alone. "Abu Sulayman” was Ahmad Abousamra, a dual Syrian-American citizen wanted by the FBI for providing material support to terrorists. ${ }^{60}$

By the time of his death in 2017, Abousamra had attempted to participate in jihadist organizations across the globe (including Pakistan, Yemen, Iraq, and Syria) for a decade and a half. Abousamra, a computer scientist by training, spoke Arabic and English fluently, was a skilled propagandist with a deep understanding of jihadist ideology. These traits made him an invaluable asset, especially because he also had a knack for eluding U.S. law enforcement. He avoided arrest on multiple occasions and transitioned between two passports and dozens of aliases. In some ways, Abousamra helps elucidate the threat posed by individuals who can seamlessly transition between various jihadist battlefields. As the nature of the Syrian and Iraqi conflicts change, the travelers who will be vital to establishing jihadist campaigns elsewhere may fit profiles like Abousamra's.

\section{Motivations}

Abousamra was born in 1981 in France. ${ }^{61}$ His father, Dr. Abdulbadi Abousamra, moved the family to the Boston, Massachusetts, metropolitan area after accepting a position as an endocrinologist at Massachusetts General Hospital. ${ }^{62}$ Dr. Abousamra is also a prominent Muslim Brotherhood-linked activist and community organizer. He helped found the Islamic Academy of New England and the al-Noor Academy, a private Islamic middle and high school in Mansfield, south of Boston. He was also the president of the Islamic Center of New England's Sharon, Massachusetts, branch, and the vice president of the Muslim American Society of Boston. ${ }^{63}$

Ahmad, nevertheless, attended the Xaverian Brothers Catholic High School while growing up in Boston. ${ }^{64}$ He was on the honor roll, but transferred to Stoughton High School during his senior year, reportedly because Xaverian Brothers did not permit male students to grow beards. ${ }^{65}$ After graduating in 1999, he attended Northeastern University, and eventually transferred to the University of Massachusetts-Boston, where he graduated in 2006 with a degree in computer science. ${ }^{66}$

30 | THE GEORGE WASHINGTON UNIVERSITY PROGRAM ON EXTREMISM 
Around the time of the September 11, 2001, attacks, Ahmad Abousamra reportedly began outwardly expressing his interest in participating in jihadist movements to his circle of friends, including allegedly praising the 9/11 attacks. ${ }^{67}$ One member of this circle was Tarek Mehanna, an Egyptian-American student from Sudbury, Massachusetts, another upper-middle-class suburb in the Boston area. Abousamra and Mehanna were family friends. They also developed a shared interest in Salafijihadism and were highly active on jihadist web forums. In the early 2000s, they began researching ways to travel to Pakistan to attend al-Qaeda training camps using the internet. ${ }^{68}$ Abousamra also contacted Hassan Masood, a Pakistani national with knowledge of the areas in Pakistan with training camps. Masood was the son of the former imam of the mosque in Sharon that Abousamra attended. ${ }^{69}$ The elder Masood was eventually deported to Pakistan for immigration violations. ${ }^{70}$ His brother (and Hassan Masood's uncle), Hafiz Muhammad Saeed, was the founder of Lashkhar-e-Taiba (LeT), a Pakistani affiliate of al-Qaeda. ${ }^{71}$

Abousamra traveled to Pakistan in 2002, with the intent of receiving military training at a LeT training camp. He was given money by an unnamed co-conspirator to donate to the mujahideen. ${ }^{72}$ Upon arrival in Pakistan, he attempted to enter the LeT training camps, but according to Masood, he was "blown off." Abousamra was turned away from the camps because he had no fighting experience, and he was an Arab, and not a Pakistani. ${ }^{73}$ Abousamra eventually met a facilitator named Abdulmajid after talking about a religious slogan with him on a bus; Abousamra believed he could help him gain entry to a training camp. Instead, Abdulmajid instructed Abousamra to return to the U.S. and "do whatever [he could]" to help the cause of jihad. ${ }^{74}$ Upon his return, Abousamra, Mehanna, and a recent convert to Islam named Daniel Maldonado continued to research ways to support jihadist groups overseas and commit attacks at home. ${ }^{75}$

After the Pakistan plan failed, Abousamra and his friends discussed next steps. They planned an attack on a mall in the Boston area, in the hopes of mimicking the terror caused by the 2002 Beltway sniper shootings. ${ }^{76}$ The group discussed other possibilities, including assassinating members of the Bush administration and committing an attack on a local U.S. Air Force base. However, they could not find a source for the automatic weapons that they needed..$^{77}$

Moving forward, the group re-considered jihadist travel. Iraq was initially appealing: the U.S. military engagement there had just started, and al-Qaeda in Iraq (later, the Islamic State in Iraq, the predecessor group to IS) were growing in influence due to high-profile operations. However, Abousamra and his co-conspirators could not determine a way to reach Iraq from neighboring countries. Instead, Abousamra traveled to Sacramento, California, in October 2003 to receive guidance from Jason Pippin, an American-born convert from Georgia who had trained with LeT and also studied in a Yemeni madrassa in the 1990s. ${ }^{78}$ Abousamra met Pippin on an online Salafi-jihadist web forum. Pippin discussed his experience in Yemen and gave Abousamra and Mehanna advice about how to travel and who to contact. ${ }^{79}$ Abousamra gave Pippin $\$ 5,000$ for a plane ticket, hoping that he would join them. However, Pippin remained in California.

\section{Journey}

In February 2004, Abousamra, Mehanna, and an unnamed co-conspirator embarked on their journey to Yemen through the United Arab Emirates. ${ }^{80}$ All three only saw Yemen as a transition point. ${ }^{81}$ Per Pippin's advice, they were to stay in Yemen for a few weeks to participate in a training camp, before eventually transferring to the battlefield in Iraq to fight with AQI. ${ }^{82}$

On arrival in the United Arab Emirates from the U.S., the unnamed co-conspirator dropped out after he received a call that his father was sick. He gave Mehanna and Abousamra the money he had saved for the trip-a few thousand dollars-and promptly returned to the U.S. ${ }^{83}$ Mehanna and Abousamra entered Yemen on February 4, 2004. ${ }^{84}$ Again, their attempt to find a suitable training camp was thwarted. Abousamra went onwards to Iraq to fight for AQI, arriving in the country on February $13 .^{85}$ Mehanna, on the other hand, returned the U.S. and acted 
as a conduit between the al-Qaeda media offices and Western jihadists by translating propaganda material. ${ }^{86}$

Abousamra's first Iraq expedition did not last long, either. After two weeks in-country, he traveled through Jordan and his father's home country of Syria, eventually returning to the Boston area in August $2004 .{ }^{87} \mathrm{He}$ then regrouped with Mehanna, who described their new role to another unnamed individual as "the media wing" of AQI, assisting in the translation of several videos produced by the group from Arabic into English. ${ }^{88}$ As late as April 2006, Mehanna and Abousamra were in contact, hatching a plan to reach out to the leader of LeT in the hopes of traveling to Pakistan again. ${ }^{89}$ Another member of Abousamra's group of friends, Daniel Maldonado, went to Somalia in 2006 with his family and another American, Omar Hammami (also known as Abu Mansur al-Amriki), whom he met online. ${ }^{90}$ Maldonado attended a training camp run by al-Shabaab; after catching malaria and escaping Somalia into Kenya, he was apprehended by Kenyan forces in 2007, extradited to the U.S., and sentenced to 10 years in federal prison. ${ }^{91}$

Maldonado called Mehanna while he was in Somalia prior to his arrest. At this point, federal agents were monitoring Mehanna and Abousamra, and knew that Maldonado had reached out to Mehanna about his purpose of travel to Somalia. ${ }^{92}$ In December 2006, FBI agents interviewed Abousamra first and Mehanna second, four days apart. Authorities inquired about their respective trips to Yemen and Iraq and Mehanna was also asked about Maldonado's call. ${ }^{93}$ According to court documents, Abousamra lied about the "purpose and intended destination [s]" of his two trips to Yemen and Iraq; Mehanna lied not only about these activities, but also provided false information about the location of Daniel Maldonado. ${ }^{94}$
Abousamra saw the writing on the wall and fled the country in December 2006. At this point, he had already graduated from UMass-Boston. ${ }^{95}$ Tarek Mehanna, absent a second passport and held down by studies at the Massachusetts College of Pharmacy, stayed behind. Mehanna and Abousamra (in absentia) were indicted in 2009 on a variety of charges, including providing material support to designated FTOs, conspiring to kill U.S. nationals in a foreign country, and making false statements to the FBI. ${ }^{96}$ A jury convicted Mehanna and he was subsequently sentenced to 17 and a half years in federal prison in $2012 .^{97}$

Abousamra vanished after his December 2006 departure. The FBI did not place Abousamra on a watchlist before his departure, reportedly for "operational reasons." ${ }^{\text {" }} \mathrm{He}$ repatriated to Syria, and settled in the Aleppo area with his wife and at least one child. By the time a court issued his arrest warrant in 2009, Abousamra was well outside the reach of American law enforcement. In December 2013, the FBI listed Ahmad Abousamra as a "Most Wanted Terrorist," and offered a reward of $\$ 50,000$ for information leading to his arrest. ${ }^{99}$ However, there was no updated information regarding his activities since the departure to Syria. It was unclear whether he was involved in jihadist activity in Syria or the region in between when he left the U.S. in 2006, and the beginning of the Syrian conflict in 2011.

\section{Abousamra in Syria}

The first verification that Abousamra had joined a faction of the Syrian conflict was in 2014. A senior U.S. law enforcement official revealed that Abousamra had joined IS, claiming that the group had assigned him to assist in their efforts to spread their Englishlanguage propaganda on social media. ${ }^{100}$ At this time, scholars, analysts, and governments were still attempting to uncover the leadership behind the IS media 
distribution division. Two features that seemed to distinguish the media operations of IS from previous jihadist organizations' material was their professional-quality productions and their ability to disseminate this content through social media.

Abousamra, in his years of attempting and failing to find a long-term role in several jihadist organizations, found a match in IS. After the start of the Syrian conflict, he lived in one of the hotspots of resistance to the Syrian regime on the battlefields of Aleppo. His eulogy in Rumiyah claims that he joined one of the factions in Aleppo, but was wounded in a battle. He eventually came across soldiers affiliated with IS in Iraq, who Abousamra recognized as the successor of al-Qaeda in Iraq, the organization that he fought for and assembled media products for nearly a decade prior. ${ }^{101}$ The soldiers were fighting in the Aleppo region under the name of Jabhat al-Nusra li-Ahl ash-Sham (The Victory Front of the People of Sham). ${ }^{102}$

He first requested that these soldiers take him to Iraq, which was denied. Then, he asked to participate in a suicide bombing, which was also rejected. Eventually, he found a role "preaching aqidah [the creed]" to the soldiers. ${ }^{103}$ During this period, the split between JN and IS occurred, and Abousamra joined the ranks of the faction's soldiers who pledged allegiance to $\mathrm{Abu}$ Bakr al-Baghdadi. A wounded Abousamra was set to participate in a suicide bombing mission early in his career with IS, but by chance he came into contact with one of the senior-most members of the media division of IS, Wa'il al-Fayad (Abu Muhammad al-Furqan). ${ }^{104}$ Abousamra's eulogy claims that al-Fayad instantly recognized Abousamra's talent, brought him on board to the media team, and sent another fighter in his place for a suicide mission. ${ }^{105}$

Abousamra's first job in the IS media department was ghostwriting treatises and opinions for the director, alFayad. Abousamra used the pen name "Abu Maysarah ash-Shami" to denote the articles he wrote on behalf of al-Furqan, most of which are available in Arabic and take an especially harsh stance on Salafi-jihadist organizations that had not declared allegiance to Abu Bakr
al-Baghdadi. ${ }^{106}$ The most famous of Abousamra's essays written under the Abu Maysarah nom du plume coined the phrase "Jews of Jihad." This has since become the common pejorative used by IS supporters to refer to followers of al-Qaeda's current leadership, particularly Ayman al-Zawahiri. ${ }^{107}$ In the essay, Abousamra claimed that al-Qaeda and its leaders were the contemporary equivalent to the Jews during the time of the original Caliphate, who converted to Islam not due to their belief in the religion, but because they merely feared their declining political position in the Arabian Peninsula if they did not. ${ }^{108}$

Eventually, al-Fayad rewarded Abousamra for his efforts. In July 2014, IS' al-Hayat Media Center, directed by al-Fayad, published the first issue of the monthly magazine Dabiq. ${ }^{109}$ The issues of Dabiq, which ran for a two-year period until July 2016, were translated into several languages. Abousamra, now under his own kunya of Abu Sulayman ash-Shami, was responsible for directing translation efforts (especially for the English version), and was the magazine's chief editor and a frequent contributor. ${ }^{110}$

Al Arabiya, citing a source from the Iraqi Ministry of Interior, claimed in May 2015 that the Iraqi military killed two Americans who had been senior members of IS' media team, as the result of a strike in the west of Anbar province near Fallujah. The men were named as Abu Osama al-Amriki, a documentary filmmaker, and another filmmaking expert, Abu Mohammad al-Suri, also known as "Abu Samra."111 While proof of death was unconfirmed, the Iraqi military made a concerning claim that Abousamra was involved in the filming of the infamous videos depicting the beheadings of James Foley, Stephen Sotloff, David Haines, Alan Henning, and Peter Kassig in 2014. ${ }^{112}$ These claims were not verified, although evidence that Abousamra was directly involved in English-language media production for IS around this time lends them some credence.

According to IS sources, Abousamra was working with Wa'il al-Fayad on a new magazine product, Rumiyah, in the fall of 2016; this contradicts the claim that Abousamra was killed in 2015. ${ }^{113}$ The first version of 
Rumiyah, released on September 5, 2016, hailed the death of IS' official spokesperson, Abu Muhammad al-Adnani, who reportedly died in late August. ${ }^{114}$ According to some sources, al-Fayad, Abousamra's mentor, was slated to assume al-Adnani's role. ${ }^{115}$ However, al-Fayad was killed two days after the release of the first issue. ${ }^{116}$

Following al-Fayad's death, Abousamra could have taken his job as director of the IS media division. Abousamra's eulogy, however, reports that the death of his mentor "greatly saddened" him, and that in the days following his passing, Abousamra requested to return to the battlefield rather than staying to manage the media office. He was transferred to ribat (forward position) in al-Thawrah, Syria, where he was reportedly killed in January 2017. ${ }^{117}$ Alongside his eulogy appearing as the feature article of the eighth issue of Rumiyah is an original poem scripted by Abu Sulayman ash-Shami called "The Bliss of a Martyr."

The U.S. government has not verified Abousamra's death. The FBI reward offered for information leading to his capture or arrest remains active-in the cases of other known jihadists who have been confirmed dead, the Bureau traditionally retracts the reward offer. A senior law enforcement also claimed that IS issued false death claims in the past to "get the heat off" their leaders if they were subject to surveillance or a targeted airstrike. ${ }^{119}$

Outside the death claim, there are, however, some interesting commonalities and discrepancies between the account in Rumiyah and U.S. law enforcement's timeline. The article places Abousamra in Aleppo around the same time that the FBI released updated information that he was living there in 2013. It states that Abousamra was active on the Aleppo front of the jihadist resistance, and adds that his counterparts often referred to him as "Abu Sulayman al-Halabi" (Halab referring to the Arabic name for Aleppo), rather than the more generic Abu Sulayman ash-Shami (the Syrian) or al-Amriki (the American). ${ }^{120}$ The eulogy also gives an account of Abousamra's previous travel to join jihadist groups, claiming that he:

... completed his studies in Computer Science at the University of Massachusetts in Boston, graduating as an engineer and programmer, before resolving

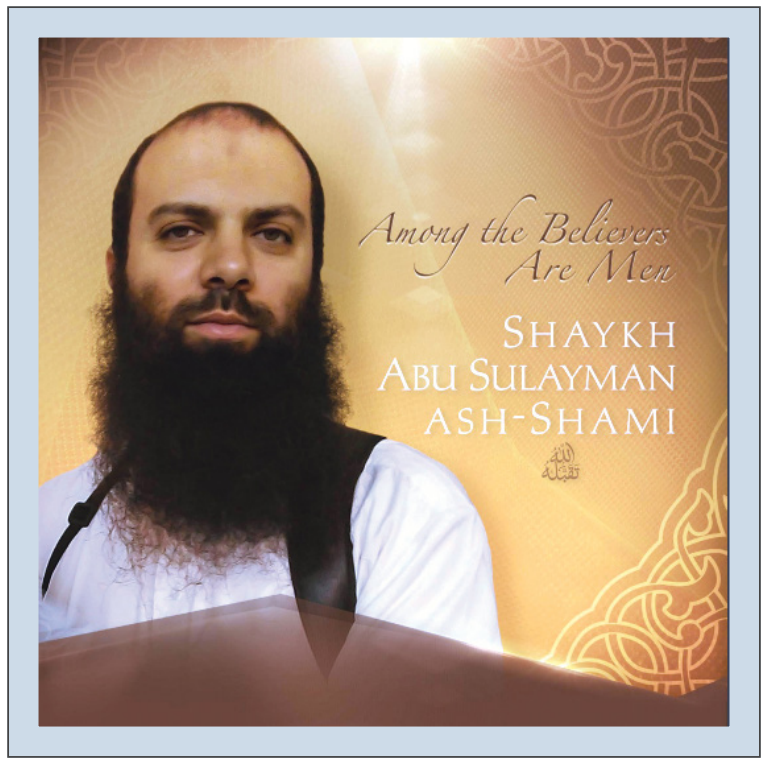

Image from Abousamra's eulogy in Rumiyah, issue 8. April 2017.

to go forth in the cause of Allah with some of his friends. So they left as muhajirin [travelers] to Allah, not coordinating their journey with anyone. They roamed between Yemen, Pakistan, and Iraq, hoping to meet someone who would bring them to the mujahideen. But once they became weary of finding the way, and as they feared inciting the suspicions of intelligence agencies, they returned to America, asking Allah to guide them towards their goal. ${ }^{121}$

Two elements of the eulogy differ from the details on Abousamra included in court documents in the Mehanna trial. The eulogy states that he was close to carrying out a jihadist attack with "two of his companions" that would involve "seizure of some weapons from the Crusaders, which they would then use for an attack behind enemy lines that they hoped would cause the killing of a large number of mushrikin [polytheists]."122 This account varies from the FBI account regarding the sequencing of the attack plot. According to court documents, Abousamra and Mehanna discussed committing attacks in the U.S. before their trip to Yemen in 2004; according to Rumiyah, they continued discussing this plot and were in the final stages of preparation when FBI agents interviewed Mehanna and Abousamra in 2006, which prompted Abousamra to leave the country. Whether 
this claim is jihadist bluster, a "journalistic" mistake, or direct evidence that the two continued their interest in a domestic attack after returning from Yemen is hard to parse.

The eulogy also documents another plot by Abousamra to kill a U.S. citizen overseas, claiming that he "took part in planning to kill the American apostate Hamza Yusuf during his last trip to Turkey." 123 Yusuf, a prominent American Islamic scholar and co-founder of Zaytuna College, did visit Turkey in the aftermath of the July 2016 military coup attempt. ${ }^{124}$ However, Rumiyah's account does not provide any more details about this plot or Abousamra's involvement.

Ahmad Abousamra is another instructive example of a "pioneer." He arrived in Syria at least five years before any other Western traveler had done so. Like Pazara, he managed to find himself in the right place at the right time in Syria's jihadist networks, directing himself towards the political allegiances and critical relationships that allowed him to rise in the ranks of his group's leadership. His skills, including language proficiency, religious knowledge, and technical know-how, set him apart from other recruits. Unlike Pazara, Abousamra reportedly did not directly reach out to individual Americans in his networks back in the U.S. (according to available public knowledge). Nevertheless, his role as a propagandist and media distributor allowed him to edge himself into the media products, treatises, and scholarship that attracted thousands of other travelers to Syria and Iraq to fight for IS.

\section{Pioneers: Enduring Relevance for Jihadist Groups}

From a security or law enforcement perspective, jihadist pioneers pose vexing challenges. Not only do they have deep influence in homegrown networks, but if not killed or apprehended while in Syria and Iraq, this category of traveler is the most likely to drive recruitment efforts to new battlefields. Besides, few Americans possess the capabilities or influence necessary to rise in the ranks of jihadist organizations. Many do not have the required combat experience, language abilities, technical skills, or connections necessary to amount to much more than foot soldiers in insurgent militant organizations. Pioneers stand out in this regard; they often possess one or more of these qualities and build on them after their arrival in Syria and Iraq.

However, date of arrival in Syria can sometimes be misleading: some early arrivals were killed quickly, reneged on their beliefs, or struggled to adapt to their new circumstances. The mere feat of a pioneer's survival and longevity in a combat or insurgency environment is a testament either to outright skill or tactical and strategic adaptation. Both Pazara and Abousamra lasted through their first combat experiences in Bosnia, Pakistan, Yemen, and Iraq, respectively. Abousamra was never arrested, despite transiting back and forth between the U.S. and the three different countries in which he attempted to receive military training from jihadist organizations. Pazara hid his wartime records, allowing him to avoid potential war crimes prosecution or deportation in the U.S.

Moreover, pioneers are specialists in critical skills needed by jihadist groups. The majority of American travelers to Syria had little to no combat experience prior to their travel. While Abousamra did not have extensive combat experience, he was able to distinguish himself in Syria through his understanding of Salafi-jihadist ideology, abilities as a propagandist, and computer skills. This combination made him incredibly important to IS. At the time he joined, IS was in the process of revolutionizing its branding through stark points of departure from the current debates in Salafi-jihadism, propaganda that could appeal to Western (and especially Englishspeaking) audiences, and a comprehensive use of digital communications technology. Assisting in these efforts may not have constituted an automatic entry ticket into the leadership ranks of LeT, AQAP, or AQI, but they did for IS during that time.

Lastly, pioneers make the right connections. Sometimes, this happens as a result of random occurrences. Abu Muhammad al-Furqan stumbled across Ahmad Abousamra, a zealous but wounded Syrian-American with experience in the media business and computer 
skills, just as he was about to undertake a suicide mission. Abdullah Ramo Pazara happened to arrive in Syria just as the split between AQ and IS was being finalized, propelling his countrymen into leadership roles.

These three characteristics-adaptability, technical skills, and connections-are also why the category of pioneer travelers must be examined as part of the larger threat that jihadist travelers pose to the U.S. and the West. The current debate focuses heavily on the danger of returning fighters and whether the territorial demise of organizations like IS will increase the likelihood of homegrown attacks or broader recruitment networks, jump-started by returnees.

This debate, while useful and necessary, could benefit from an assessment of which kinds of travelers pose the largest threat from a national security perspective. The Pazara and Abousamra stories add some insight in this regard, not only into how returning travelers have influenced recruitment in the U.S., but also the comparative risk of returnees and pioneers.

Both Abousamra and Pazara had contact with veterans of jihadist campaigns at some point during their sagas, with Abousamra talking to at least one returned traveler. Abousamra traveled from Boston to Sacramento, California, to meet Jason Pippin, who had returned from a training camp in Kashmir operated by LeT, via a madrassa run by another "Afghan Arab" whom he met in Yemen. After his return to the U.S., Pippin remained active on several jihadist web forums, which is where he first encountered Abousamra. Pippin advised Abousamra about jihadist training camps in Yemen, testifying at Mehanna's trial that he told Abousamra which airport to travel through, which madrassas to attend, and who to contact. Although Abousamra eventually was unsuccessful in his search for training camps in Yemen, in this case, Pippin, a returned traveler, provided expertise, contacts, and other information about fighting for jihadist groups overseas.

Pippin, a former "pioneer" himself, returned to the U.S. and continued to assist in jihadist recruitment until 2005, when he denounced extremism. He eventually became a government witness in the trial against Mehanna.
Nonetheless, this incident shows that while returning travelers from Syria and Iraq, especially returning "pioneers," may not directly participate in attack plots or travel themselves, they retain the contacts and skills that they attained during their travel. They may attempt to assist the next generation of recruits in reaching those territories, or whichever battlefield overtakes them as the next attractive destination for jihadist travelers.

Pazara's commander Bajro Ikanovic was not a returnee. Instead, he was a veteran of a homegrown cell of al-Qaeda supporters in Sarajevo. The relationship between Pazara and Ikanovic demonstrated the inverse of the argument that former travelers return home and spur homegrown plots: in this instance, Ikanovic, a former homegrown plotter in Bosnia, traveled overseas to Syria and facilitated the travel of other individuals.

Returning pioneers are likely to be few and far between. Those who do come back to the U.S. may not attempt to participate in attacks themselves, but may encourage others to either commit violent acts or travel overseas to join jihadist groups. From previous mobilizations, there are several relevant examples of both. Christopher Paul, a former participant in the Afghan and Bosnian jihad, was contacted when he returned to Ohio by two men who wanted to conduct a bomb attack at a mall. Like Pippin, Paul shared his expertise with the group in a series of meetings, but authorities arrested all three before the plan came to fruition. Daniel Curtis "Saifullah" Boyd, also a returnee from training camps in Afghanistan and Pakistan, set up another camp in North Carolina, where several individuals who eventually traveled or attempted to travel to join jihadist groups underwent military training.

A more pertinent issue related to pioneers, however, concerns who the next generation of pioneers will be when the next major battlefield opens after Syria and Iraq. The travelers who pick up their first major experience with jihad and jihadist movements in Syria and Iraq and then transition to another campaign will be the Ahmad Abousamras and Abdullah Ramo Pazaras of tomorrow. If the history of Americans participating in jihadist organizations is any indication, the next generation 
of pioneers will be crucial to recruiting and inspiring Americans to join alternative battlefields. Whether it will be in the Middle East, North Africa, Southeast Asia, or anywhere else remains to be seen. Like their counterparts who carried their experiences from previous military engagements to Syria and Iraq, these recruits will represent the upper echelon of American jihadists.

The most concerning takeaway from the current generation of pioneers is that it is difficult to determine which of the contemporary travelers may become pioneers in subsequent mobilizations. While Pazara had combat experience, he garnered it in a completely different ideological context outside the confines of the Salafi-jihadist movement. Abousamra, for various reasons, was unable to join jihadist groups during his first attempts in Pakistan, Yemen, and Iraq. Even those who have attempted but failed to travel to Syria may be successful in traveling to other battlefields and rising the ranks there. Nevertheless, the pioneer category is the foremost example of the linkages and networks between jihadist organizations in different geographic and temporal contexts. It is therefore prudent for analysts, scholars, and law enforcement to place extra attention on which individuals become "pioneers," and how they manage to do so. 



\section{Category 2: Networked Travelers}

$\mathrm{T}$ The majority of known American travelers did not make the journey alone. Instead, they formed groups of individuals who worked with others to plan and execute their eventual departure. For many American travelers, their best chance to reach jihadist-held territory was to build strength in numbers. Due to the role of interpersonal relationships in facilitating their travel, this report refers to these travelers as "networked travelers."

In many cases, networks are essential. What is less apparent, however, is how they matter, and which types of networks are likely to facilitate travel. To this end, this section presents several stories of various types of networked travelers, with a focus on their motivations and how they used social connections to travel to Syria and Iraq. Given that many of these individuals were part of a more extensive web of supporters who may not have been charged publicly with criminal activities, details of their radicalization may not be available. Wherever possible, the authors attempted to augment information through interviews with family members, friends, and lawyers prosecuting or representing those in that circle.

In this study's review of networked travelers, three types of networks frequently appear: community-based clusters, friend groups, and families. In the American context, the last two types of networks are more frequent. They comprise specific families or tight-knit friend groups that travel alongside one another or support the jihadist cause in a variety of ways (planning attacks, financing, etc.). Less common are clusters, which are made up of multiple family and friend groups within a specific community, that all participate in jihadist activity. This section highlights cases within each sub-category of networked travelers, including an extensive description of one of the only known clusters of the American jihadist scene.

\section{Clusters}

The Minnesota Cluster

From 2013 until the end of 2017, at least seven residents of the Minnesota Twin Cities area traveled to Syria and Iraq to fight. Concurrently, at least ten residents attempted to travel but were unsuccessful. This rate of jihadist mobilization makes the state of Minnesota, and the Twin Cities more specifically, among the highest producers of jihadist travelers to Syria and Iraq in the U.S.

The Minnesotan contingent in Syria and Iraq is welldocumented. The court cases against the ten unsuccessful travelers revealed a wealth of information regarding other Twin Cities residents who successfully traveled. A U.S. House of Representatives Homeland Security Committee report found that more than one-quarter of successful and unsuccessful U.S. travelers came from Minnesota. ${ }^{1}$ During a 2015 press conference, then-U.S. Attorney Andrew Luger, responsible for prosecuting the majority of Minnesota's IS-related cases, was more direct in his assessment: "We have a terror recruiting problem in Minnesota."2

However, the Syria and Iraq-related mobilizations from Minnesota were not without precedent. Nor are they the largest mobilization of Minnesotans. From 2007 to 2013, at least 23 young men from the Twin Cities participated in a different conflict-the civil war in Somalia. ${ }^{3}$ After Ethiopian forces invaded Somalia in 2006, many young men from the Twin Cities, most of whom were Somali immigrants to the U.S. or second-generation SomaliAmericans, traveled to Somalia to fight. ${ }^{4}$ All of them joined the jihadist group al-Shabaab. ${ }^{5}$

When the Syrian conflict flared up in the early 2010s, another wave of young men from Minnesota traveled to Syria and Iraq. The travelers from Minnesota in both waves were mostly Somali-American, with some exceptions. More importantly, however, there are networked 
links between the mobilizations. The majority of the seven travelers to Syria and Iraq had, at the time of their travel, connections to at least one other traveler or attempted traveler. Some had links to the first wave of Minnesotan travelers to Somalia.

These connections were formed by a conglomerate of the first two types of social networks-friendship and kinship. When the first Minnesotans arrived in Syria, they attempted to recruit their friends and family from back home in the Twin Cities to join them. Then-U.S. Attorney Luger described this recruiting strategy as a "peer-to-peer, brother-to-brother" approach, noting that "the person radicalizing your son, your brother, your friend, may not be a stranger. It may be their best friend right here in town."

To illustrate how deep and networked many of these connections were, critical examples include the first three individuals with roots in Minnesota to travel to Syria and Iraq: Abdifatah Ahmed (aka Abdirahmaan Muhumed), Hanad Abdullahi Mohallim, and Douglas McCain. By many accounts, Ahmed was the first Twin Cities resident to arrive in Syria and Iraq. ${ }^{7}$ Ahmed left Minnesota for London in 2013. The individuals who communicated with him while he was in London claim his decision to travel to Syria in the winter of 2013 was seemingly instantaneous. One day, he was broke, despondent, and constantly chewing khaat (a plant-based stimulant popular in the Horn of Africa), the next day there were rumors in Minneapolis that he had joined a jihadist group in Syria. ${ }^{8}$

In January 2014, it was clear that Ahmed joined a jihadist group in Syria. He posted two photos on his Facebook page of him standing under a black flag, with a Quran in one hand and an AK-47 in the other. These photos were posted with the caption, "I give up this worldly life for allah and to save the ummah if that makes terrorist I am happy with it." He told a friend from Minnesota, who later became a confidential human source for the FBI, that "Islam is not just praying $\mathrm{u}$ know ... Someone who get kill for the sakeof Allah can ask allah to for give up to 70 of his family." 10
One month later, he contacted another old friend from Minnesota via Facebook. Douglas McCain, a graduate of Robbinsdale Cooper High School in New Hope, Minnesota, converted to Islam in $2004 .{ }^{11}$ McCain went to the same high school as Troy Kastigar, another Muslim convert from Minnesota who was killed fighting for al-Shabaab in Somalia in 2009. The two were also roommates for a brief period. ${ }^{12}$ McCain later moved to San Diego, California, where he was residing at the time of his departure from the U.S. While not Somali-American, McCain had deep ties to the Somali community, and was employed in a Somali restaurant in San Diego at the time of his departure. ${ }^{13}$

In March 2014, McCain contacted Ahmed via Facebook private message and gave him his contact information.


Pictures from Abdifatah Ahmed's Facebook account depicting him in Syria, 2014. Pictures obtained from Minnesota Public Radio. 

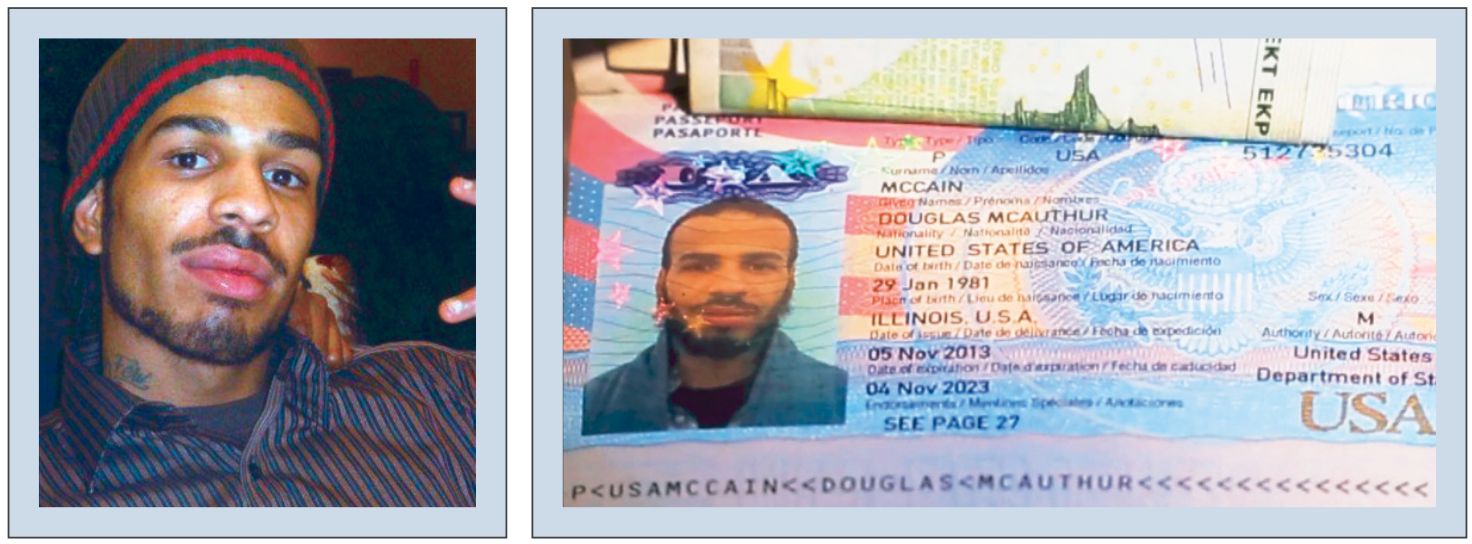

Left: Douglas McCain (Facebook). Right: McCain's U.S. passport, recovered by militants in Syria after his death.

He also told Ahmed: "In sha Allah i need to hala at $\mathrm{u}$ I am flying out to Turkey." ${ }^{14}$ Ahmed scolded McCain, telling him not to discuss jihadist travel on Facebook and instructed him to turn off the location services on his phone. ${ }^{15}$ On March 9, McCain traveled from San Diego to Istanbul. On the same day, Minnesota resident Hanad Mohallim departed from Minneapolis to Istanbul. The FBI later discovered that McCain and Mohallim's tickets were both fraudulently paid for with the same credit card, which belonged to McCain's brother's girlfriend. ${ }^{16}$

Hanad Mohallim was 18 years old at the time of his departure. He had recently switched between several Minneapolis-area high schools due to academic difficulties. ${ }^{17}$ On the day of his departure, he told his family that he was going out for a job interview. ${ }^{18}$ His mother, who noticed a significant change in Mohallim's religious beliefs prior to travel, realized that Mohallim was attempting to travel. Daringly, she went to Turkey to try to find Mohallim and bring him back to Minnesota. ${ }^{19}$ In Turkey, she spoke with Mohallim several times, but to no avail. She later recounted to federal investigators that Hanad was working as a border guard for a jihadist group and had no intentions of returning to the U.S. ${ }^{20}$

When federal investigators interviewed Mohallim's mother, they uncovered critical information regarding her son's connections. First, Mohallim's mother immediately recognized a picture of McCain, who she referred to as "Duale" and "Doug." 21 McCain used "Duale" as his name on Facebook and in other social media accounts. ${ }^{22}$ She also commented that Mohallim met McCain through her nephews, who lived in Edmonton, Canada. According to Mohallim's mother, Hanad Mohallim's travel to visit these cousins in 2013 sparked his interest in jihad. ${ }^{23}$

Across the border, Canadian authorities also identified three of Mohallim's cousins in Edmonton as jihadist travelers. Brothers Hamse and Hersi Karie, and their cousin Mahad Hirsi, all left Edmonton in October 2013 and were believed to be in Syria. ${ }^{24}$ The Karie brothers are U.S. permanent residents and previously lived in San Diego and Minnesota. Several members of the Karie family knew McCain personally. ${ }^{25}$

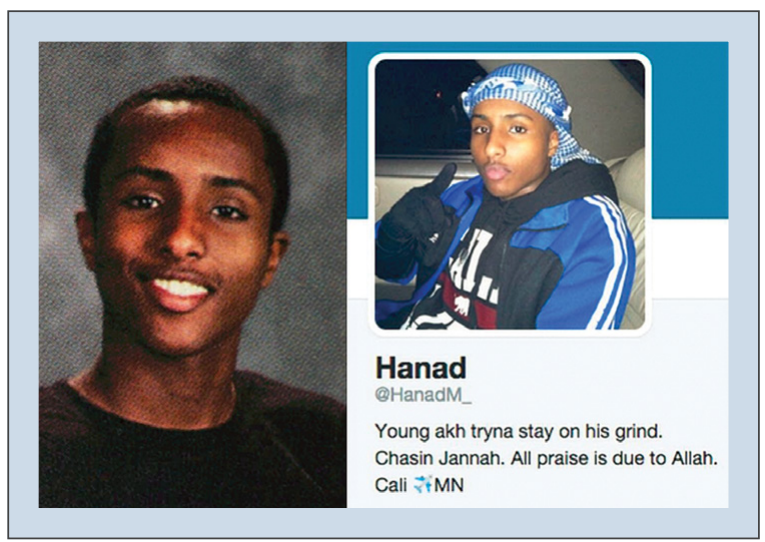

Hanad Mohallim's high school yearbook picture (L) and Twitter account (R). Pictures obtained from Minnesota Public Radio. 
On March 10, 2014, one day after McCain embarked on his travel, a third Karie brother arrived in San Diego and contacted McCain. McCain replied that he "wasn't in [San] Diego" and that he "went to go hala at yo brothers." ${ }^{26}$ This was a reference to Hamse and Hersi Karie, who were already in Syria. One month later, McCain messaged the third Karie brother from Turkey, informing him that he had arrived. The brother responded, "where is the little [expletive]," referencing Hanad Mohallim, his cousin. ${ }^{27}$ McCain told the brother that he and Hanad Mohallim had connected with Hamse Karie, Hersi Karie, and Mahad Hirsi, and were on route to Syria. ${ }^{28}$

Upon arrival in Syria, all five travelers-Abdifatah Ahmed, Douglas McCain, Hanad Mohallim, Hamse Karie, and Hersi Karie-remained in contact with friends in Minnesota and San Diego. They were also active on social media. The pictures, videos, and statuses posted by Ahmed, McCain, and Mohallim on their social media accounts had particular credence in the Twin Cities, where young men in their friend and family circles gained a new-found inspiration for traveling to Syria and Iraq to join IS.

By the end of 2014, all five travelers were reported dead within weeks of one another. Douglas McCain became the first American to be reported by the U.S. government as killed in Syria and Iraq. ${ }^{29} \mathrm{He}$ died in a battle between IS and the FSA in late August 2014. Abdifatah Ahmed died in Syria during the same period. ${ }^{30}$ In late 2014, Hanad Mohallim, Hamse and Hersi Karie, and Mahad Hirsi were killed during the battle of Kobani. ${ }^{31}$

By that time, however, this first group of travelers had laid the groundwork for others to attempt to travel to Syria and Iraq. Prior to his death, Hanad Mohallim was in contact with his best friend from Minnesota, Abdullahi Yusuf. Yusuf reached out to Mohallim shortly before the latter departed from Minneapolis and exchanged several phone calls and text messages during the course of Mohallim's time in Syria. ${ }^{32}$

Yusuf contacted Mohallim when he was in the planning stages of his own travel to Syria to join IS. Defaulting again to the "strength in numbers" approach, Yusuf found a fellow traveler, Abdi Nur, to join him on his journey to Syria. Nur and Yusuf both attended the Dar al-Farooq Youth and Family Center, an Islamic community center in Minnesota. ${ }^{33}$ They met each other through a mutual friend, Guled Omar, who was the "ringleader" for several other Minnesota travelers in their attempts to travel to Syria. ${ }^{34}$

Before their travel, Nur and Yusuf operated in lockstep to prepare themselves for the journey and ensure that they would not be detected. They went on a shopping trip to Macy's to buy gear and clothing. They purchased plane tickets to Istanbul, scheduled for back-to-back days in May 2014. ${ }^{35}$ Then, both men made fateful trips to attain expedited U.S. passports at a local issuing office in Minneapolis.

Abdi Nur went to the Minneapolis Passport Agency first, on April 24, 2014. He listed his intended travel destination as Australia, and the application interview proceeded normally. Eventually, the agent approved his passport application. ${ }^{36}$ Four days later, Abdullahi Yusuf went to the passport agency. He listed his destination as Turkey. By all measures, Yusuf botched the interview. He gave conflicting accounts about his purpose of travel to Turkey, could not remember specific details about his travel plans, and was visibly nervous, lowering his voice and avoiding eye contact with the agent. ${ }^{37}$ The interview raised enough suspicion for the passport agent to inform their supervisor, who then tipped off the FBI. ${ }^{38}$

The passport agency also approved Yusuf's application, but the FBI closely monitored his activity. Yusuf raised additional concern when he used his new passport to open a checking account, with which he purchased his ticket to Istanbul. ${ }^{39}$ On the day of Yusuf's planned departure, Nur also drove Yusuf to the train station, where he would take a train to Minneapolis-St. Paul International Airport. ${ }^{40}$ On May 28, 2014, federal agents apprehended Yusuf as he attempted to board his flight. ${ }^{41}$

Nur, whose efforts to attain a passport and travel ticket did not elicit the same level of suspicion, successfully boarded his flight from the same airport the next day. A day after he traveled, a member of Nur's family alerted federal agents. They disclosed chat records with Abdi 
Nur on the messaging application Kik. In these chats, Nur claimed that he had "gone to the brothers" and that "everybody dies but I want the best death ... take care of hooyo [mother] for me inshallah." ${ }^{42}$

After arriving in Syria, Nur reached out to other Minnesotan travelers for advice and guidance. He was a long-time Facebook friend of Mohamed Abdullahi Hassan, more commonly known as "Mujahid Miski." 43 Hassan left Minnesota for Somalia during the peak of the first wave of recruitment in 2009, and joined alShabaab at the age of 18 . He established an extensive social media presence under the "Mujahid Miski" label, and used his accounts to promote al-Shabaab, and later IS. ${ }^{44} \mathrm{He}$ was linked to several jihadists in the U.S., including Elton Simpson, the perpetrator of the 2015 attack in Garland, Texas, and Nicholas Rovinski, who planned several assassinations. ${ }^{45}$

In an early August 2014 conversation, Hassan asked Nur how many "brothers from mpls [Minneapolis]" traveled to the battlefields in Syria. ${ }^{46}$ Nur replied that besides him, three had successfully entered Syria-potentially referring to Abdifatah Ahmed, Douglas McCain, and Hanad Mohallim-and "others" were planning to travel. ${ }^{47}$ Hassan gave Nur some sage advice, from one Minnesotan traveler to another. After asking Nur if he knew "Duale" (Douglas McCain), Hassan informed him:

try to all connect and make one of you guys mas'uul [a Somali term referring to a guardian, or someone that is responsible for others' affairs] ... being connected in jihad make you stronger and you can all help each other by fulfilling the duties that allah swt put over you ... like us in Somalia the brothers from mpls are well-connected so try to do the same... It is something we have learned after 6 years in Jihad. ${ }^{48}$

It is unclear whether Nur knew Ahmed, McCain, and Mohallim personally prior to his travel. However, heeding Hassan's advice, Nur continued to encourage and assist other travelers from Minnesota.

In addition to Abdullahi Yusuf, nine other men from Minnesota who knew Abdi Nur personally attempted to travel to join IS. Two of them (Yusuf Jama and Mohamed
Roble), successfully reached Syria, while the remainder (Zacharia Abdurahman, Hamza Ahmed, Abdirahman Daud, Adnan Farah, Mohamed Farah, Hanad Musse, and Guled Omar) were unsuccessful. AnotherTwin Cities resident, Abdirizak Warsame, provided financial and logistical support to the others. Before Nur's departure, this group, in varying combinations, held meetings with each other regarding travel to Syria at the Dar al-Farooq center and several Somali restaurants in the Twin Cities area.

One of the successful travelers, Mohamed Roble, was Nur's nephew. ${ }^{49}$ He applied for a passport in late August 2014, weeks after Nur's conversation with Miski, and days after Douglas McCain's death. Roble used a settlement check from a previous personal injury suit to finance his travel, once the funds became available to him on his 18th birthday. ${ }^{50}$ Learning from Abdullahi Yusuf's mistakes, Roble's passport application listed his destination as China rather than Turkey. ${ }^{51} \mathrm{He}$ did not travel from Minneapolis to China alone-he left the Twin Cities with his mother (Nur's sister). ${ }^{52}$ Once he arrived in China, he planned an excursion to Istanbul in December 2014. He absconded to Syria during this trip to Istanbul. ${ }^{53}$ His friends in Minnesota identified him in early 2015 photographs depicting him fighting for IS in Syria. ${ }^{54}$

Other rumors about Roble's and Nur's activities in Syria also reached a network of their friends in Minnesota. In March 2015, Guled Omar told a confidential human source in Minnesota that Roble had brought a significant portion of his settlement money with him to Syria. Using these funds, he reportedly bought Nur and another Somali fighter named Khattab al-Somali new cars and paid for two of Khattab's marriages. ${ }^{55}$

One leading source of information for those who remained in Minnesota was Abdi Nur's social media presence. Using the Twitter handle "DustyFeet," referring to a quote from the Prophet Muhammad, he posted frontline pictures and updates from the battlefields of Syria, depicting himself as an average kid from Minnesota who found his destiny in jihad. ${ }^{56} \mathrm{He}$ also interacted with several of his friends in Minnesota. Some 


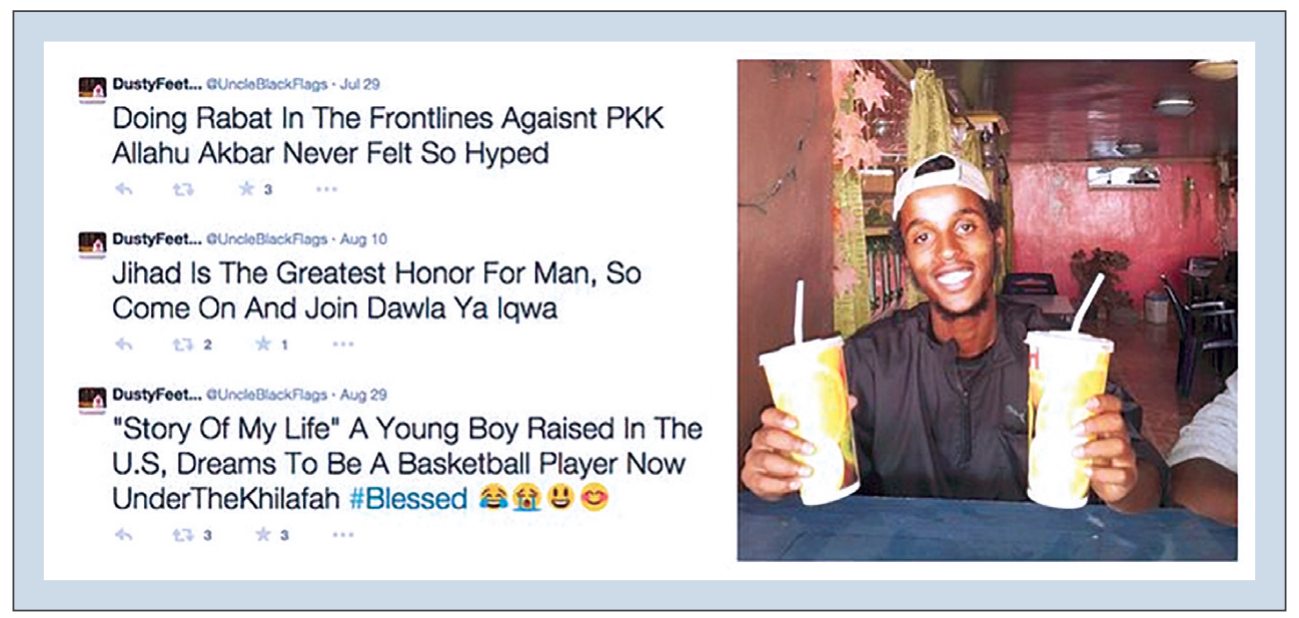

Tweets from Abdi Nur's "DustyFeet" account (L) and his Facebook picture (R). Pictures obtained from the New York Times.

of them were concerned about his disappearance, and others sought to join him. ${ }^{57}$

Directly after Nur traveled to Syria in late May, three other Minneapolitans started planning their course of action. Yusuf Jama, Guled Omar, and an individual who later became a confidential human source planned to travel via car to San Diego, California, and onwards to Istanbul by plane in late May. ${ }^{58}$ However, Omar's family caught wind of the plot, and prevented the men from departing. ${ }^{59}$ Undeterred, Yusuf Jama booked a labyrinthian itinerary of plane tickets to test whether he could go to Syria. He "test ran" traveling on June 1, 2014, embarking on a same-day, round-trip journey between Minneapolis and Chicago. ${ }^{60}$ After ensuring that he was not on the no-fly list, he boarded a June 9 flight to Istanbul from John F. Kennedy International Airport in New York. ${ }^{61}$

Yusuf Jama called a family member on June 25, 2014. He would not specify his whereabouts, but told them that he was out of the country. Investigators later uncovered that Jama and Abdi Nur called their families from the same number. ${ }^{62}$ Jama may have been the individual who Mohamed Roble and Guled Omar referred to as "Khattab al-Somali." Evidence also suggests that another co-conspirator, Abdirizak Warsame, contacted one of the Karie brothers to help smuggle Jama into Syria. ${ }^{63}$
In November 2014, five young Minneapolitans attempted to travel to Syria. Their efforts, which failed, demonstrate that they were familiar with the routes taken by Yusuf Jama. Zacharia Abdurahman, Hamza Ahmed, Mohamed Farah, and Hanad Musse planned to take a bus from Minnesota to New York, where they would board flights to Istanbul. ${ }^{64}$ Another route they considered was traveling to San Diego, crossing the border into Mexico, and then proceeding to Istanbul. ${ }^{65}$ This was the same planned route as the first, failed attempt taken by Yusuf Jama and Guled Omar in late May 2014. Reportedly, Omar was so convinced of the San Diego option that he declined to travel with the other four men to New York City. Instead, he attempted to board a flight from Minneapolis to San Diego by himself on November 6, $2014 .^{66}$

When all five men arrived at their respective ports of departure, authorities intercepted them and prevented them from traveling. Guled Omar was asked by federal agents at the Minneapolis airport why he brought his passport for a domestic flight and why he had no baggage, before summarily being prevented from boarding his plane. ${ }^{67}$ This was not Omar's first time being stopped at the airport. In 2012, he was interviewed by the FBI while attempting to travel to Nairobi, Kenya. His older brother, Ahmed Ali Omar, had already joined al-Shabaab 
in Somalia, and investigators were concerned that Guled was planning to join him. ${ }^{68}$

The remaining four (Abdurrahman, Ahmed, Mohamed Farah, and Musse) were apprehended by federal agents at JFK and gave differing and vague accounts of their travel purposes. ${ }^{69}$ More concerningly, while their flights had all been booked within 30 minutes of one another, their itineraries and return flights from Istanbul did not align, alerting federal agents that they may not have intended to return to the U.S. ${ }^{70}$

Ultimately, all five failed travelers were released and allowed to return to Minneapolis, albeit under strict surveillance. A confidential human source recorded conversations and uncovered that all five men, and two others (Abdirahman Daud and Adnan Farah), were attempting to obtain fake U.S. passports in order to travel to Syria undetected. ${ }^{71}$ They also learned that several of the men were in contact with Abdi Nur (and prior to his death, Hanad Mohallim) about how to travel successfully. ${ }^{72}$

Evidence collected by the source details that Guled Omar was still advocating for the fake passports option. The source told Omar that he had a contact in San Diego who could procure forged documents. The other defendants collected photographs of themselves and money to support this venture. ${ }^{73}$ However, Omar, the de facto leader of the group, was concerned that several of his co-conspirators who failed during the NYC attempt in November 2014 would endanger the odds of success. ${ }^{74}$ Omar delayed his own trip to Syria, because he did not want to travel with Mohamed Farah, Zacharia Abdurahman, or Hanad Musse. ${ }^{75}$

Ultimately, the group of willing participants for the San Diego plan reduced to Mohamed Farah and Abdirahman Daud. Mohamed's brother Adnan intended to travel to San Diego, but his mother confiscated and hid his passport to prevent him from leaving. ${ }^{76}$ The two men, and the confidential human source, traveled to San Diego on April 17, 2015. ${ }^{77}$

Days later, several of the co-conspirators were arrested during an FBI operation. Mohamed Farah and Daud were detained in San Diego. Concurrently, Adnan
Farah, Abdurrahman, Musse, and Omar were taken into custody in Minneapolis. ${ }^{78}$ In December 2015, federal law enforcement arrested Abdirizak Warsame, and in February of the following year, Hamza Ahmed became the ninth individual arrested as part of the wider investigation. ${ }^{79}$

The resulting criminal proceedings against these attempted travelers produced a bevy of information about the networks responsible for recruitment to IS in the Twin Cities. The investigation uncovered several successful travelers, multiple attempted travelers, and a handful of others who provided financial support or services to IS. The investigation resulted in six members of the cluster pleading guilty and three convictions by trial, and heralded innovative approaches to how the U.S. government responds to recruitment cases.$^{80}$ Abdullahi Yusuf, one of the first attempted travelers, currently takes part in a program aimed towards rehabilitating jihadists. He was granted supervised, conditional release in November $2017 .{ }^{81}$ The others are serving sentences ranging from two-and-a-half to 35 years in federal prison. ${ }^{82}$

In Syria and Iraq, most of the major players in this mobilization died. In addition to Ahmed, McCain, the Karie brothers, and Hanad Mohallim, Yusuf Jama's brother informed Guled Omar that Yusuf had been killed in battle in Syria in March $2015 .^{83}$ Abdi Nur is presumed dead. ${ }^{84}$ The status of his nephew, Mohamed Roble, remains unclear.

Besides this cluster, there are two other cases of travelers from Minnesota's Twin Cities. Details about potential connections to the previous co-conspirators are not publicly available. In August 2014, 20-year-old Yusra Ismail stole a passport from an unnamed individual, and told the person that she was traveling to a wedding in Africa. She later messaged her family, claiming that she had traveled to Syria to join IS. ${ }^{85}$ Eighteen-year-old Abdelhamid al-Madioum bought a plane ticket from Morocco to Istanbul while on family vacation. After his family returned to the U.S., they received a call from Abdelhamid saying that he was working at an IScontrolled hospital in the Iraqi city of Mosul. ${ }^{86}$ Ismail's and al-Madioum's current whereabouts are unknown. 


\section{Families}

\section{The Kodaimati Family}

Mohamad Saeed Kodaimati was born in Aleppo, Syria, in $1991 .{ }^{87}$ Ten years later, he emigrated with his family to the U.S. By the age of 17 , he became a naturalized citizen. Kodaimati lived in a variety of places in the U.S., including Charlotte, North Carolina, and San Diego, California. ${ }^{88}$

In December 2012, Kodaimati and his family left San Diego to return to their native country. When they arrived in Istanbul bound for Syria, they were detained by Turkish officials for lacking proper documentation. ${ }^{89}$ The Kodaimati family spent 35 days in a Turkish jail awaiting judgment. ${ }^{90}$

They were jailed in the same prison block as an Austrian IS supporter named Mohamed Mahmoud (aka Abu Usama al-Gharib). ${ }^{91}$ Mahmoud is a well-known figure in European jihadist networks. He previously spent four years in an Austrian prison for his role in creating German-language versions of jihadist propaganda material and threatening suicide attacks. $\mathrm{He}$ also played a formative role in the foundation of the Salafi militant organization Millatu Ibrahim. ${ }^{92}$ In March 2013, he was arrested in the Turkish province of Hatay. Like the Kodaimatis, Mahmoud had improper documentation-in this case a fake Libyan passport. ${ }^{93}$ During their time in jail, Mahmoud acted as a translator between the Turkish prison officials and the Kodaimatis. ${ }^{94}$
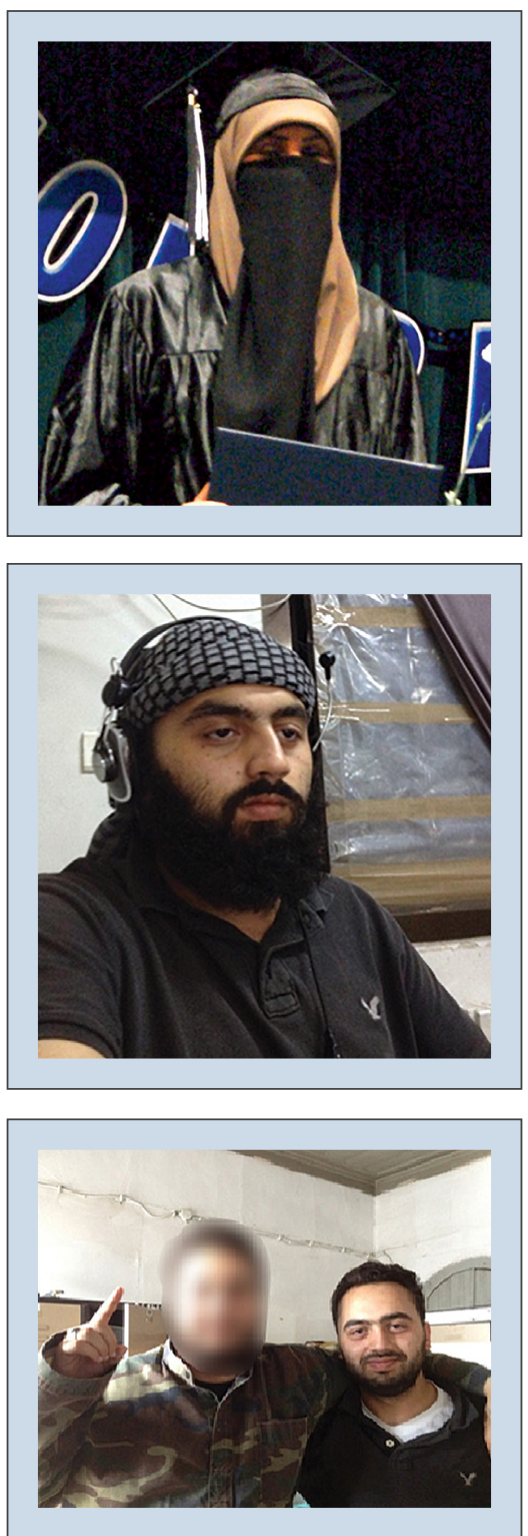

Top: Yusra Ismail at her high school graduation. Image obtained from Minnesota Public Radio. Middle: Mohamad Saeed Kodaimati. Bottom: Individual later identified as Mohamed Mahmoud (L) and Mohamad Saeed Kodaimati $(R)$
After Mahmoud was released in 2014, he traveled to Syria, where he would become a high ranking IS official and a prominent face in the group's propaganda. ${ }^{95}$ Kodaimati and his family were released from jail sometime in 2013. According to Kodaimati's account, the Turkish police escorted them to the "U.S. consulate in Ankara, Turkey," but they were refused admission. ${ }^{96}$ Turkey then deported the entire Kodaimati clan to Syria. ${ }^{97}$

Kodaimati, his younger brother Rahmo, and his father, also named Mohamad, returned to their family home in Aleppo. At the time, the town was a fault line area, split between Assadist forces, assorted rebel groups, and jihadist formations. Their home was in Kafr Hamra, a suburb of Aleppo controlled by jihadist organizations. ${ }^{98}$ After returning to Syria, Kodaimati took a variety of roles in jihadist groupsfirst in JN, then IS.

According to U.S. officials, he was a "media person" for $\mathrm{JN}$, in charge of providing online updates of their operations. Specifically, he worked for the "Sharia Authority," the wing of the group responsible for establishing proper Islamic governance and enforcing the justice system in the area of Hanano. ${ }^{99}$ On his Facebook page, Kodaimati posted several media releases from JN's Sharia Authority. ${ }^{100}$ As IS and JN became increasingly at odds with each other, however, Kodaimati acted as a mediator between the two terrorist organizations. ${ }^{101}$ He obtained this position after he contacted his former jail mate Mohamed Mahmoud, who was already an important figure in IS. 
By his own admission, Kodaimati also participated in fighting, telling one friend, "We went out and participated in a raid, and we struck [with] the ammunition which we possess ... waiting to be resupplied, so that we may go out [again]." 102 According to charging documents, he "admitted that he participated in a diversionary attack on a Syrian political prison in coordination with al-Nusra." ${ }^{103}$

He was not the only one in his family to participate in combat. His father Mohamad, also a U.S. citizen, was injured by shrapnel from a rocket attack. In April 2014, Kodaimati told a friend on Facebook that his father was "on the battlefront ... his work [has to do] with snipers." ${ }^{104}$ The next month, Kodaimati referenced his younger brother, known only by the nickname "Rahmo," and said that he was actively participating in combat as well. ${ }^{105}$ Pictures posted on Facebook also depict Kodaimati's brother and father engaging in combat alongside him. ${ }^{106}$

For his part, Kodaimati states any actions he took in Syria were a matter of survival. He describes his decision as motivated by the unrelenting conflict environment: "if you were male and were clean-shaven, and had good hygiene, you could be accused of being an infidel and killed. If you tried to blend in by sporting a beard then maybe you would be left alone and could pass through checkpoints. Beards became very popular as you can imagine." ${ }^{107}$ In previously unpublished letter written to the trial judge before sentencing, Kodaimati claims: "I am not a terrorist, do not like violence and whatever I did while in Turkey and Syria was necessary for survival.
My family is living in a war zone where they are being bombed by barrel bombs. It is a desperate situation." ${ }^{108}$ He states he tried to find more honest work, and briefly traveled back to Turkey to become a driver for Médecins Sans Frontières. ${ }^{109}$

In March 2015, Kodaimati attempted to travel back to the U.S. He bought a plane ticket for a March 5 flight from Istanbul to San Diego, via Charlotte. However, he was not allowed to board the flight-likely because he had been placed on the no-fly list-and was told to report to the U.S. Embassy in Ankara. ${ }^{110}$ On March 10 and 11, 2015, Kodaimati made false statements during two interviews with FBI and Diplomatic Security Service special agents at the embassy. ${ }^{111}$ At the conclusion of these conversations, the agents told Kodaimati that he was free to go.

Approximately two weeks later, Kodaimati boarded a flight from Istanbul to Charlotte. Immediately following re-entry into the U.S., federal agents stopped him and further interviewed him, but again he was permitted to continue onwards. ${ }^{12}$ Kodaimati drove cross-country to his hometown of San Diego on March 29, 2015. One month later, he was arrested for making false statements to the FBI. ${ }^{113}$

Kodaimati lied about knowing members of IS, his involvement with $\mathrm{JN}$, and his involvement in combat operations. In October 2015, he pleaded guilty to one count of making false statements in an international terrorism case. ${ }^{114} \mathrm{He}$ was sentenced to 96 months in prison the following year. ${ }^{115}$ The current statuses of his brother and father, presumably still in Syria, are unknown.
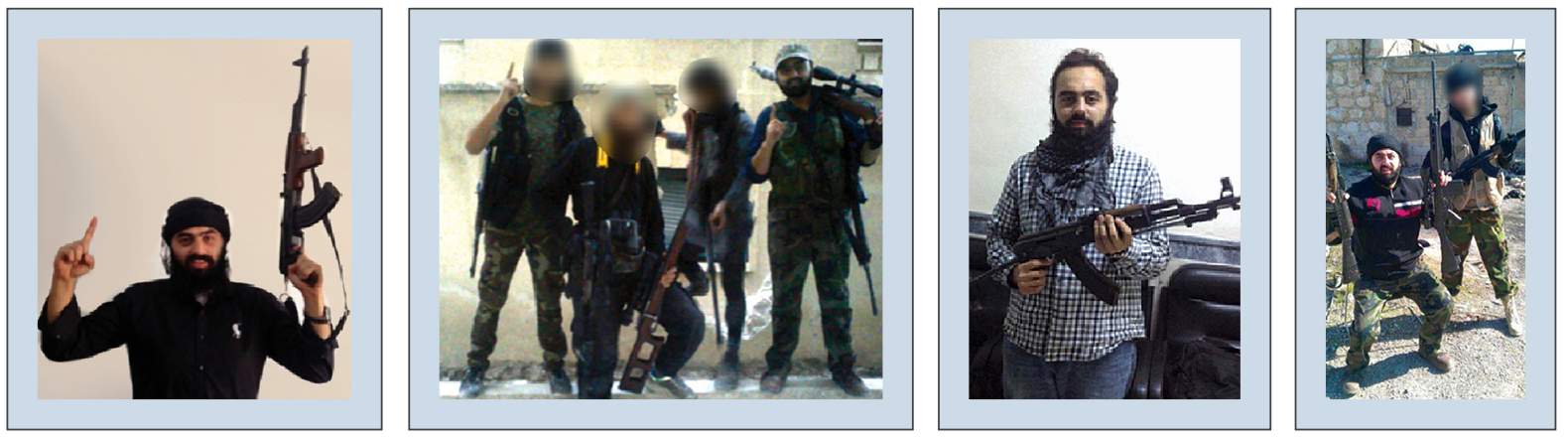

Kodaimati in Syria. Some images reportedly depict Kodaimati's father and brother. 


\section{The Ali Family}

Recently unsealed court documents and a series of interviews with a returned American traveler revealed two brothers from an upper-middle-class Dallas suburb who left together to join IS. The documents came from the trial of the two boys' parents, who misled the FBI regarding their children's whereabouts. Arman and Omar Ali left Cairo, Egypt, where they claimed they were studying, to go to Syria in November 2014. ${ }^{116}$ Federal law enforcement claims that their parents, Mohommad and Sumaiya Ali, "communicated regularly with [Arman and Omar] regarding their whereabouts and desire to fight for ISIS." 117

The elder brother, Arman, attended the University of Texas at Austin from 2008 to 2011, but according to the university, did not graduate. ${ }^{118}$ His classmates at UT-Austin claim that sometime during his second year on campus, he began to espouse radical viewpoints. ${ }^{119}$ After the start of the Tahrir Square protests in 2011, Arman

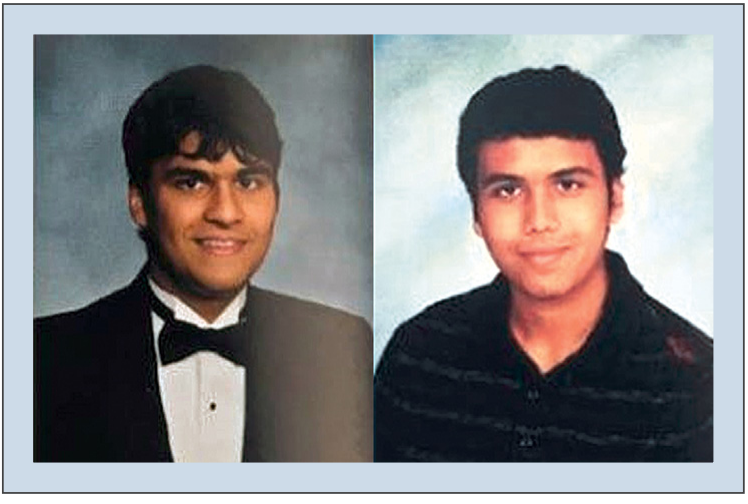

Yearbook pictures of Arman $(L)$ and $\operatorname{Omar}(R)$ Ali. Pictures obtained from Dallas Morning News. to Islam while studying religion at Blinn College, and moved to study Arabic in Damascus months after 9/11. In Damascus, he gained a deep understanding of the classical Arabic language and religious texts. ${ }^{124}$ After marrying his then-wife, Tania, the family moved multiple times between Damascus, London, California, and Plano, Texas. ${ }^{125}$

During the 2000s, Georgelas was an active participant in the online jihadisphere. A data technician by day, Georgelas offered tech support to a variety of jihadist web forums. In 2006, he was arrested for attempting to hack the website of the American Israel Public Affairs Committee (AIPAC) and sentenced to 34 months in prison. ${ }^{126}$ After his release, he remained in the DallasFort Worth area, and it was during this time that he ran the Quran study group.

It is unknown whether the Alis were in contact with Georgelas after their 2011 departures to Egypt, although coincidentally, Georgelas also left Dallas for Cairo around the same time. ${ }^{127}$ In August 2013, John and Tania Georgelas eventually left Austin for

Egypt, where records show he enrolled at the American University in Cairo. ${ }^{120}$ It is unclear what pushed his younger brother, Omar, into joining him in Egypt.

An individual who knew both Ali brothers confirmed, however, that they did not radicalize solely amongst themselves. While they lived in Plano, they attended a semi-regular Quran study group at a local mosque. ${ }^{121}$ The coordinator of the study group was John Georgelas, a young American convert to Islam from Greek Orthodox Christianity. The local imam allowed Georgelas to run the study group, where the Ali brothers became eager students. ${ }^{122}$

Georgelas, also known as Yahya al-Bahrumi, later became a pioneer of the American jihadist mobilization to Syria and Iraq. ${ }^{123}$ Georgelas, a lifelong Texas resident, converted traveled from Egypt to Syria with their children in tow. After a few months, Tania and the children developed serious illnesses. They escaped Syria and returned to the U.S. ${ }^{128}$ Thereafter, John Georgelas became a senior ideological figure and propagandist within IS, potentially the highest-ranking American to have participated in a jihadist group. Georgelas served in the media office, and was reportedly crucial to the production of several IS products, including its radio service, al-Bayan Radio. ${ }^{129}$ He appeared briefly in a June 2017 video released by IS' al-Hayat Media Center. ${ }^{130}$

More than one year after the Georgelases, both Arman and Omar Ali traveled from Cairo to Syria. ${ }^{131}$ Prior to their departure in November 2014, they discussed their plans with their parents. In February 2014, Sumaiya Ali told Omar to "do what you need to do," to which Omar 
responded, "Ok then going to Syria it is." 132 A month before their departure, Arman Ali emailed his father a video of an IS military parade in Libya and discussed other Americans who traveled to join IS. ${ }^{133}$

As soon as the brothers entered Syria, conversations with their parents took on a different tone. In March 2015, Arman Ali emailed his father:

... things are heating up here, and I can't guarantee me or O[mar] will be there in 2 months. Don't tell [mom] or anyone else this, I've been to the hospital everyday with brothers from my group. Close friends have died, too many injured. Me and $\mathrm{O}$ [mar] $\mathrm{r}$ perfectly fine right now, but soon we may not be. ${ }^{134}$

Two months later, federal investigators interviewed Mohommad and Sumaiya Ali. Both parents claimed that their sons were still in Cairo, and that their sons were "peaceful," "liked to study," and were not affiliated with terrorist groups. ${ }^{135}$ In May 2017, two years following this interview, federal prosecutors charged both parents with making false statements in an international terrorism case. ${ }^{136}$ In September 2017, both parents pleaded guilty. According to the terms of a sentencing agreement, they will serve 36 and 18 months of probation, respectively. ${ }^{137}$

This case highlights a critical dilemma facing travelers' families. They have the option to turn in their family members to federal authorities, which could subject them to decades-long prison sentences. Alternatively, they can try to take justice into their own hands to prevent family members from traveling (like Asher Abid Khan's parents) or lie to protect them (like the Ali brothers' parents). While families can be instrumental in fostering radicalization or facilitating travel, they can also serve as critical early warning systems to notify appropriate authorities. ${ }^{138}$ However, as it stands today, there are few good choices for those who want to intervene to prevent their family members from traveling. ${ }^{139}$

\section{Friends}

The concept of a networked terrorist group formed by small, close circles of friends remains an important conceptualization of how radicalization and mobilization occur in the West. ${ }^{140}$ According to this formulation, initially postulated in the years following $9 / 11$, the majority of jihadists were not radicalized via a top-down process, but as the result of small friendship groups that progressively convinced them to support jihadist organizations. ${ }^{141}$ Certainly, this formulation should not be used as a sweeping motive to explain the radicalization of all Western jihadists. In its original terms, however, it can be useful in analyzing specific cases on their merits.

In the dataset, several cases appear to fit this description of jihadist mobilization. In some cases, not enough is known about their radicalization process to assume that it occurred solely in a friend-group setting. However, in each of these cases, Americans were progressively encouraged to travel, and eventually facilitated their travel, through a small group of friends. The size of the group may range, from two friends to several. They also sometimes involve "friends-of-friends" or online contacts. Throughout these cases, however, friendship groups help facilitate an American's travel to join a jihadist organization in Syria and Iraq.

\section{Sixto Ramiro Garcia and Asher Abid Khan}

A combination of online and offline connections assisted two young Texans in planning their travel. In January 2014, 20-year-old Asher Abid Khan sent a Facebook friend request to one of his friends from his mosque back home in South Texas. ${ }^{142}$ At the time, Khan was living with a relative in Australia. The recipient was Sixto Ramiro Garcia (aka Abdullah Ali) a Mexican-American convert to Islam. Khan and Garcia were reportedly close friends before Khan's departure to Australia, and the two used to watch extremist videos together when they both lived in Texas.

After Garcia accepted the friend request, Khan sent him a message stating that he was interested in traveling to Iraq to join IS. ${ }^{143}$ The two Texans then triangulated a plan to join the organization-one from Texas and the other from Australia.

A week later, Khan sent another friend request, this time to Mohamed Zuhbi, a well-known Australian IS 
supporter and alleged facilitator. Khan messaged Zuhbi: "I'd like to join ISIS, can you help?"144 The conversation progressed, with Khan expressing his willingness to "die as a shahid [martyr]." During the conversation, Zuhbi systematically walked Khan through the process of traveling to join IS. He told Khan to take a flight to Istanbul and proceed via bus to the Turkish-Syrian border town of Antakya. ${ }^{145}$ From there, IS smugglers could meet Khan and escort him across the border.

A week after his conversation with Zuhbi, Khan relayed the information to Sixto Ramiro Garcia on Facebook and offered to print his Turkish visa out for him. The three-way transfer of information from Zuhbi to Khan, and Khan to Garcia, also continued. Khan asked Zuhbi a host of questions, including what kind of sim card to buy in Turkey to contact Zuhbi, which plane ticket Garcia should buy, and whether he should trim his beard before travel to avoid suspicion. ${ }^{146}$

On February 23, 2014, Garcia traveled from McAllen, Texas, his hometown, to Houston. ${ }^{147}$ From there, he boarded his flight to London, en route to Istanbul. Garcia was nervous about the plan. Before his departure, he texted Khan: "If I could, I would destroy all the butterflies in my stomach." ${ }^{148}$ Khan attempted to reassure his friend: "lol, bro, chil and have fun. This is an experience so enjoy and learn from it." Khan reminded Garcia about their cover. "You're a tourist and tourist are never nervous, they're curious." 149

Khan also departed from Syria on February 23. He left his relatives' house in Australia with tickets to Istanbul via Malaysia. However, Khan did not complete the journey. When he arrived in Kuala Lumpur, his Australian relatives tipped off his parents, who attempted a last-minute effort to prevent their son from joining IS. ${ }^{150}$ Khan received a message from his parents claiming that his mother had been hospitalized. This was not true, but the ploy convinced Khan to abandon his plans and return home to Texas. ${ }^{151}$

Garcia, meanwhile, continued on his journey. On February 24, Khan informed Garcia that he was returning home to Houston to be with his family. Garcia was incensed by his friend's change of heart. "Dude, you can't pull [expletive] like that. I didn't come with all that much cash. I have no connections. I've got no clue, WTF."152

Seemingly feeling indebted to Garcia for encouraging his travel without following through on his own, Khan connected Garcia with Zuhbi and asked for help getting Garcia through the border into Syria. Garcia and Zuhbi exchanged a series of messages. "Please pick me up. Im in the bus station [at] Antakya. Call me ... I tried calling your number but I think I'm missing some things. There's guys asking me if I'm [trying] to go to Syria." ${ }^{53} \mathrm{Zuhbi}$ responded, "Go to a hotel. Hotel Antakya is preferred." Finally, after some back and forth, the two men agreed to meet at a local mall. "Ok, I am wearing white glasses on top of my black hat, blue sweater white Jordan's and black pant, a very shirt under my sweater.”154

Three days after Garcia arrived in Turkey, he crossed the border into jihadist-controlled territory. He told Khan he had "been delivered :)"155 Over the course of the next few months, Khan and Garcia continued their online communications. Garcia provided him with a play-byplay of his experiences, claiming he was in a boot camp and had an "ak" (AK-47) that he had fired. He also stated he was involved in battles, a "lil bit." ${ }^{156}$ From February to August 2014, Garcia was part of a jihadist group not affiliated with IS. He sent Khan pictures from Syria, including an AK-47: "that's my baby ... you can have one too if you like."157

Finally, in August, Garcia messaged Khan, noting that he had finally joined IS. ${ }^{158}$ This was the last conversation that Garcia and Khan ever had on Facebook. At its conclusion, Khan told Garcia to "make sure they [e.g., IS] are doing everything according to Islam, not killing innocent ppl and all that." ${ }^{159}$

Shortly following Garcia's arrival in Syria, his concerned family members contacted the FBI, and a formal investigation commenced. ${ }^{160}$ The Bureau obtained a search warrant for Garcia's social media accounts, which led them to uncover his connections with Khan. This scrutiny intensified when Khan filed another visa request to travel to Australia in October 2014. Investigators were concerned that he intended on following through with his plans to go to Syria. ${ }^{161}$ 
On December 25, 2014, Garcia's family received a message from his Facebook account. An unknown IS member informed them their loved one was dead. ${ }^{162}$ Khan was arrested five months later. He recently pleaded guilty to providing material support to IS. ${ }^{163}$

\section{Brian Dempsey and Terry Ingram}

In May 2015, federal investigators filed a criminal complaint alleging that Brian Arthur Dempsey, Sr., a 43-year-old resident of Sacramento, California, had made false statements to federal authorities in an international terrorism case. ${ }^{164}$ Dempsey's case is an anomaly in multiple regards. First, Dempsey is one of the oldest travelers in the dataset, one of two individuals over the age of 40 . He lived in the Sacramento area until July 2013, when he initially went to Syria. Moreover, Dempsey was a sworn California peace officer until 2012. He served as a youth counselor for the California Department of Corrections and Rehabilitations for over a decade. ${ }^{165}$ At some point prior to his travel to Syria and Iraq, likely between 2011 and 2013 , he converted to Islam. ${ }^{166}$

The complaint alleges that Dempsey and another individual, referred to as "Person A," conspired to travel to Syria in July 2013 to "participate in combat." ${ }^{167}$ Dempsey only stayed in Syria for a month and a half, before attempting to return to the U.S. via Rome, Italy. ${ }^{168}$ Unfortunately for Dempsey, he had already been added to the U.S. no-fly list. As a result, FBI agents stopped and questioned him at the airport.

During the August 22, 2013, interview, Dempsey lied to the FBI about his time in Syria, most of which he spent in the border town of Azaz. He told special agents that he traveled to Syria with Person A to "help refugees" and that he asked his brother to call the State Department to ensure that entering Syria was legal. ${ }^{169}$ Moreover, he claimed not to know any members of terrorist organizations, and that no one in Azaz was fighting the Syrian regime. ${ }^{170}$ According to Dempsey's story, they had no opportunities to help refugees; the only thing he and Person A did in Azaz was "hang out."

After this interview, Dempsey canceled his return to the U.S. and remained in Italy. Internal law enforcement documents show that Dempsey was on an official list of foreign fighters compiled by the Italian government. ${ }^{172}$ In January 2014, U.S. law enforcement interviewed Dempsey again in Rome. During this interview, he made multiple statements that disputed claims he made during the airport encounter. Dempsey admitted that he had traveled to fight, and also that he had contacted members of several jihadist organizations in Azaz, including IS, JN, and Ahrar al-Sham. He also claimed to have engaged in combat on at least two occasions during his stay in Syria. ${ }^{173}$

U.S. authorities were planning to resolve the charges against Dempsey in exchange for cooperation, but in October 2014, Dempsey absconded from Italy. ${ }^{174}$ Subsequently, law enforcement filed criminal charges against Dempsey for making false statements. ${ }^{175}$ Dempsey, meanwhile, traveled to Germany, and then onwards to the United Kingdom (UK). His exact itinerary remains unclear, but in January 2017, he was arrested in the UK. Extradition proceedings are pending. ${ }^{176}$

After Dempsey's departure from Syria in August 2013, Person A stayed in Syria. A source with knowledge of the investigation confirmed to the authors that Person A refers to Terry Ingram, another Sacramento resident and convert to Islam. ${ }^{177}$ Ingram's whereabouts are unknown, but the source also remarked that Ingram was far more "radical" than Dempsey, and likely joined either IS or JN after Dempsey's departure. ${ }^{178}$

Ingram took an unusual path towards jihadism. In the early 1990s, a group called the Juris Christian Assembly (JCA) formed in Stanislaus County, California. The group's name was somewhat of a red herring. Its main purpose was to protest tax laws and it ascribed to what can now be generally termed as a "sovereign citizen" ideology. ${ }^{179}$ In short, Juris Christian Assembly's members believed that they were not subject to state taxes, because they were "free Christian Israelite Citizen[s], not resident[s] of the forum state, the corporation referred to as 'the State of California."'180

As members of the group refused to pay taxes, they accumulated hundreds of thousands of dollars of back taxes, and the Internal Revenue Service (IRS) placed liens on 
their holdings. ${ }^{181}$ In response, the group's leader and several members, including Terry Ingram, conspired to defraud the government by filing fraudulent warrants for IRS officials and intimidating government employees. ${ }^{182}$ In January 1994, group members assaulted and threatened to kill the Stanislaus County recorder. ${ }^{183}$

Ingram participated in the JCA plot by filing false warrants to an IRS center in Fresno, in the amounts of $\$ 12,550.48$ and $\$ 1,238.94$. Two other members also went to his place of employment, a local car dealership, and demanded that Ingram's wage levies be removed while posing as federal government employees. ${ }^{184}$ In June 1995, Ingram and several others were indicted on several fraud counts, as well as the attack on the county recorder. Ingram was found guilty and was eventually released from prison in 1999. ${ }^{185}$

Given the lack of publicly available evidence about these cases, it is especially hard to determine how a former correctional officer and a former "sovereign citizen" who both converted to Islam met one another, and decided to travel to Syria to fight. Dempsey's eventual extradition and prosecution in the U.S. may bring more details to light. However, these cases are reminders that the social connections that influence travelers are not always straightforward or conventional.

\section{Networked Travelers: Why "Strength in Numbers" Matters}

As noted previously, dozens of academic studies found that previous face-to-face interactions with fellow travelers are a strong determinant of mobilization. In some cases, these connections and social bonds extend beyond the decision to travel. Some studies point to the effect of small group interactions on their members' progressive adaptation of radical viewpoints. ${ }^{186}$ This thesis is difficult to prove conclusively. Radicalization is a complex process. What holds true in one individual's case may not hold in another. Like other travelers, the motivations of networked travelers vary, from those who originally went for familial reasons to others enticed by a greater jihadist narrative that depicted life in a utopian Islamic society.
The majority of travelers in our sample established close connections to other American travelers, and supporters of jihadist groups more broadly, prior to their travel. Some reached out to individuals online who self-identified as facilitators or smugglers into jihadist controlled territory. They plugged into a wellworn network of jihadists who provided step-by-step directions on how to fool customs officials, which hotels to stay in, and who to call once they reached the Syrian and Iraqi borders. They augmented that knowledge and connections with their offline relationships, leaning on deep social connections to plan and execute their international travel. In many cases, it is not clear that these individuals would have successfully traveled to Syria and Iraq without the help of these real-world connections.

However, some individuals learn the difficult lesson that connecting to other jihadist sympathizers is insufficient for successful travel. Strikingly, the same networks (friends, families, and social groups) served as roadblocks in some cases. If certain friends or family members uncovered a would-be traveler's plans, their travel attempts unraveled. Asher Abid Khan, for example, made all the contacts necessary to smuggle his friend, Sixto Ramiro Garcia, into Syria. But, when his parents discovered his plans, they prevented him from making the journey himself.

Including more people in a travel plot can backfire. During their final attempt to secure fake passports and travel to San Diego, the Minneapolis attempted travelers grew increasingly paranoid. Several cluster members pulled out of the group because they didn't trust members who made previous, unsuccessful travel attempts. Guled Omar eventually became so frustrated with some of his co-conspirators that he told another group member, "I don't want to travel anywhere with them ... I feel like if I go anywhere with them it's a failure." ${ }^{187}$ The feeling was not limited to one member-Zacharia Abdurahman pulled out of the plan days later, fearing that the number of people involved increased the likelihood that law enforcement would interdict the plot. ${ }^{188}$ Ironically, both Abdurrahman and 
Omar confided their distrust of other group members to the FBI's confidential human source.

External interventions or internal rifts between group members provide law enforcement a window to disrupt travel facilitation networks. Oftentimes, law enforcement was notified by concerned family members or friends. Sometimes, attempted interventions happened too late, occurring after the individual already traveled. However, when there was a network behind that individual, input from family members and friends helped law enforcement identify other travelers and attempted travelers. Moreover, law enforcement frequently used confidential human sources to infiltrate small group plots to facilitate travel. Prosecutors in the Minnesota cluster cases owed a significant degree of their success to evidence attained from confidential sources.

Nevertheless, building social contacts allow travelers to generate a "Hydra effect." Law enforcement may apprehend a few travelers, but several more will slip through the cracks and reach their destination. In general, deep-seated connections lower the probability that external forces will intercept travelers. For instance, Mohommad and Sumaiya Ali were willing to mislead the FBI, facing up to eight years in prison, rather than tell investigators that their sons had traveled to Syria and Iraq to join IS.

Moreover, connections make it easier for group members to share technical and logistical information about how to travel. Mohamed Roble drew on the successes and failures of Abdi Nur and Abdullahi Yusuf's respective attempts to travel, taking a route that would not immediately alert authorities. In several of the aforementioned cases, including Garcia, McCain, Nur, Mohallim, and Jama, travelers relied on pre-established social connections to contact smugglers and facilitators who could help escort them across the border into Syria and Iraq.

Another valuable lesson from networked travelers is that successful travel often has a serendipitous element. Abdi Nur and Abdullahi Yusuf were similar in many ways: both were young Somali-Americans from Minnesota who wanted to travel to IS, pursued the same course of action, received their passports within the same week, and traveled one day apart from each other. More importantly, Yusuf had a stronger link to the network than Nur, as Hanad Mohallim was his best friend. However, Yusuf botched his passport application interview, and Nur did not. A senior law enforcement official involved in the investigation later recalled that without the suspicions raised during the interview, Yusuf might never have been apprehended. ${ }^{189}$

The one known exception to the norm of American traveler networks is the Minnesota cluster. Unlike its counterparts, which usually involve isolated groups of two or three members, the Minnesota cluster transcended several friendship and family groups and included at least 15 people directly. The 2007-2013 recruitment wave to Somalia entailed that the new generation of jihadist recruits had access to organized formations of jihadist travelers, with experience, knowledge, and skills that could be used in future recruitment. It is no coincidence that upon arrival to Syria, Abdi Nur reached out to Somaliabased Minneapolitan Mohamed Abdullahi Hassan for guidance. Several other co-defendants had family and friendship connections to al-Shabaab members. Drawing from this structure, and the charismatic personalities it produced, the Minnesota travelers formed tight-knit kinship and friendship groups to facilitate their travel.

These clusters are less frequent in the U.S. context than in other settings. Nevertheless, the majority of successful American travelers had some form of network behind them. These webs were based on social connections with friends, family members, and community groups, and were used to facilitate travel. Beyond those factors, networks vary from case to case. Some involved external contacts (e.g. Mohamed Zuhbi); many used digital communications technologies to augment existing personal contacts. Networks vary in size, but the majority comprised of small groups of two, three, or four people. Despite the diversity of network types, these findings are in line with much of the current research on the role of personal connections. ${ }^{190}$ 



\section{Category 3: Loners}

$\mathrm{O}$ the cases analyzed in this report, loners are the least common. The term describes travelers whose motivation to join does not appear to have come from any face-to-face interactions, and whose journey was seemingly undertaken in isolation.

According to publicly available evidence, these individuals only became known to authorities after successfully joining the group and either turning themselves in, appearing in publicly released propaganda, or having their deaths on the battlefield announced or reported by the organization to the media or their families.

This section will analyze the cases of two American loners. The first, who will be referred to only as "Mo," traveled to IS territory in June 2014, before turning himself in at a U.S. consulate in Turkey in November of the same year. Much of the data from this case was gathered during an interview between the authors and "Mo."

The second case is that of Mohamad Jamal Khweis. In December 2015, he left his home in North Virginia to join IS, stayed with the group for almost three months, and eventually turned himself in to Kurdish forces in March 2016. Here, the authors rely on court documents from the case, the prosecution's exhibits used for evidence, and notes taken by the authors during his trial. ${ }^{2}$

\section{"Mo"}

Mo was one of the first Americans to travel to Syria, leaving his home on the East Coast in June 2014. In a lengthy interview with the authors, he laid out some of the factors which motivated him to join IS, while also providing insight into how he made the journey and what he saw while with the group.

While his story helps to explain why some young Western Muslims are captivated by IS' cause, those hoping for a simple explanation will be disappointed. When asked why he joined IS, Mo rejected the premise of the question, responding, "You should ask me why did I go there [to Syria].” To him, joining IS was an afterthought-he had no strong ideological affinity specifically to the group. He was, however, drawn to its wider project: "I went because I wanted to live in a sharia environment."

\section{Motivations}

Mo traces the roots of his decision to what he describes as a "catalyzing moment" in 2013 when, while studying at a major American university, one of his professors screened a video of Submission. Released in 2004, the provocative film by the late Dutch director Theo van Gogh depicted a woman wearing a see-through burqa with Quranic verses tattooed on her body. The film represented a touchstone moment in the story of Islam in the West after 9/11. ${ }^{3}$ It gained even more notoriety after van Gogh was murdered in the streets of Amsterdam in 2004 by Mohammed Bouyeri, who supposedly acted to avenge and preserve the honor of Islam. ${ }^{4}$

Mo was shocked and angered by what he saw, explaining that "the burqa is the ultimate symbol of virtue and purity, members of my own family wore it. I didn't see it as purely offensive, but a desecration." He began to see the concept of freedom of speech in a different light: "This idea of freedom of speech was being used to desecrate."

He was also shocked and disappointed at the reaction of his fellow students: "I looked around the classroom and everyone was just watching like it was nothing." $\mathrm{He}$ took this as a tacit approval of the themes of the film, and began to see his peers in a different light. While he wanted to stand up and express his anger, Mo stayed quiet, explaining, "I was not intellectually equipped to properly criticize this, I didn't know how to make sense of it or explain it." This feeling spurred him on to further educate himself. He soon took to the internet in an effort to learn how, as a Muslim living in America, he should respond to the attitudes expressed in the film.

While it would be simplistic and incongruous to draw a direct link between this film and Mo's journey to IS, it 
appears to have started him on a path which resulted in a significant transformation in his identity and beliefs. Religious but not very observant at the time, Mo now began to seek out a clearer understanding of his religion and what answers it had to the issues brought up in the film. This made him vulnerable to the type of propaganda being produced by IS at the time, which specifically targeted Western Muslims who were dealing with crises of identity and struggling to figure out where they fit in their home countries. ${ }^{5}$

However, this was a formulation which Mo did not entirely accept when put to him, rejecting what he saw as an attempt to "put me in this box and explain my decisions... it's not that simple." Radicalization cannot be explained using any single "moment" or root cause. ${ }^{6}$ However, for researchers, it is important to identify patterns that may contribute to a more informed understanding of this phenomenon, while also acknowledging the layers of unquantifiable complexity involved in influencing personal decisions to join extremist groups.

Alongside this possible religio-political awakening, Mo also mentioned an experience of personal trauma. Years earlier, his pregnant sister and her unborn child died in tragic circumstances. Here, too, it is tempting to turn yet again to academic theory: perhaps a traumatic moment that could be seen as a so-called "push factor" in his radicalization process. Mo rejected this too, noting that the deaths occurred almost eight years before he joined IS. Nonetheless, it was telling that Mo found this story relevant enough to bring up in a discussion framed around his radicalization. Even more interesting was his claim that the woman in the burqa which so offended him in Submission reminded him of his sister. Without proper evaluation, one can only wonder about the kind of psychological impact this might have had on him.

From the moment he had watched the film, Mo claims that his "main source of learning was online." He spent hours researching Islam and politics, and began developing a stronger sense of his religious duties as a result of his online consumption. The work of American-Yemeni al-Qaeda ideologue and recruiter Anwar al-Awlaki was particularly impactful. ${ }^{7}$ Mo came to see him as a legitimate source on Islam due to the multitude of sermons he gave while preaching in the U.S. He started becoming much more aware of the fact that, as he saw it, "Muslims have political woes" and as a result, "became more interested in groups out there that were defending Muslims and also in living in a place where Islam was being properly implemented."

Mo soon concluded that the U.S., and the West in general, was not a place any "real" Muslim could live. Countries where films like Submission were created and screened could not be the right environment for a Muslim wishing to observe their religion properly. $\mathrm{He}$ also became more aware of his wider social and moral environment. He grew squeamish at the depictions of scantily clad Victoria's Secret models outside of its store in New York, particularly when thinking about how he would react to such images in the presence of his young female family members: "How can I explain that to my young cousin or niece looking at that? That is objectifying women, no doubt."

Relatedly, among the concepts he became acquainted with through his online research was hijrah, or migration for the sake of Islam. The term hijrah has multiple interpretations depending on the brand of Islam one ascribes to, and for many Muslims, it is a largely irrelevant concept for the modern world. ${ }^{8}$ For some, hijrah refers to leaving one city, or even a specific neighborhood, deemed to be harmful to one's faith for a more conducive environment. At its most extreme, hijrah has a militant expression. Jihadists describe hijrah as not only leaving Western nations deemed to be part of the war on Islam, but also traveling to an area to fight in defense of Muslims who are perceived to be "under attack." IS propaganda outreach to Westerners has placed great emphasis on hijrah to the battlefields of Syria and Iraq as a duty for Western Muslims. ${ }^{10}$

Mo's understanding of hijrah fell somewhere in between these two interpretations: "For me, hijrah was about leaving a place where haram (things forbidden in Islam) was easy and halal (things that are permissible, or even encouraged, in Islam) was difficult." He began to feel that this was precisely his situation in America: 
"Some Muslims are fine living here, and find ways to live a proper Islamic life, but at that time I was not one of them."

Not only did he begin to see those Victoria's Secret models in a new light, but he also became aware of the "sins" of the Western financial system. For instance, Mo believed he "could not take part in" loans with interest rates, which constituted riba (usury), considered a sin in Islam. Previously, he was happy to take interest-heavy student loans to pay for his tuition. Now, he was so vehemently opposed to riba that he dropped out of college rather than accepting money tinged with sin.

Thus, what began as a perception of increased scrutiny and criticism of Islam in the West rapidly evolved into a drastic personal transformation. Influenced by Islamist propaganda, Mo resolved that he had to depart his country of birth. He also described being inspired by the Arab uprisings: "After the Arab Spring, Muslims were finally getting rid of the dictators." For him, this meant that there was now more scope for states to govern according to sharia law.

It is also revealing that, once he decided to make hijrah and leave America, Mo claimed that IS territory was not his first destination of choice: "that was, of course, Saudi Arabia." He believed that the Kingdom offered the purest version of Islamic life, and planned on enrolling in the University of Medina. However, his knowledge was not advanced enough. Besides lacking other basic requirements to matriculate in the university, Mo was not able to recite a sufficient number of Quranic verses.

His dreams of living in Saudi Arabia dashed, Mo began considering other options. Many associate IS propaganda with the graphic and violent depictions of the group's punishments of its enemies. Yet, at the time, a substantial amount of its media output focused on the depiction of its territory as the only true Islamic utopia, where sharia law was properly implemented, and Muslims were thriving. ${ }^{11}$ "There were all these videos showing the public works IS was taking part in, it looked like a good Islamic community to raise a family." At the time that he was researching the group, the first wave of the most infamous videos, such as the brutal beheadings of the American journalists
James Foley or Steven Sotloff, had yet to be released. "The effort of IS as I saw it was Islamic government, and that's what I wanted."

At best, Mo's idealized depiction of IS certainly displays a level of naïveté. At worst, he was fully cognizant of IS' violent nature. Most discerning observers at the time had already identified IS as a jihadist group with its roots in AQ franchises in Iraq. Nonetheless, Mo's outright rejection of Western media and any non-Muslim analysis of the Syrian conflict convinced him to turn a blind eye to IS' flaws, while taking their propaganda at face value.

Mo claims he was not aware that IS was a group that was "like al-Qaeda," and notes that he had already rejected al-Qaeda because he was against the group's use of suicide bombings after learning online that this tactic contradicts sharia law. The justifications put forth by jihadists for suicide bombing, which draw upon analogies from a handful of Quranic verses and stories from the Hadith, did not convince him. In fact, in a display of some level of Islamic knowledge, he described these

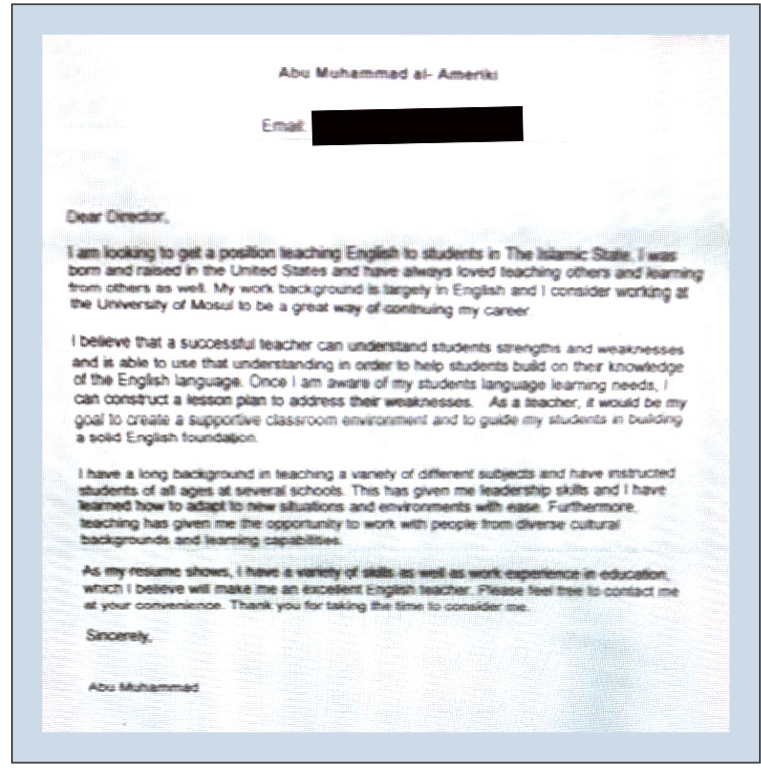

Mo is not the only American who sought a non-combat role in IS. This is a copy of a cover letter from Warren Clark (Abu Muhammad al-Ameriki), attached as part of his application to become an English teacher for IS. The application was retrieved from a house in Mosul, Iraq, and exclusively obtained by the authors. 
justifications as qiyas maal fariq (analogy with discrepancy). This is a term used by Islamic scholars who reject the religious rationale for suicide bombing used by jihadists.

Suicide bombing and its permissibility is, at its core, an issue of Islamic jurisprudence, or figh. Through a process of deductive analogy (qiyas) in which the primary texts of Islam are studied, compared and contrasted, Sunni Islamic scholars of figh create injunctions on how Muslims should deal with new circumstances. ${ }^{12}$ The figh of suicide bombing encouraged and spread by jihadists is rejected along these lines and seen as merely a way of trying to take attention away from the fact that it is an act of suicide, which is a major sin in Islam. ${ }^{13}$

It was on this basis that Mo claimed to reject al-Qaeda in favor of IS. "Al-Qaeda put me off, I was always against terrorism and especially suicide bombing." In spite of the numerous reports detailing IS' use of suicide attacks, he appears to have thought IS was different. "As far as I could see at the time, IS was not the same as AQ, the effort of IS was Islamic government and that's what I wanted. It felt legit, and the clue was even in their name!"

\section{Journey}

Once he had begun to embrace IS, Mo started to follow influential members and supporters of the group on Twitter, a platform he found particularly useful as it allowed him to receive news of the group's activities "straight from the source." As he followed and read about the experiences of fellow Americans and other English-speakers in Europe who joined IS, the prospect of traveling to Syria soon began to feel more realistic. It was not as hard as it first seemed: "I knew from following these guys that the border [between Syria and Turkey] was porous, and that Urfa [Şanlıurfa, a Turkish town near the Syrian border] was the place to go."

His online activities quickly caught the attention of the authorities. Concerned that he was preparing to travel to Syria, FBI agents from the Joint Terrorism Taskforce interviewed him in early June 2014. "When they came to visit me, all of a sudden it became real. It wasn't just something on my computer anymore.” During a consensual interview, Mo claimed that he supported rebel groups in Syria, but did not have the means, knowledge, or wherewithal to travel. In truth, however, the FBI visit simply added more urgency to his plans: "The train now felt like it was leaving the station, I had to either go soon after that or not at all." Just a week after the interview, on June 12, 2014, he booked a flight from New York to Italy. This journey included a stopover in Istanbul in the hope that it would mask his intentions to remain in Turkey and go on to Syria. As an illustration of his commitment to join, at the time of his trip he was recovering from an ankle injury and needed crutches to walk. Yet he was still willing to brave the rough terrain of southern Turkey and northern Syria.

Upon arrival in Istanbul, Mo immediately made his way to Şanlıurfa. Surprisingly, prior to his arrival, he had not made contacts or connections with members of IS or the smugglers who would help him cross the border and join the group. He relied instead on finding the right people once he was in the town or, if all else failed, "even just go there and cross by myself." By then, he had also come across a famous pro-IS Twitter user who went by the handle @Shamiwitness-at the time, this was the group's leading online "fanboy." Authorities in India later connected this account to Mehdi Biswas who, tweeting from Bangalore, was eventually arrested in December 2014 in India for glorifying IS. ${ }^{14}$

While analysis of @Shamiwitness' activities to date paint him merely as a propaganda disseminator for IS, it seems that his role may have in fact also been one of direct facilitation for would-be Western travelers. While in Şanlıurfa, Mo used Twitter to reach out to @Shamiwitness, who put him in touch with three local IS facilitators, including a British IS member called Abu Rahman al-Britani. Using Kik, the encrypted messenger of choice for IS travelers at the time, he reached out to al-Britani. Mo was then given a number for an IS smuggler and told by al-Britani that he could use him for tazkiya, a vetting process whereby a known fighter vouches for a new member to other IS members. ${ }^{15}$

He eventually agreed with the smuggler on where and when to meet. That night, he was picked up outside of his hotel and taken to a safe house which held other 
travelers including what he claimed was a Russian former neo-Nazi convert to Islam. ${ }^{16}$ After a few hours, they were taken in a car across the border into Syria and dropped off-"he [the smuggler] pointed to Orion's Belt and told us to follow it until we came to a village." Mo was still limping in his surgical boot from his ankle injury (he had left his crutches behind) as they trekked over rough terrain to reach the village. In the process he and his fellow travelers were arrested by Turkish border guards, beaten up, and briefly detained before being released for reasons that remain unclear. Post-release, the group eventually arrived at the village. From there, they were picked up by men claiming to be with IS and moved to another safe house in Suluk, a Syrian town about seven miles south of the border with Turkey.

\section{Mo in Syria}

During his two-week stay in Suluk, dozens of travelers from a variety of countries joined Mo. While staying in the safe house, Mo claims that he began to harbor serious doubts about the choice he had made to travel to Syria. Hoping to find a welcoming group of "brothers" he could join, he was quickly disappointed: "They weren't the type of Muslims I grew up with.” Mo referred to them as lacking in akhlaq, which translates directly from Arabic to "disposition," and refers to the strong moral and virtuous character of a person. The fraternal bonds and camaraderie among travelers, so often highlighted as motivating factors for those who join jihadist groups, did not exist in the way he expected: "They prayed differently, they had a bad attitude towards sharing food, they weren't doing $w u d u$ (ritual ablution before prayer) properly, and the bathrooms were kept terribly."

Mo also claims that he never traveled to IS territory with the intention of fighting. Instead, he hoped to start a new life in the sharia environment he had come to yearn for: "I wanted to maybe start a business and eventually raise a family." When, during his time in Suluk, an IS member brought a suicide vest for the new members to become familiar with, he began to see the group in a different light. He also became concerned for his safety. After evening prayers, the man also gave a speech to the group about suicide bombing, claiming IS supported it despite being qiyas maal fariq. Mo, having already explained his rejection of the practice on these terms, was shocked: "They know it is legally weak, but they still accepted it, and he told us that "we gain benefit from it, so we do it."

As time went on, Mo claimed to grow increasingly despondent about his new home. After losing his glasses during the scuffle with the Turkish border guards, he was unable to get a good view of his wider surroundings until a fellow recruit lent him his pair. "That was the first time I got a full view of where I was-just this desolate desert-I felt hopeless and thought 'how the hell do I get back home from here?!" He was also able to speak to his parents using a burner cell phone which was passed around by the recruits, only increasing his feelings of regret and homesickness.

Other English speakers in Suluk were a mix of people, both those having second thoughts, like Mo, and more committed, hardcore jihadists. In the former category was someone he knew as Abu Salman al-Hindi. This was the kunya of Talmeezur Rahman, an Indian national raised in Kuwait who attended a university in Texas between 2012 and 2014. ${ }^{17}$ His story has been reported in the media, though his current whereabouts are unknown. A trained computer scientist, Rahman hoped to offer his technical expertise to IS, but soon found out he would have to fight; like Mo, he was intent on avoiding the battlefield. Mo and Abu Salman bonded over their shared fate and became friends: "Salman was one of the only guys there I could relate to."

Mo claimed that other American recruits were more fervent in their beliefs and their desire to fight. After Mo spoke to his parents, a Somali-American from Minneapolis named "Omar" accosted him. ${ }^{18}$ "He asked me how strong my parents' Islam was, and if I had made takfir on [excommunicated] them." An uncompromising hardcore jihadist ideologue committed wholeheartedly to jihad, Omar represented the other end of the spectrum of the Western IS recruits in Suluk at the time. Indeed, according to Mo, "most of the Americans I met during my time in Syria were very ideological and ready for fighting."

It was also during Mo's time in Suluk that IS leader Abu Bakr al-Baghdadi announced the establishment of the 
Caliphate, and he recalls the celebrations among the IS members. One thing that disturbed him was IS members cheering and calling themselves irhabeen (Arabic for "terrorists") a term often used by jihadists to describe themselves and celebrate their acts of violence. This, he claims, was further confirmation that he had grossly misunderstood the group he joined.

Among the most valuable pieces of information provided by Mo in the interview was his explanation of how new recruits were processed and trained. After waiting in Suluk for two weeks, he and dozens of others were taken to a camp named Farooq, which he described as a "sharia camp" focused on ideological indoctrination. Home to around 300 recruits, it was under the control of a senior IS member with the title of Emir of Sharia and Teaching, whom Mo only knew by his first name, "Amari." The camp's exact location was unclear to him, other than it was south of Raqqa, in north-central Syria. The area between Suluk and Raqqa spans about 50 miles, and during the time Mo was there, it was either under direct IS control or contained corridors through which the group could safely pass. Upon arrival, recruits were separated by native language and put through various forms of sharia training, including classes on creed (aqidah), methodology (manhaj), Quranic study, and some basic tactical training. "They were basically teaching us Wahhabi stuff," he said, referring to the form of conservative Islam taught in Saudi Arabia.

During his time in Camp Farooq, Mo again found himself again being questioned by more ideologically committed Americans. When an IS commander asked his group who among them wanted to go and fight in Deir ez-Zor, a town to the southeast of where they were, Mo recalls how he hesitated to volunteer: "I sort of half-raised my hand but then quickly put it back down." He was now desperate to avoid a fight, but some of his fellow Americans took notice, including "this one guy from Harlem [who] saw what I did and criticized me in front of everyone."

Mo soon let his mask slip again during a class at the camp, when he expressed doubts about his commitment to his teacher. "I told him I was experiencing waswas," an
Arabic term used in Islam to refer to the evil whispers of shaytan (the Devil) which sow doubt in one's mind. He immediately regretted this action, however: "After expressing doubts about Deir ez-Zor, I was stupid to put attention on myself again." He was right to worry. Later that day a sheikh at the camp warned his pupils to "watch out for those who make doubt, they have question marks on their heads." This terrified Mo, who saw the remark as a direct threat to his life.

After three weeks in Camp Farooq, they were moved to Camp Abdullah Azzam (known colloquially as Camp AA). Here, the focus was much more on military training, and the facility's previous use as a Syrian army camp made it fit for purpose. During drills, recruits who were identified as the toughest and most able to fight were transferred to what Mo said was called "commando training," something he was not cut out for, neither mentally nor physically.

At each camp Mo attended, he was required to fill in a Microsoft Access form with details of his age, experience, and what he felt he could offer IS. The electronic form for Camp AA also asked what role he wanted to take on. He was offered the choice of a being a fighter, a suicide bomber, or an inghimasi, which refers to someone who fights on the front line while wearing a suicide vest.

According to Mo, none of these options were appealing. Instead, he tried to offer his services as a "researcher" to avoid fighting: "I didn't want to fight, so I told them I went to a very good school, and my value to them was my mind." In a desperate bid to sway his commanders, he pitched an idea involving the construction of a device that could emit an electro-magnetic pulse (EMP), which he claimed could help them down enemy fighter jets. It was a truly last-ditch effort and, as he admitted, "I didn't know [expletive] about making an EMP, but I figured this could buy me some time."

To his relief, Mo was not pressed any further about his EMP idea. His scheme to avoid the battlefield worked. His commanders decided to send him to Manbij in northwestern Syria to work with an IS emir who was handling the group's local transport logistics and designing 
bunkers and underground tunnels. Interestingly, Mo claims that IS was using Palestinians who had become experts in tunnel building for Hamas to dig routes for IS between Syria and Turkey. Unable to read or write Arabic, though, he was only of limited use and was eventually tasked with teaching less tech-savvy members how to use various computer programs.

By this time, however, Mo committed to leaving IS territory and the group. Since his time in Camp AA and in Manbij, he was trying to devise a plan for how he could escape. Through some online research at an internet café, he learned that people were leaving Syria for Turkey via several border crossings. Reaching Turkey seemed a realistic prospect, but he was going to need some help, and a lot of luck.

First, Mo needed a viable excuse to be allowed to leave. He decided to exploit the traditional instincts of his commander by telling him that he had met a girl online whom he wanted to marry but needed to visit first. After getting permission to leave, he took a minibus to Raqqa, followed by a taxi to Tal Abyad on Syria's northern border with Turkey. He hoped to cross the border there, but as he approached, he noticed IS members guarding the checkpoint. He could not risk being recognized and was forced to turn back, taking a taxi to Manbij where his commander was waiting for him. The disappointment, however, was etched on his face and, recognizing the situation his passenger was in, Mo's driver took pity on him. As with many taxi drivers in the area, he was also a smuggler. He told Mo he could help him cross into Turkey, but he was going to have to wait a few days.

In the meantime, he had to explain to his commander why he was returning without his new wife in tow. Although his excuse was that she had refused his proposal, "they didn't believe me and got suspicious." He began noticing that he was treated differently, and "people got cold towards me very quickly."

The shift increased his paranoia about being executed by a group whose leadership had already demonstrated a "better safe than sorry" approach towards Western members with questionable loyalties. On top of this, Mo had also noticed that a higher percentage of the
English-speaking members he knew were being sent to the front lines and dying in battle.

Realizing that his escape was now or never, Mo began to take more significant risks. On October 31, 2014, just five months after traveling to join IS, Mo bought a SIM card which allowed him to send emails-something he claimed was against the rules-and sent a message to the FBI. Having already been interviewed by FBI agents while in America, he hoped they would be able to verify his identity and pick him up once he crossed the border. "Please help," he wrote, claiming that "my window is closing," and "I'm fed up with this evil." Rather fancifully, he also asked for "complete exoneration" and to "have everything back to normal with me and my family." The FBI's response was only mildly reassuring. Mo was told that U.S. authorities could do nothing to help him while he was still in Syria and that he would first have to make his way to a U.S. consulate in Turkey.

I'm an American who's trying to get back home from Syria. The FBI has a file on me and I can verify who I am with random information you ask me.... I've coordinated a way to get to the border ... in Turkey and near . . . Syria . . . by use of civilian smugglers. My problem is that I need a pickup from trusted sources because I'm without passport. It was taken, and they won't give it back.... If someone can pick me up safely from across the border before [Kurdish forces] get to me, then I'll be $100 \%$ in the right hands. ... Please help. I had a week [sic] thought out letter, but it's too risky to have it saved on my device. I'll try to write to you soon in full explanation. But right now my window is closing.

I just want to get back

home. All I want is this extraction, complete exoneration thereafter, and have everything back to normal with me and my family.... Please help me get home. ... I'm fed up with this evil. But please first coordinate our extraction as soon as possible.

Redacted version of Mo's message to the FBI, October 2014.

Mo's only hope was the smuggler from Raqqa who had taken pity on him, but he would still have to escape the IS headquarters on the outskirts of Manbij. On the day Mo had agreed to meet him in Raqqa, he had another stroke of luck. Fighting around the area had been particularly intense, and guards were not manning the gates of the camp: "I just walked out of the front gate and got a ride into town." After leaving the camp, he went to Raqqa and met the smuggler. Once Mo reached Raqqa, he was taken 
to the border crossing where, for the final leg of his journey, he was guided into Turkey on foot by a young boy.

On November 4, four days after he had contacted the FBI, Mo arrived at a U.S. Consulate in Turkey and announced himself. During his discussions with U.S. officials, he recounted his experiences over the last five months with IS. He also willingly provided all the intelligence he could offer, including smuggling routes, locations of the IS camps he had visited, and the names of the Western members of the group whom he had encountered.

Mo was eventually sent back to the U.S. and charged with providing material support to a foreign terrorist organization and receiving military training from a foreign terrorist organization. He pled guilty to both charges in late November 2014. Today, he continues to fully cooperate with investigators. ${ }^{19}$

Most aspects of Mo's story, including his claims to have not actually "fought" for IS, have been corroborated by U.S. authorities. Of these assertions, the most naturally questionable statement is that he was unaware of how violent IS was. Unsurprisingly, it is a claim made by numerous Americans and other Westerners who traveled to Syria or Iraq before returning home or being captured on the battlefield by Western forces or their allies. Of course, these claims can be dismissed as attempts to avoid the harsh penalties that come with terrorism convictions. However, this also highlights how many Westerners who are legally treated as "foreign fighters" after traveling to join IS and other jihadist groups may never have seen any actual combat.

Mo's expressed desire to "live under Islam" is shared by many others who travel to IS territory. The utopian and religious appeal of this message must not be ignored. Not all members are violent psychopaths out for a cheap thrill; some are committed to IS' religio-political ideal and see it as the most effective vehicle for the Islamist vision (and, of course, some members likely fit both categories).

Mo now appears to have rejected the zealous idealism that drove him to leave his home in the first place: "All the [expletive] I've been through, I don't care anymore. America is my home." His view of the U.S. has also been influenced by his treatment from U.S. authorities since his surrender. Prosecutors have given him significant leeway and assistance in return for his cooperation. Some may believe, in fact, that the U.S. judicial system's treatment of Mo has been too lenient. In any event, his experiences after returning to his native country have led him to question his previously held notions of America's supposed war on Muslims.

In the future, Mo may also be useful to those hoping to sway radicalized Americans seeking to join or act on behalf of the group. Having been part of IS, he will have the credibility that few others do. His message to them is simple: "Don't be impulsive, think and sit still before you do something stupid."

\section{Mohamad Jamal Khweis}

On February 3, 2017, just days after taking part in the military operation that removed IS from Mosul, Colonel Arkan of the Kurdish Peshmerga forces was sifting through a haul of documents on the first floor of a house IS had converted into an office building. As he looked through each sheet of paper, one piece of information caught his eye. It was a document containing details of an IS recruit named Abu Omar al-Amriki. Having worked alongside the U.S. military on various counter-terrorism operations, the Colonel had a keen eye for information that American intelligence would find useful, and any IS member bearing a kunya that ended in al-Amriki certainly fit the bill. Taking a closer look at the spreadsheet detailing the recruit's personal information, he also found the fighter's real name: Mohamad Jamal Amin Khweis. ${ }^{20}$ Under the category of "current mission" was written Muqatil, Arabic for "fighter." ${ }^{11}$

Nearly a year before this find, which would serve as a critical piece of evidence in Khweis' trial, Peshmerga forces in Northern Iraq arrested a young American who, it was later revealed, was Khweis. ${ }^{22}$ He had fled IS some days earlier and handed himself in to Kurdish forces. After spending over two months in Kurdish custody and being interrogated by the FBI, he was extradited to the U.S. to face charges of fighting for a designated foreign terrorist organization. ${ }^{23}$ 


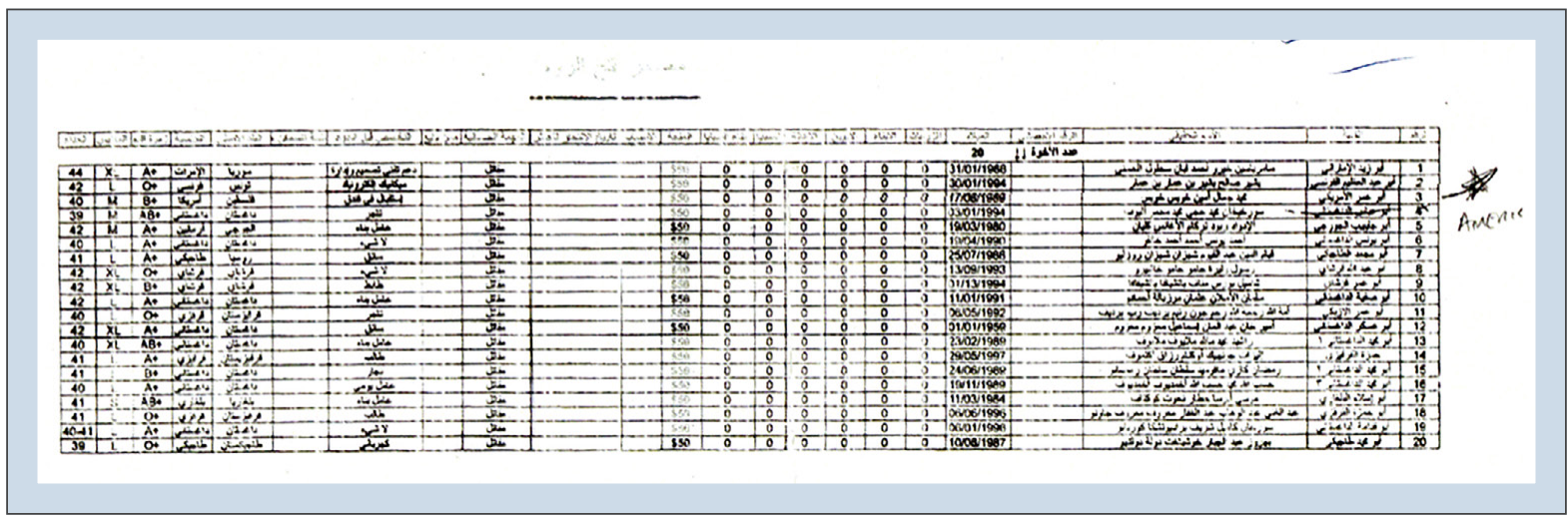

Mohamad Khweis' intake form from IS-controlled Fatah al-Rum training camp, with Colonel Arkan's inscriptions.

The case of Mohamad Khweis, a former Metro Access driver from Virginia who traveled to join IS in late 2015, is emblematic of the loner category of American travelers. His story shares several similarities to Mo's. He reportedly told no one of his plans before he left, was largely influenced by his online activities, was not involved in any known physical jihadist networks in the U.S. and even took a similar route into Syria.

However, his case differs in two crucial ways. Firstly, he traveled a year and a half after Mo and was operating in a much less permissible environment. Authorities had by now begun to allocate more resources to investigating cases of Americans joining IS. This meant that, unlike Mo, Khweis had to take extraordinary measures to mask his communications and movements. As a result, this case reveals much more about how Americans were able to use the latest encryption and location masking technology to join IS. Of all the instances of American travelers, none have yet provided as much information about what technology they use to communicate and cross the border between Turkey and Syria. ${ }^{24}$ Through his use of a suite of online tools, Khweis was able to plot his route into IS territory apparently without any outside assistance until reaching the Turkish border with Syria.

In addition, Khweis pleaded not guilty to the charges he faced and against the recommendations of his defense team, he also took the stand at his trial. ${ }^{25}$ The cross-examination of Khweis as a witness during his trial allowed for the revelation of details that offer rare and useful insight to researchers.

\section{Motivations}

Unlike Mo, who had expressed a desire to live a more devout Muslim life after adopting a stronger Muslim identity, there is little evidence that Khweis experienced any semblance of a religious awakening. During his trial, he claimed that he was not devout, rarely prayed, and had even been drinking alcohol while making his way to IS territory. ${ }^{26}$

Among other revelations from this trial were the details of a series of interviews Khweis gave to the FBI while still in Kurdish custody in Erbil, Iraq. During these discussions, Khweis explained both why and how he joined IS in Syria, including an admission that he had agreed to become a suicide bomber for the group. Unlike Mo, who joined during the earliest phases of the group's ascendency before it was widely publicizing its violent acts Khweis admits to being fully aware of the nature of IS. He watched the group's extreme propaganda, including the video depicting the immolation of Jordanian pilot Muath al-Kasasbeh. ${ }^{27} \mathrm{He}$ also viewed numerous sermons from well-known English-language jihadist preachers, including Abdullah al-Faisal, Anwar al-Awlaki and Ahmad Musa Jibril. ${ }^{28}$

According to one of the agents who conducted these early interviews, Khweis' inspiration to join IS was driven by his desire to be part of the establishment of the Caliphate. This was despite being aware of IS involvement in overseas terrorism, including the November 2015 Paris attacks, which took place just a month before Khweis left to join the group. 
While the evidence strongly suggests that Khweis was sympathetic to IS, and he was found in possession of phones containing numerous pieces of the group's propaganda, he also later claimed during his trial that he believed aspects of IS' ideology went against Islam. These perspectives represented a significant part of his defense, in which he argued that he disagreed with IS' use of violence, had joined the group out of curiosity, and was forced to agree to become a suicide bomber out of fear for his life rather than due to his deep commitment to the organization. ${ }^{29}$

Further contributing to the lack of clarity surrounding Khweis' motivations was his evasiveness during discussions with the FBI. The agents noted in the trial that he changed his story on a number of occasions. For example, on the subject of his agreeing to be a suicide bomber, he first claimed he did so to prove his commitment to the group and only later made the claim that he agreed out of fear. He also initially claimed to the FBI that he had "given" himself to the group. ${ }^{30}$ It "controlled" him and he would have acted on orders he received from superiors whether or not he agreed with them. ${ }^{31}$ Later on during his trial, however, Khweis testified that he traveled to IS territory to satisfy his curiosity about a group he had been researching for many months. During cross-examination, he claimed that:

I wanted to go to the Islamic State, the caliphate, and see for myself how it is, how are people living there, and one day tell my kids, I have been there. You know, it's not all like it seems ... I just wanted to, you know, just share with them like history, like places, places I have been. ${ }^{32}$

Considering that Khweis had mounted a vigorous defense after his "not guilty" plea, it is difficult to determine why he joined IS. His assertions denying his support for the group during the trial must be seen in this context, while also not being dismissed out of hand. Among the claims that were not disputed by the prosecution was that he was not profoundly ideological and had no links to a wider jihadist network. However, there is irrefutable evidence that he was in possession of a wide array of IS propaganda, had traveled to IS territory in the full knowledge of its role as an international terror group that was targeting the U.S., and had willingly gone through the official IS intake process for all new recruits. Like many similar stories of IS recruitment, there may never be a fully comprehensive account of what drove Khweis to join the group.

\section{Journey}

In many ways, Khweis' journey to IS territory mirrors that of many other American travelers. He took a similar route, crossing the border near the Turkish town of Gaziantep on his way to Raqqa and a number of other IS strongholds in Syria and Iraq. The authors have since uncovered details about his case which allow for the most in-depth understanding about how American IS travelers make their journeys.

After approximately a year of planning, one of the first steps taken by Khweis once he had resolved to make the trip was to sell his car to help both pay off his credit card debts and finance his travel. ${ }^{33}$ While it may seem a strange priority, these credit card payments were likely a diversion to distract investigators from his plans, by suggesting that he intended to return to America and continue his life. According to the FBI, this is a common tactic among successful and unsuccessful IS travelers. ${ }^{34}$ He also created the first of several new email addresses that he would use during his journey. Within minutes of setting this account up, he used it to book his flights from the U.S. to Turkey. ${ }^{35}$

On December 16, 2015, Khweis, equipped with five cellular phones and a laptop, took the Iceland-based budget transatlantic airline WOW Air from BaltimoreWashington International Airport, via Iceland, to London Gatwick. ${ }^{36}$ While at the airport in London, he attempted to contact a well-known British extremist and member of the al-Muhajiroun network named Abu Bara'a, but he did not receive a response. ${ }^{37}$ From Gatwick, he flew to Amsterdam, where he spent two days staying in the city's red light district. His final flight was from Amsterdam to Istanbul. ${ }^{38}$

While still in America, Khweis also purchased a separate ticket for a flight from Istanbul to Greece which, like 
Mo's ticket to Italy, he never intended to use. ${ }^{39}$ Instead, he hoped it would mask his final destination from any suspicious border or law enforcement agencies. This also explains the circuitous route he took through Europe on his way to Turkey, which also helped him avoid any undue attention from authorities. While in Turkey, he booked a flight back to Washington, D.C., which he never boarded. This step was yet another effort to conceal his intentions and give the impression that he planned to return home after an innocent trip. ${ }^{40}$

Upon his arrival in Istanbul on December 20, Khweis took a bus to Gaziantep. ${ }^{41}$ While in the border town, Khweis created another email address using the name Zach K. ${ }^{42}$ and set up two Facebook accounts and a Twitter profile using the handle @fearislove1, which he intended to use to contact IS members who could facilitate his travel into Syria. ${ }^{43}$ One of his two Facebook accounts was set up using a nonexistent email address, again a standard tactic for IS travelers attempting to mask their identity.

Khweis' new email address was also used to set up an Apple ID which he used to download a variety of secure messaging applications he hoped would help him speak with IS members and mask his location and online activity. Between the time of his arrival in Turkey and his crossing of the border into Syria, he downloaded a host of apps that were based on encrypted communication and masking online activity including Kik, Surespot, Telegram, VPN Master, VPN Defender, VPN InTouch, and a Tor browser called VPN Browser. ${ }^{44}$ Following his passage into IS-controlled territory, he continued expanding his digital toolbox. Among the apps he downloaded in Syria were secure/encrypted calling applications, including Vodafone Secure Call, VIVA Secured Call, Cryptotel, and Secure Video Calls Free. ${ }^{45} \mathrm{He}$ also used an app called Snaptube to download IS videos from YouTube, including videos of executions and mass graves. ${ }^{46}$

After four days of trying to contact IS members using his new Twitter account, he gained little traction and decided to create a second account with a name that was more explicit in its support for the group: the username "Greenbird" with the handle @iAGreenBirdiA. ${ }^{47}$ As
Khweis would later admit to FBI interrogators and in court, the names were an open advertisement to online IS recruiters of his sympathy for the group and his desire to die fighting for it. "IA" is an acronym for the Arabic term inshallah, meaning god willing, while "GreenBird” refers to the belief that people who die fighting for IS are martyred and turn into green birds for their ascent to heaven. One of the agents who interrogated Khweis testified in court that he "acknowledged that [IS] and other violent terrorist groups use this to reference martyrdom, violent jihad, suicide bombing." ${ }^{48}$

Using his new Twitter account, he reached out to at least three different Twitter users whom he had identified as actively assisting people who wanted to travel into Syria and join IS. The first responded to his request for help by telling him "I am a sister," suggesting that she was only able to interact with and help other women. ${ }^{49}$

An account named “Mad Mullah” (@martenyiii) eventually helped Khweis. ${ }^{50}$ The account's biography info stated that the user was based in Syria and offered advice on hijrah and other matters related to IS. Subsequent investigations by the authors have found that this account was involved in helping at least one other person travel to join the group. ${ }^{51}$ This account also interacted on Twitter with Shawn Parson (Abu Khalid al-Amriki), a Trinidadian national who fought for IS and appeared in one of the group's recruitment videos targeted at other Trinidadians. ${ }^{52}$

On December 25, Khweis had sent a direct message to Mad Mullah: "Salaam akhi [brother] do $\mathrm{u}$ have Telegram?"53 He was then asked to move their conversation to the encrypted messaging application. On this app, Khweis was told to download a second similar encrypted messaging application to which they moved and had a detailed conversation about arranging Khweis' safe passage into Syria. ${ }^{54}$ This three-tiered communication approach-from Twitter, to Telegram, and finally to a third encrypted messenger application-demonstrates the length that IS members were going to hide their tracks online, making it very difficult for authorities to track their activities in real-time. 
This example mirrors the tradecraft of IS travelers attempting to avoid detection online as they plan their route to the Caliphate and reach out to IS recruiters and facilitators. This approach appears to have worked in Khweis' case. Based on the information currently available, Khweis' interest in IS and his trip to join the group was completely unknown to authorities until his arrest by Kurdish forces in March 2016. Khweis' journey was only uncovered after his arrest, when he informed the FBI of his online activity and usernames. Despite volunteering this information, authorities do not appear to have been able to access the encrypted discussions Khweis had on Telegram and other similar applications.

Khweis was staying in his hotel room in Gaziantep when he contacted Mad Mullah. Later that day, he received a call telling him to meet with IS smugglers outside the hotel. Khweis left Gaziantep in a taxi, continued on foot across the border, and then traveled into IS-held territory in an SUV. ${ }^{55} \mathrm{He}$ was joined by other
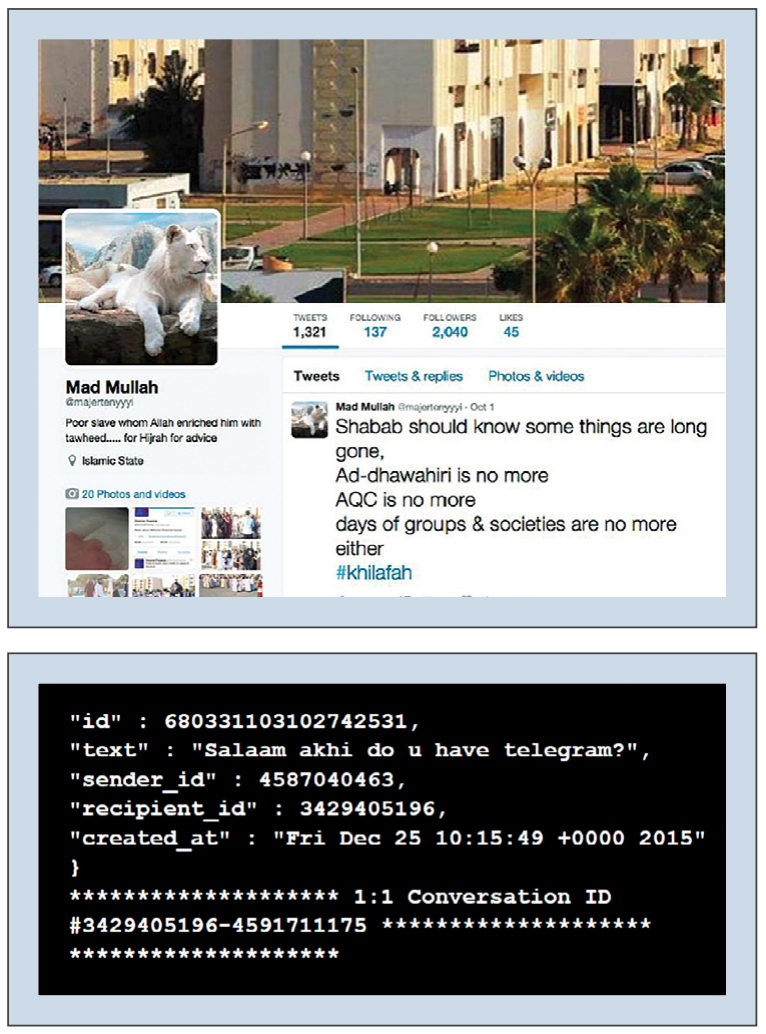

Top: Twitter account of "Mad Mullah." Bottom: Private message from Khweis' account to Mad Mullah, December 2015. new recruits, including, according to his own account, three men from Paris who claimed to have been inspired by the recent attacks in the city. ${ }^{56}$ During the journey they were instructed to put their phones on airplane mode and, if possible, remove the batteries to avoid possible detection. ${ }^{57}$ Similar to Mo's account, they too were stopped by Turkish police near the border, but were released after negotiations between the police and the taxi driver. ${ }^{58}$

\section{Khweis in Syria}

Over the next few weeks, IS members took Khweis to a series of safe houses where he received ideological training and interacted with other travelers from around the world. He recalled to interrogators an unusually high number of Russian speakers from former Soviet countries. ${ }^{59}$ Khweis' first experiences in Syria and Iraq were navigating the labyrinth of administrative bureaucracy that IS had created in its held territory.

In the first of these safe houses, located in Raqqa, he underwent the basic IS intake process for newcomers. He handed over his passport and driver's license, and his details were entered on the Microsoft Access form that Colonel Arkan would later recover in Mosul. Taking the kunya "Abu Omar al-Amriki," this is when he expressed his willingness to become a suicide bomber. ${ }^{60}$

In the second safe house, also in Raqqa, Khweis spent two weeks undergoing religious training. During this period, he was introduced to the details of IS ideology. He studied alongside around 60 other recruits, including unnamed American and Australian citizens. ${ }^{61} \mathrm{He}$ also underwent a blood test intended to check him for various diseases. Though it is unknown if IS could properly test the sample, he was given the all clear and issued with an official IS medical identification card. ${ }^{62}$

Most significantly, however, it was also in this safe house where Khweis was introduced to the Jaish al-Khilafa brigade. Jaish al-Khilafa is a unit within IS tasked with identifying and training recruits from Western countries, with the intent of sending them back home to conduct terrorist attacks. ${ }^{63}$ Members of the unit explained to Khweis the requirements of joining, which included 
having to be single, uninjured, and willing to train in remote locations with minimal food and water. He was also told that when a recruit returns home, they would have to live a reclusive lifestyle to avoid detection. ${ }^{64}$ While Khweis declined to join them, he later told investigators that another American, who remains unnamed, left with the group before returning some days later with medical issues. ${ }^{65}$

Following this, he was sent to a third location on the outskirts of Raqqa to receive more detailed religious training, before being moved to yet another safe house. This facility was located in Mosul, Iraq, during the time the city was under IS control. Staying in an abandoned church with around 60 other IS members, for 25 days he underwent further religious training along with some basic medical training ${ }^{66}$ Here, he was instructed to help care for injured fighters and maintain the residence. While Khweis was promised that he would soon receive the military training he sought, this did not, according to his own account, materialize. ${ }^{67}$

His final destination before he deserted was an IS katiba (IS community) made up of fighters and their families in Tal Afar, Iraq, where IS issued Khweis a uniform and instructed him to carry out basic tasks. He stayed in the katiba for about 30 days. ${ }^{68}$ As part of the indoctrination process he was undergoing, Khweis claims to have watched videos of apparent atrocities carried out by the Iraqi army on IS members and civilians. ${ }^{69}$

In a number of cases, when inexperienced recruits such as Khweis first arrive, they act as apprentices to IS fighters who pass through the safe houses, cleaning up after them, arranging their meals, and organizing their weapons. For many, this inauspicious and unglamorous experience goes against the expectations they had developed before joining. In Tal Afar, Khweis grew tired of running errands and became frustrated that he was not receiving any military training. He expressed his concerns to a senior IS member in the area and, while he was promised things would change, they did not. This may have influenced his eventual decision to leave the group. ${ }^{70}$

Khweis' escape from IS mirrored Mo's. Having gained the trust of his IS overseers while in Tal Afar, he was afforded more freedom than before, including being allowed to leave the house unescorted. Like Mo, he claims to have befriended a local taxi driver who helped him plan his route to Kurdish-held territory in Iraq. Having read about the American military alliance with the Kurdish Regional Government and its Peshmerga forces, he correctly
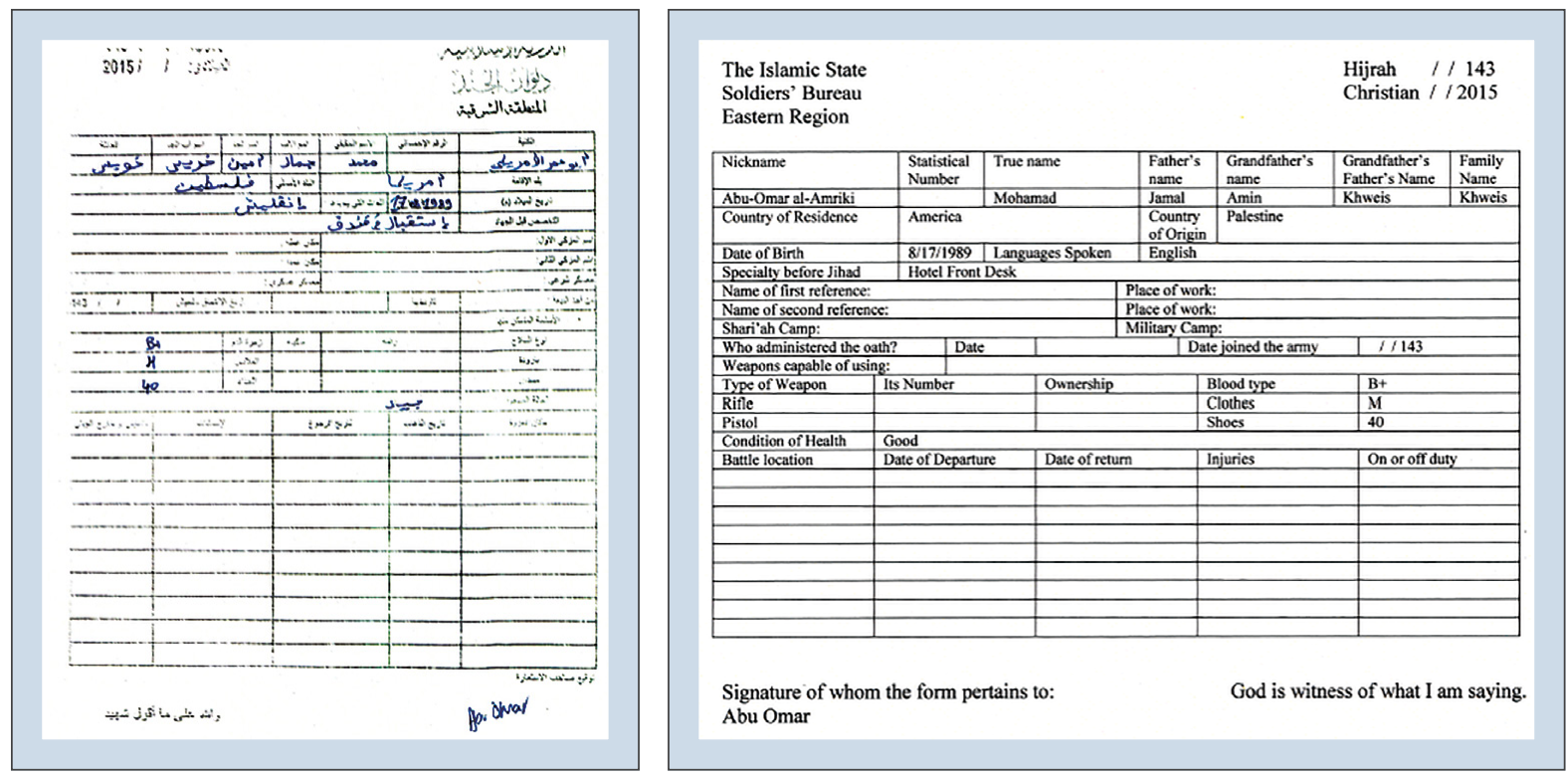

Left: Mohamad Khweis' IS Soldiers' Bureau, Eastern Region intake form in Arabic. Right: His form in English. 
assumed that they would be the most likely to help return him home to America. Aware that there were Kurdish forces near to Tal Afar, Khweis downloaded a number of maps that helped him eventually find the Kurdish controlled region of Northern Iraq. ${ }^{71}$

After several preliminary attempts, Khweis left Tal Afar for Kurdish-held territory. Prior to doing so, he destroyed his laptop and cell phones. Khweis' taxi driver contact, fearful of retribution, refused to drive Khweis all the way into Kurdish territory.

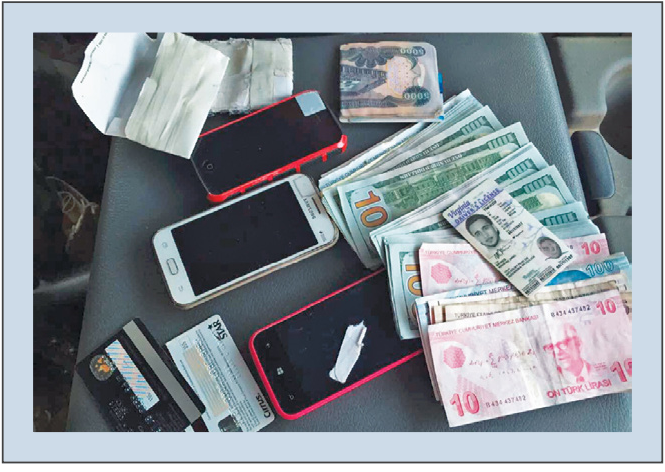

Personal property recovered from Mohamad Khweis at the time of his arrest by the Peshmerga, including two credit cards, U.S. dollars, Turkish lira, Iraqi dinar, three cell phones, and a Virginia drivers license. out to facilitators upon arrival near the Turkish border with Syria. While this may appear to be a remarkable feat given the length of the journey and security challenges involved, groups such as IS and its sympathizers online have made extensive efforts to provide "travel guides" for Westerners intent on joining them. ${ }^{77}$ These guides detail the latest and most secure communication applications, the most reliable facilitators, and the most secure routes. In the cases of the two individuals profiled in this section, their use of the internet, along with variety of operational security measures, ensured that both succeeded in traveling to join IS.

Thus, the role of online communications is also perhaps the most prevalent among cases in this category. Several recent developments in technology (particularly regarding secure and encrypted messaging) have proven to be valuable tools for modern insurgent and terrorist groups. In lieu of access to physical networks, both Mo and Khweis utilized virtual networks to facilitate their travel. Both men "met" the individual that was able to assist them in traversing the Turkish-Syrian border via Twitter. Highlighting the changing nature of IS' use of digital communications technology, Khweis, who traveled more than a year after Mo, was directed to several other messaging and communications platforms after first making contact on Twitter.

The track record of American recruits using social media as a "stand-in" for in-person travel facilitation networks is generally poor. There are dozens of cases in which a would-be traveler to Syria and Iraq who reached out to others on Twitter or other platforms caught the attention of authorities. ${ }^{78}$ Mo avoided detection by waiting until arrival in Turkey to reach out to a facilitator on Twitter; Khweis covered his tracks with a host of encrypted 
messaging applications, anonymous browsers, multiple access devices, and other cybersecurity procedures.

Finally, these two "loners" demonstrate the multivalent impact of IS' recruiting strategy towards Westerners, particularly Americans. Due to their fear of legal retribution, both Mo and Khweis' accounts should be taken with a grain of salt. However, they cited not only the graphic, hyper-violent videos that many associate with IS, but also the group's other propaganda output, depicting the legitimacy of their system of governance and their enforcement of Islamic law. It is essential to consider the differential impact of both types of messaging, and how they may contribute to drawing different types of recruits. ${ }^{79}$
The stories of Mo and Khweis provide several new and unique insights into the motivations of American travelers and the methods they used to travel to join IS. While likely not generalizable, they demonstrate that in the U.S. context even individuals without access to broader facilitation networks still manage to go overseas to support jihadist groups. Neither Mo nor Khweis, according to publicly available evidence, were connected to any physical recruitment network or other cases of travel or support in the U.S. While not representative of the broader sample-most American travelers did so in conjunction with others-the loners reveal that faceto-face access to recruiters is not necessary to radicalize or successfully travel. 



\section{Returning American Travelers}

$\mathrm{B}$ ased on the original research presented in this study, 12 Americans who traveled to Syria and Iraq to join jihadist groups have since returned to the U.S. ${ }^{1}$ This count may not include all cases, but if the actual numbers of returnees generally mirror this estimate, the U.S. has faced a much smaller inflow of returning travelers than other Western countries. In Europe, for example, it was estimated in October 2017 that around 1,200 of the 5,000 citizens of the European Union (EU) who left for Syria and Iraq have returned to their home countries. ${ }^{2}$

As IS faces territorial decline, the concern for Western law enforcement officials is twofold. First, travelers could return to their home countries and re-integrate into the domestic jihadist milieus that they left behind. They may also participate in attacks. What is less clear, however, is the precise numbers, roles, impacts, and overall threat of returning travelers. Different countries-with varying traveler contingents, unique domestic national security situations and perspectives, and diverging political climates regarding how the state should respond-face different threats from returnees.

Geographic, economic, and legal barriers, in addition to a substantially smaller traveler contingent, decrease the risk that an American traveler will return to the U.S. and conduct an attack. However, this assessment of 12 known cases of American returnees, situated in a broader review of 22 jihadist attacks in the U.S. since 2011, finds that:

- None of these 12 American travelers who returned to the U.S. from Syria and Iraq since 2011 successfully carried out a domestic attack. None of the 22 jihadist attacks in the U.S. since 2011 were carried out by returned travelers. ${ }^{3}$

- One individual-Abdirahman Sheik Mohamud-who returned to the U.S. from fighting in Syria and Iraq was directly instructed by his group's leadership to carry out an attack in the U.S. However, he was apprehended in the early planning stages of the attack after re-entry.

- Overall, U.S. law enforcement and the U.S. criminal justice system have effectively monitored, detected, and where applicable, prosecuted returning travelers.

- The approach to returnees has mostly been ad hoc rather than strategically organized, and over-relies on criminal prosecution, convictions, and lengthy prison sentences. Due to the complexity of cases of returnees, these options may not always be available. Moving forward, alternative mechanisms for responding to the threat of returned jihadist travelers are necessary to supplant the existing criminal justice process.

\section{Recruitment, Returnees, Reintegration: Challenges Facing the U.S. Regarding Jihadist Travelers}

Returning Western travelers are regarded as threats to their countries of origin because of the risk that they may re-join and participate in jihadist networks at home. However, in the case of the U.S. and the broader Western context, the major questions for national security authorities are not only if returnees will participate in jihadist movements, but how they will do so. ${ }^{4}$

These concerns were validated by the November 2015 Paris attacks and 2016 Brussels bombings, orchestrated by IS-affiliated jihadists who returned from Syria to conduct their attacks. Studies of earlier mobilizations have found that experienced jihadists returning from abroad increase the lethality of domestic terrorist plots. ${ }^{5}$ However, these studies often assume the existence of large-scale domestic jihadist networks or organized militant Salafist groups in travelers' countries of origin, which returnees can become involved in upon re-entry. Thus, these findings may not equally apply to the U.S., which lacks these factors. ${ }^{6}$

Nevertheless, there are several mitigating factors to large-scale re-entry of jihadist operatives into their 
countries of origin. Most will die on the battlefieldalready, European and American intelligence officials have estimated that at least half of the traveler contingent in Syria and Iraq has been killed. ${ }^{7}$ From the remainder, a significant number will either be apprehended by competing factions on the battlefield, or arrested while trying to return home. Some will migrate onwards to the next major conflict. ${ }^{8}$

Despite these limiting factors, travelers can and will return home; many already have. Even in the early days of the conflict, between January 2012 and July 2014, 300-400 travelers reportedly returned to Europe from Syria and Iraq. ${ }^{9}$ A subsequent study in 2016 averaged statistics from EU member states and estimated that around $30 \%$ of the 4,300 travelers from these countries had returned. ${ }^{10}$ This is not to suggest, however, that all returnees pose immediate security threats or should be dealt with in the same manner. The critical issue remains which of these returnees intend to stay engaged with their jihadist organizations by recruiting, networking, and even planning attacks after their return, and which are going home after completely rejecting their former organizations.

Across the ocean, the U.S. government has repeatedly expressed concerns about the risk of American returnees attempting to conduct attacks on U.S. soil. In 2014, then-FBI director James Comey testified that:
U.S. intelligence officials demonstrate that the perceptions of the threat from returnees have been updated to account for changing realities. Former National Counterterrorism Center Director Nicholas Rasmussen claimed in May 2017 that while counterterrorism authorities in the U.S. were "worried about being overwhelmed by this reverse foreign fighter flow ... we have come to realize it is quality that matters, as much or more than quantity, when it comes to foreign fighters returning home."12

With these concerns in mind it is important to point out that the story of IS mobilization in America is characterized by a desire among adherents to join the group overseas, rather than conduct terrorist attacks on its behalf at home. As of January 1, 2017, 42\% of IS-related legal cases included an attempted traveler, whereas only $32 \%$ involved individuals who were plotting domestic attacks. A simple cost-benefit analysis for IS supporters would seem to point towards a higher number of domestic attacks. In the age of lone-actor terrorism, it is arguably more straightforward for an American IS sympathizer to plan and conduct a low-level terror attack than it is for them to successfully travel to IS territory. The risk they run of being killed or apprehended on the battlefield is at least as high as it is while planning or conducting an attack at home. Yet, a greater number of American IS supporters attempted to travel to Syria and Iraq rather than
Foreign fighters ... gain battlefield experience and increased exposure to violent extremist elements that may lead to further radicalization to violence; they may use these skills and exposure to radical ideology to return to their countries of origin, including the U.S., to conduct attacks on the homeland. ${ }^{11}$

The ongoing demise of IS in Syria and Iraq was predicted to result in an exodus of former travelers, including some Americans. However, recent assessments from plotting domestic attacks, even as the military fortune of the organization declined.

Nevertheless, as travel becomes an even more difficult prospect, there may be an increase in attack plots among those who would have initially preferred to travel. One relevant example is the case of Emanuel Lutchman, a 26-year-old resident of Rochester, New York, who intended to travel to Syria to join IS in 2015. When Lutchman reached out via social media to Abu Isa al-Amriki, an IS member and attack planner in Syria, he was told to 
forego travel and conduct an attack in the U.S. instead. ${ }^{13}$ Lutchman planned a stabbing rampage in Rochester scheduled for New Year's Eve 2015. ${ }^{14}$ Law enforcement apprehended Lutchman the day before the attack; he was sentenced to 20 years in prison in early $2017 .^{15}$

If American supporters of jihadist groups do shift towards primarily plotting domestic attacks in the coming years, how would a potential influx of returning travelers to the U.S. effect these dynamics? Contrary to initial concerns, the emerging consensus in the academic literature is that Western returnees are less involved in domestic terrorism than is often assumed. According to Petter Nesser et al., 45\% of IS-linked plots in Europe between 2014-2016 "involved one or more cell members with foreign fighter experience. ${ }^{16}$ While this figure appears high, they also note it represents a drastic reduction from previous mobilizations. Similar longitudinal studies in the U.S. find even fewer cases of returnees involved in jihadist plots. ${ }^{17}$

Related research by Thomas Hegghammer and Nesser also demonstrates that returnee involvement in domestic terrorism is rare, especially compared to the overall numbers of Western travelers. Their 2015 study, which examined 69 jihadist terrorist plots in the West (Europe, North America, and Australia) between January 2011 and June 2015, found a meager "blowback rate" of travelers involved in terrorist plots and attacks in their countries of origin. ${ }^{18}$ More specifically, they found that nine separate plots involved 11 individuals who had been to Syria, eight of whom received training from IS, and the remainder from JN or other jihadist groups. ${ }^{19}$ At the time of their research, the estimate was that there were approximately 4,000 travelers from the countries examined in the study. Thus, only one out of every 360 travelers returned to their home countries to plot attacks. ${ }^{20}$ Hegghammer and Nesser also note that IS sympathizers in the West who have not traveled to Syria or Iraq "outnumber returning foreign fighters as plot instigators." ${ }^{21}$

Despite this, in the rare instances where returnees have conducted attacks in Europe during the past five years, these attacks have been among the most lethal. ${ }^{22}$ From the Paris and Brussels attacks in 2015 and 2016 respectively, to the Manchester arena bombing in 2017, many of the attacks with the highest casualty numbers and levels of sophistication have involved people who traveled to jihadist-held territory.

To date, the U.S. has not only experienced fewer attacks conducted by returning travelers than in Europe, but some studies find that the few attacks since 2001 involving returnees are in fact less lethal than the U.S. attacks perpetrated by "homegrown" jihadists. ${ }^{23}$ This latter category includes attackers who, while inspired by jihadist ideology, had not traveled to join or train with a jihadist military organization overseas. None of the three most lethal jihadist attacks in the U.S. since the start of the Syrian conflict in 2011-the Orlando nightclub shooting in June 2016, the shootings in San Bernardino, California, in December 2015, and the October 2017 truck ramming attack in New York City-involved an individual that traveled and returned from jihadist-held territory.

To date, none of the 12 known returned American travelers from the Syrian and Iraqi conflict has successfully committed an attack in the U.S. following their re-entry. Since the start of the Syrian conflict in 2011 until the end of 2017, only one is known to have plotted an attack following their return, acting on the specific orders from their jihadist organization in Syria. The following section examines this story and its potential lessons for American policymakers and law enforcement seeking to address the threat of returnees.

\section{Abdirahman Sheik Mohamud}

In June 2014, 23-year-old Ohio resident and naturalized U.S. citizen Abdirahman Sheik Mohamud returned to the U.S. from Syria, where he had been a member of JN. ${ }^{24} \mathrm{He}$ was not immediately arrested upon his return, and pressed forward with the plans to conduct an attack given to him during his time in Syria.

Mohamud was following in the footsteps of his older brother, Abdifatah Aden, who left Ohio to join JN in August 2013 and died in battle approximately ten months later. ${ }^{25}$ During Aden's time in Syria, he kept in regular contact with Mohamud via private online messages. In their conversations, Mohamud repeatedly expressed a 
desire to join his brother "as a Mujahid," and coordinated the funding and logistics to facilitate Mohamud's travel. ${ }^{26}$ The final step involved Mohamud applying for a U.S. passport so that he could begin his journey to Syria. ${ }^{27}$ Mohamud also told another individual that he intended to travel to Syria to fight, and expressed his desire to kill the soldiers of U.S. allies on the battlefield. ${ }^{28}$

In April 2014, Mohamud booked a plane ticket from Columbus to Athens, Greece, using Istanbul as a stop-over. He never boarded his connecting flight to Athens, and from the Istanbul airport traveled to the Turkish-Syrian border town of Reyhanl, following his brother's instructions. ${ }^{29}$ Using a network of JN facilitators whom his brother connected him with, Mohamud was smuggled into Syria in late April $2014 .^{30}$ While in the country, he was trained in building explosives, using firearms, and hand-to-hand combat, before being specially selected by a JN cleric to return home and conduct an attack in the U.S. ${ }^{31}$

Before he returned home, Mohamud appears to have already begun his attack planning, visiting the website for the Federal Bureau of Prisons and searching for details on the location of Aafia Siddiqui. ${ }^{32}$ Siddiqui was a former Boston resident and al-Qaeda operative who was sentenced to 86 years in prison in 2010 for the attempted murder of a U.S. military

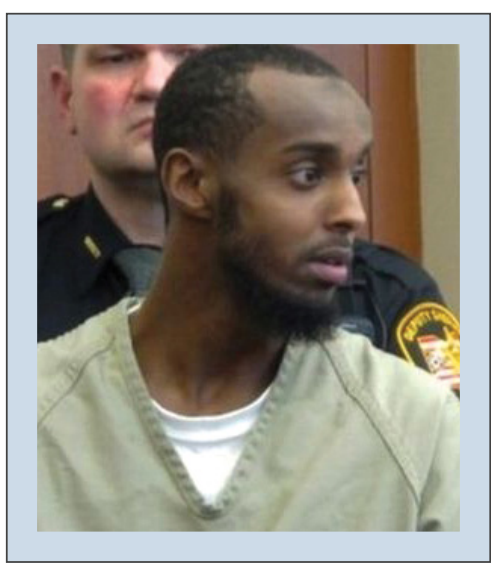

Abdirahman Sheik Mohamud or members of the armed forces to witnesses whom he had tried to recruit. ${ }^{36}$ He had also identified a military base in Texas where he hoped to be able to capture and execute American soldiers. ${ }^{37}$ In November 2014, he even booked a flight from his home in Ohio to Dallas/Fort Worth airport in Texas, but does not appear to have made the journey. ${ }^{38}$

At some point after returning to the U.S., Mohamud attracted the attention of the FBI. It is not clear how soon after his return from Syria that law enforcement made contact or started an investigation. According to court documents, agents first interviewed Mohamud about his travel overseas in February 2015. ${ }^{39}$ During this interview, Mohamud denied that he had any ties to jihadist groups in Syria, and told federal agents that he had never left Istanbul during his 2014 trip. $^{40}$

Mohamud was eventually arrested on February 21, 2015, on a rarely used Ohio state terrorism offense. He was pulled over by a police officer in Columbus for a routine traffic violation on the night of his arrest, and when asked to produce identification, he gave the officer his brother's driver's license. ${ }^{41}$ At that time, Abdifatah Aden was already on a terrorist watch list, and when the officer double-checked the driver's license, they arrested Mohamud on the spot. ${ }^{42}$

Eventually, a federal jury indicted Mohamud on two counts of providing material support to terrorists and one count of making false statements to the FBI in April $2015 .{ }^{43}$ In August 2015, Mohamud pleaded guilty to all charges. Mohamud was sentenced to 22 years in prison on January 22, 2018. ${ }^{44}$ Mohamud's case is the only currently known example of an American who, since the start of the Syrian conflict, returned home after receiving express instructions and training to carry out an attack from a jihadist group based in the region.

At present, the returnee threat to the U.S. is therefore negligible compared to that faced by most other Western 
nations. Unlike their European counterparts, which in some cases have been able to take advantage of open borders in the EU and exploit refugee flows into the continent to move more freely, American travelers have so far found it more difficult to return home undetected. There is currently no publicly available evidence to suggest that American travelers have slipped into the country without the knowledge of authorities. Any who attempt to do so also face among the most daunting obstacles of any contingent of Western travelers wishing to return home.

The current returnee threat picture in the U.S. may change, however, especially given the likely increase in American travelers who will be fleeing Syria and Iraq as IS and other jihadist groups lose territory. Now, more than any other time since the start of the Syrian civil war, is when authorities will need to be most vigilant in their tracking and pursuit of America's returning travelers.

With this in mind, it is important to note that attack-planning is not the only role that returning, experienced jihadists can serve in domestic terrorist networks in the U.S. As previously highlighted, certain travelers (for example, Christopher Paul, Jason Pippin, and Ahmad Abousamra) who returned to the U.S. from jihadist campaigns in the 1990s and 2000s became crucially important in assisting small-scale networks of jihadists in the U.S. In some cases, they acted as jihadists-cum-consultants, providing others who were looking to travel overseas or conduct attacks at home with information, connections, and technical expertise.

There are several cases where returned travelers served as trans-generational links between jihadist mobilizations. Eventually, they may travel or assist others in traveling to another battlefield, or in some cases, lend their expertise to individuals looking to commit attacks in the U.S. If not addressed appropriately, returnees could facilitate a future generation of American travelers.

\section{Criminal Justice Approaches to Returning Travelers}

The U.S. responses to returning travelers from Syria and Iraq have largely been determined on a case-by-case basis. U.S. national security decision-makers must decide whether American jihadist travelers who are attempting to return home should be arrested and prosecuted. This decision is based on two factors: clear evidence of a crime and the traveler's risk to national security.

At the time of their return to the U.S., all 12 known returnees had some touchpoint with federal law enforcement. At the minimum, their activities in Syria and Iraq and attempted return were closely monitored or investigated. Some were arrested upon return to the U.S., and others were detained overseas and returned to the U.S. in custody. In total, nine out of the 12 (75\%) known American returnees have been prosecuted in U.S. criminal courts following their re-entry to the U.S. Despite some debate about the use of military tribunals to prosecute returning travelers as "enemy combatants," the Article III criminal court system has so far been an effective forum for prosecuting returning travelers from Syria and Iraq.

Five returnees were arrested after returning to the U.S.; four more were arrested in a foreign country and returned to the U.S. in custody. As it stands today, the U.S. and its law enforcement agencies have been successful at identifying travelers, detecting if and when they return to the U.S., and prosecuting them where applicable. Overall, a compelling argument can be made that the U.S. process, which focuses primarily on criminal justice proceedings against returning jihadist travelers, has effectively responded to the threat. This can mainly be attributed to the extensive and flexible legal framework, including the material support statute and other terrorist travel laws, that were in place well before the outbreak of the Syrian and Iraqi mobilizations.

In the three remaining cases, the FBI monitored or investigated a returning traveler, but eventually declined to press charges. Decisions to forego prosecution of a returnee are complex and opaque, but in these cases, certain individual factors seem to have influenced the decision strongly. Tania Georgelas left Syria with her children after leaving her husband in 2013. ${ }^{45}$ Haris Harcevic traveled with Abdullah Ramo Pazara to Syria, leaving the country two weeks after he arrived. In both 
cases, law enforcement ultimately did not arrest or charge these individuals with any crime. ${ }^{46}$

In one case, however, a Florida resident evaded prosecution after returning to the U.S. from Syria, and later traveled back to Syria and conducted a suicide bombing. Moner Abu Salha, a 22-year-old from Fort Pierce, Florida, briefly participated in a militant training camp in 2012 before returning home and staying in Florida for several months. ${ }^{47}$ According to U.S. counterterrorism officials, at the time of his return to the U.S., law enforcement agencies had some knowledge of his first visit to Syria, but had insufficient evidence to prove that he fought for a designated foreign terrorist organization. ${ }^{48}$ As a result, Abu Salha slipped through the cracks and returned to Syria. Upon his return to Syria, he fought for JN, conducting a suicide attack on a restaurant in Northern Syria in May 2014. ${ }^{49}$

However, in another, similar case, the FBI interdicted a former combatant in Syria who was attempting to travel back to jihadist-controlled territory after his return to the U.S. Sinh Vinh Ngo Nguyen, a California resident, traveled to Syria in December 2012 and fought for jihadist groups, returning to the U.S. in the spring of $2013 .{ }^{50}$ Shortly after his return, an undercover federal agent posing as an al-Qaeda recruiter reached out to Nguyen, and offered to help him return to

jihad by traveling to Pakistan. ${ }^{51}$ Nguyen was arrested in October 2013 and later sentenced to 13 years in federal prison for making false statements to the FBI and material support for terrorism. ${ }^{52}$

The effectiveness of these laws and strategies becomes exceptionally apparent when the situation in the U.S. is compared to the responses of other Western countries to returnees. One notable case is in the United Kingdom; the Home Office estimated in 2016 that over 400 of the country's 800 travelers had returned, of which only 54 (13.5\% of returnees) faced criminal charges. ${ }^{53}$ Intelligence sharing, updated criminal procedures, and policies for responding to returnees have all improved drastically in European countries since the outset of the Syrian and Iraqi conflicts. ${ }^{54}$ However, many of these policies were adopted too late to respond to the peak of the wave in foreign fighter travel, and have mixed records in successfully responding to returning foreign fighters. Even when criminal cases can be brought against returning travelers in Europe, conviction records are lower. ${ }^{55}$

However, the current U.S. strategy to address the threat of jihadist returnees is not failsafe. The de facto U.S. response has been to push returnees through the criminal justice system, charge them with violations of the material support statute, and sentence them accordingly. However, charges and sentences given to U.S. returnees have ranged drastically. In reality, lengthy prison sentences have been the exception, not the norm.

To date, eight returned travelers have been convicted or pleaded guilty to criminal charges, of which seven have received a prison sentence. Data are likely to shift as more cases are tried, but currently, the average prison sentence given to returnees is approximately ten years in prison. If cases where authorities declined to bring charges (thus, resulting in a returnee spending zero years in prison) are added, the average prison sentence for returnees in the U.S. is just under eight years. In comparison, individuals that attempted to travel to Syria and Iraq, but were apprehended during travel, received an average prison sentence of 14 years in prison. ${ }^{56}$

When sentences given to returnees are dissected on a case-by-case basis, the discrepancies are even more explicit. Only three of these cases (Mohamud, Khweis, and Nguyen) involved a material support charge; they are also the cases in which sentences are the longest $(22,20$, and 13 years in prison, respectively). However, 
the most common charge leveled against American returnees is not material support (under 18 U.S.C. $\$ 2339 \mathrm{~A}$ ); instead, it is making false statements (under 18 U.S.C. \$1001). If convicted, false statement charges carry a maximum sentence of five years in prison; if the enhancement for making a false statement in a terrorism case is pursued, the maximum penalty is eight years. ${ }^{57}$ In contrast, the maximum sentence for material support is 20 years. $^{58}$

Thus, based on this limited sample, building material support cases against returning travelers does not appear to be as effective or straightforward as initially anticipated. The conviction rate may be higher in the U.S. than in Europe, but many of the cases in the U.S. involved lesser charges with smaller sentences. This solution guarantees that returning travelers will be convicted, but contrary to popular belief, prosecutors in the U.S. cannot always rely on returnees receiving decades-long prison sentences. Inconsistencies in charging and sentencing reveal two critical flaws with the way that the U.S. has addressed returning travelers thus far.

First, several convicted jihadist travelers to Syria and Iraq will be released from prison in the coming years. No deradicalization or disengagement programs currently exist in U.S. prisons. Therefore, it is worth considering whether jihadist prisoners will reject their ways or continue to participate in jihadist groups following their release. ${ }^{59}$ Given the potential role for returnees to form nodes in networks of supporters, even with convicted returnees who will spend the next few decades in prison, it is also important to determine if they are attempting to network-build while incarcerated. ${ }^{60}$ As similar experiences in Europe prove, convicted jihadists using the prison and parole systems as a method of finding like-minded individuals, as well as radicalizing others, can be critical in forming future terrorist networks. ${ }^{61}$

Moreover, several of these cases show that in some instances, building a material support case against returned travelers is not possible. One substantial roadblock is gathering evidence about a traveler's activities in Syria or Iraq. Sometimes, actionable intelligence cannot translate into admissible evidence in a court of law. In the proverbial "fog of war" and the constellation of sub-state military actors in Syria and Iraq, it is often especially difficult to determine precisely which organization a traveler was allied with during their time in Syria and Iraq. ${ }^{62}$ In order to conclusively prove any material support charge, or the terrorism enhancement to false statements charges, prosecutors must provide substantial evidence that the traveler in question had connections to a designated foreign terrorist organization. The builtin defense for travelers is that although they may have provided support to a militant organization in Syria or Iraq, they did not support a designated organization.

If a returning traveler is not deemed to be highrisk, or material support charges are not available, it may be worth weighing the costs and benefits of non-prosecutorial options in addition to whichever lesser criminal charges can be applied. To provide a wide array of effective options, the U.S. must invest more political and financial resources into alternative and preventative counter-terrorism programs. This may not only decrease the recidivism risk from returned jihadist travelers, but also provide insights and potential solutions to countering the homegrown jihadist threat more broadly. 



\section{Addressing the Threat of American Jihadist Travelers}

$\mathrm{T}$ he challenges posed by American jihadist travelers are varied and complex. While the data and analysis provided in this study can help further our understanding, it is also important that they are applied to future policy and civil society efforts towards preventing jihadist travel. Despite the multifaceted nature of the issue, there are recurring themes and implications which can be useful in forming potential responses.

Although large-scale travel has now concluded, as the U.S. experience with jihadist travelers from the 1990s and 2000s suggests, there may be a future mobilization of travelers when new battlefields emerge. Policymakers must attain a solid understanding of the dynamics in jihadist travel that have developed across mobilizations so that the U.S. can respond adequately to future waves. To account for the complexity of the threat, the U.S. must develop multifaceted, innovative, and alternative approaches.

The risk that "homegrown" extremists will commit attacks on U.S. soil outweighs the risk of attacks from returning travelers.

Since 2011, there have been 22 jihadist attacks in the U.S. None of them were committed by a traveler who returned from Syria and Iraq. More to the point, only one of the 64 travelers is known to have returned to the U.S. for the purposes of committing an attack.

This is not to say that travelers do not pose any threat, or that the current approach of monitoring their activities is flawed. Yet, the risk of attacks from returning travelers is overshadowed by jihadists who never leave the U.S. This comparison is not only supported by research on the traveler contingent in Syria and Iraq, but studies of other jihadist mobilizations of Americans. ${ }^{1}$ However, there is evidence from previous periods of mobilization to suggest that returnees have assisted homegrown jihadists in attack planning and travel. Travelers who return from Syria and Iraq bring new contacts, skills, and status within jihadist movements. Policies must be supplemented with responses designed to prevent returning jihadists from facilitating the plots of others.

A multi-tier classification and review system is necessary to assess the threat posed by individual travelers.

Overall the U.S. utilizes a provisional, case-by-case approach to returning travelers. This allows for a degree of flexibility, but absent a framework for processing different types and categories of travelers, agencies default to prosecution. U.S. strategies should consider the differing risks, levels of disengagement, and appropriate responses to jihadist travelers.

This strategy should include tiered threat assessments, categorizations of travelers, and a variety of responses, spanning from traditional to non-traditional approaches. The appropriate responses to returning jihadist travelers should be determined by several factors, such as: age, background, personal connections to other jihadists, behavior prior to departing, their overseas activities, and their motivations for returning to the U.S.

In addition to these variables, this study's three categories of travelers can be instructive for authorities when determining responses to each case. Are they a pioneer or veteran of multiple conflicts? Have they built networks with like-minded supporters in the U.S. that may facilitate their re-entry into jihadist activity? Or are they loners who do not have the personal connections to reintegrate into jihadist networks? From such classifications, authorities could develop a range of policies and responses. 
The most pressing question for U.S. officials is whether a traveler is returning for the purposes of conducting an attack. Approaches should include threat assessments of travelers from the intelligence community, combined with input from overseas allies and partners, to assess this probability.

When travelers who are planning to commit an attack do return, the response should be clear cut: prosecution. However, the challenge is in determining appropriate measures for cases in which returnees do not intend to plan terrorist attacks. Law enforcement must distinguish between individuals who have completely disengaged from jihadism, and those who have not. Some travelers will return after surrendering to U.S. forces or renouncing their jihadist groups. This class of returnees, if leveraged correctly, can be crucial human intelligence sources. They can provide a window into the operations of jihadist organizations and other Westerners fighting overseas. However, these travelers have their own incentives and disincentives for providing information. Notably, they may view cooperation as a ticket to a reduced jail sentence or other privileges. Nonetheless, a record of cooperation with federal authorities may decrease the risk of recidivism.

More perplexing cases involve individuals who disengaged from the battlefield in Syria and Iraq, but not from jihadism or their group. These are high-risk cases for facilitation and terrorist recidivism. Law enforcement faces a difficult challenge in assessing whether their disengagement is genuine and lasting.

The U.S government also needs a strategy to respond to travelers who held ostensibly non-combatant roles in jihadist groups. In the wave of IS-related mobilization, whole families traveled to the group's territory in Syria and Iraq. Returning women and children travelers possess unique experiences, and may have different reintegration needs than adult male travelers. However, authorities should not essentialize their roles.

Women returnees, like their male counterparts, may downplay their involvement in a ploy to receive favorable treatment in judicial proceedings. Despite this, American policymakers should understand that women travelers often play essential roles in the operation of jihadist organizations. They should not be exempt from criminal liability for their actions merely because they are women, or because they served in non-combat roles. ${ }^{2}$

The U.S. government must work with nongovernmental partners (including, psychologists, sociologists, community leaders, and families) to prepare for the return of American children who were taken by their families or born in Syria and Iraq. While the U.S. has prosecuted individuals as young as 15 , the Department of Justice may decline to press legal charges against returning minors. There is currently no system in place to address this issue. These minors have spent their formative years engrossed in a culture that values death and espouses hatred for the West. A process of disengagement, or even deradicalization, is required for these individuals.

Prosecutions are a necessary, but insufficient strategy to respond to American jihadist travelers. In addition to convictions, the U.S. government must develop alternative responses, especially in the U.S. prison and parole systems.

The diverse nature of American travelers and returnees demonstrates that in most cases, criminal prosecution is warranted. However, it is not always the appropriate response. Article III criminal prosecution has heralded significant successes in the response to returning travelers. For instance, Abdirahman Sheik Mohamud received a 22-year sentence, the longest for any returnee from Syria or Iraq. Yet, these cases are exceptions to the norm. Strikingly, the prison sentence for convicted, successful travelers is, on average, four years less than the average sentence for individuals who attempted to travel but were apprehended.

Returning travelers have been convicted for several offenses. However, if a material support case cannot be established, remaining offenses usually carry much shorter prison sentences. Travelers' activities in Syria and Iraq are disguised by the "fog of war," and evidence from the battlefield may not be admissible in court. Thus, law enforcement is forced to pursue lesser charges as a fallback. In November 2017, NCTC Deputy Director 
Russell Travers addressed the potential downside of this approach: "if [travelers] are arrested and put in jail, the chances are that the sentences will be relatively light in some cases, and they will be out on the streets in a few years ... this is going to be recurring threat."

It is worth considering the costs and benefits of this approach. The amount of time that travelers convicted of a lesser offense spend in prison may be relatively negligible. Travelers also have the potential to build networks within the prison system, and have few incentives to disengage from jihadism while incarcerated.

To date, two individuals who were convicted of offenses related to their participation in jihadist groups in Syria and Iraq have already completed their sentences. Within the next five years, at least three more are scheduled for release. Currently, there are no deradicalization and disengagement programs targeted towards incarcerated terrorists in the U.S. federal prison system. In this regard, the U.S. lags behind many Western nations and must make such programs a priority. The alternative-allowing individuals convicted of terrorism-related offenses to serve out sentences without any deradicalization programming-is a band-aid solution that relies solely on the deterrent effect of prison sentences.

U.S. Bureau of Prisons officials have expressed concerns that individuals convicted of terrorism offenses may build support networks within prison and attempt to radicalize other inmates. ${ }^{4}$ European countries have had an especially difficult lesson to learn regarding terrorist networks that were partially or wholly facilitated in their prison systems. For instance, several members of the cell responsible for the 2015 Paris attacks and the 2016 bombings had previously been incarcerated, and two of them initially met one another in the same prison. ${ }^{5}$

Yet, perhaps in response to these failures in traditional criminal justice approaches, some European countries have developed innovative strategies aimed towards deradicalizing and re-integrating travelers. ${ }^{6}$ An instructive example is Denmark's Aarhus model. This program developed a four-stage process for returning travelers to utilize counseling services provided by a consortium of community leaders, psychologists, sociologists, former travelers, and their families. ${ }^{7}$

Another alternative option relies on the use of disengaged and deradicalized returnees in targeted interventions. This approach has been implemented in several European countries using former members of various types of extremist groups (including far-right extremists, white nationalists, criminal gang members, and jihadists). ${ }^{8}$ These options, due to the personnel they require, can fail without strict program guidelines, clear metrics of success, and careful risk assessments.

Some American returnees have expressed disillusionment with the false utopian vision offered by jihadist groups. The U.S. should consider leveraging these individuals in a more comprehensive way. In a very select number of cases, law enforcement should discreetly consider pursuing alternatives to prosecution for returning travelers who can use their experience to discourage future recruits. Prior to this decision, a comprehensive review of their intent and disillusionment with jihadism must be implemented.

Targeted intervention programs, including those that utilize returnees, have not been attempted on a large scale in the U.S. However, small-scale programs are underway to develop innovative approaches to address returnees and prevent future recruitment. Policymakers may consider scaling up these programs as part of a coherent national strategy. For example, an American returnee is currently involved in an experimental intervention program aimed towards deradicalizing other would-be travelers. ${ }^{9}$ The returnee has thus far succeeded in using the credibility gained from their experience to dissuade at least one other American from making similar mistakes. This program is not yet part of any national strategy, and the dedicated local officials who implement this program receive little federal support.

However, just like criminal prosecution, such alternative approaches should not be considered silver bullets. They are designed to augment the criminal justice process, not replace it. High-risk cases of travelers for whom alternative 
programs are not appropriate will certainly exist. For others, however, they may be worth considering.

Regulating online services (e.g. censorship, content and account deletion, restricting or banning privacymaximizing tools) may have limited utility in countering jihadist travel-facilitation networks.

Many governments are still struggling to adapt to the dynamic role of digital communications technologies in terrorist recruitment. Identifying and monitoring travelers was considerably simpler when they used open platforms to plan their travel arrangements. In many ways, the blatant openness of their support provided opportunities for surveillance and a window for law enforcement to interject through arrests. Recently, supporters of jihadist groups have primarily transitioned to online platforms that offer privacy-maximizing services (such as secure browsers, virtual private networks, protected email services, mobile security applications, and encrypted messengers). ${ }^{10}$

The U.S. government has repeatedly raised this concern. Authorities claim that as a result of terrorist supporters "going dark," law enforcement is less likely to prevent individuals from traveling to conflict zones or planning attacks. Acting Deputy Attorney General Rod Rosenstein argued that "'going dark' threatens to disable law enforcement and enable criminals and terrorists to operate with impunity. When police cannot access evidence, crime cannot be solved. Criminals cannot be stopped and punished." ${ }^{11}$ Some European countries have taken a more robust stance. For example, in October 2017 UK Home Secretary Amber Rudd introduced a plan to criminalize accessing and viewing jihadist material online. ${ }^{12}$ UK Prime Minister Theresa May and French President Emmanuel Macron have also considered laws to make social media service providers liable for failing to remove jihadist content from their platforms. ${ }^{13}$

These tougher stances were developed mainly in response to recent homegrown terrorist attacks in Western countries, and were adopted well after the peak of jihadist travel to Syria and Iraq. There is evidence that many travelers utilized digital communications technologies to help facilitate their journey. While some requests for regulations on these services have merit and may assist in reducing terrorist recruitment, they face multiple obstacles.

The impulse to ramp up online censorship by taking down social media accounts and content is understandable given the success of jihadist groups in the online environment. Removing jihadist supporters and propaganda from Twitter, Facebook or YouTube, now standard practice for these companies, helps to diminish the group's presence on open platforms. In the cases of budding jihadist sympathizers with no real-world connections to the group, censorship may ensure that IS propaganda and recruiters are now harder (albeit still possible) to access and contact.

However, while there is no doubt that ease of access to jihadist propaganda online was a factor in many cases analyzed in this report, there is little evidence to suggest that this was the primary motivation for their travel. In most cases, a range of factors, online and offline, pushed individuals to make their journeys. Even when travelers went online, they displayed an active understanding of how to circumvent existing censorship measures by using lesser-known social media platforms. On these alternative platforms, propaganda, content, and facilitators remained easily (if not equally) accessible.

Thus, while censorship efforts will continue, they should be done with an acknowledgement that the approach has several limitations. American jihadists who migrated to

82 | THE GEORGE WASHINGTON UNIVERSITY PROGRAM ON EXTREMISM 
lesser-known social media platforms found a similar amount of jihadist material and access to recruiters.

Mohamad Khweis' case indicates the full spectrum of measures that travelers have taken to not only evade online censorship and account deletion, but also mask both their online activities and international travel. FBI investigators found no less than four secure calling platforms, three end-to-end encrypted messaging applications, three VPN services, an anonymous browser, and a video downloading application on Khweis' mobile devices. ${ }^{14}$

Attempts to counter terrorist use of privacy- maximizing tools face even greater hurdles than online censorship. In December 2015, then-FBI director James Comey expressed his frustration that the Bureau was unable to access 109 encrypted messages between Garland attacker Elton Simpson and an "overseas terrorist." ${ }^{15}$ The issue has also become more pressing in Europe, with demands from politicians that popular applications which offer encryption, like WhatsApp and Telegram, cooperate more with authorities. ${ }^{16}$ In response, certain countries have requested "backdoor" access to encrypted messages. ${ }^{17}$

There is no doubt that these emerging communication tools are of immense benefit to terrorists. Encryption and government access, therefore, is likely to be the most complex and long-running of all the debates surrounding extremist use of the internet. With this in mind, encryption must also be understood outside of the narrow context of terrorism and counter-terrorism. Countless people use encryption and other privacy-maximizing services every day, mostly for benign reasons, and it is often an invaluable tool for dissidents living under oppressive regimes.

Even if it was beneficial to do so, it is likely too late to limit access to end-to-end encryption. ${ }^{18}$ Encryption is the future of digital communications. The technology is readily available, and new applications offering encryption are regularly developed. While possible technical solutions-including specific backdoor access to archived chats rather than live encrypted conversations-are beyond the scope of this report, there are many issues which must be considered if governments plan to regulate, weaken or ban these tools.

For instance, some companies offering privacymaximizing services will refuse to acquiesce to government requests. One notable example is Telegram, which claimed in a March 2017 statement that "Telegram has disclosed zero bytes of user data to third parties, including governments" and claimed that it has no intention of cooperating with any government requests for data. ${ }^{19}$ Moreover, the incentives and disincentives that help convince major technology companies to remove content or share data with governments may not apply to smaller social media providers. To counter terrorists' use of the internet in a rapidly-shifting online environment, the U.S. government must learn how to engage smaller (and more ideologically driven) companies. 



\section{Conclusion}

$\mathrm{T}$ his study's overview of the Americans who traveled to Syria and Iraq to join jihadist groups offers a number of contributions. Among them is the provision of a new set of categories that help to add further depth and nuance to our understanding of the nature of jihadist mobilization among Americans. By dividing the travelers between loners, networked travelers, and pioneers, the authors sought to explain both how and why they joined groups like IS. Not all travelers are motivated by the same factors, nor do they follow a single blueprint for how to successfully make the journey.

Their reasons for leaving the U.S. are as varied as their profiles. In some cases, they were motivated to travel primarily by their desire to fulfill perceived religious obligations. They wanted to reside in, and help cultivate, what they believed was the perfect Islamic society. Taken in by propaganda, they saw a land that was run by the law of God, ensuring divine justice and guaranteeing paradise for its members. Some suffered from an identity crisis that led them to question their place in America and their relationships with their non-Muslim fellow citizens. Others found themselves swept up by the febrile atmosphere created within their peer group, all of whom sought the excitement and adventure of fighting together to protect fellow Muslims. However, to ascribe one single motivating factor to any American traveler oversimplifies a complex process. There are less tangible, often serendipitous, causes which scholars and analysts often ignore.

The reasons why Americans have returned home, however, appear to be more prosaic. For many of the returnees, life in jihadist-held territory did not live up to their expectations. The propaganda, while enthralling, presented an idealized version of reality, meaning that their real-world experience upon arrival was often jarring. Living conditions were much harsher than they saw in the online magazines and videos, and the promises of companionship and camaraderie were rarely fulfilled. Instead, cultural clashes, bitter in-fighting and suspicion among recruits and leadership abounded. Many of the Americans had little to no combat experience and were assigned duties such as cleaning safehouses, cooking, and caring for the sick and injured. This was hardly the glamorous experience they anticipated, and some sought a way back to the comforts of home.

In at least one instance, however, a traveler returned to America intent on committing an attack. Abdirahman Sheik Mohamud was trained and sent back by JN and, had his plan been successful, it would have been the first terrorist attack in the country committed by a returnee from Syria or Iraq. However, this study finds that the returnee threat to the country thus far has been minimal. Besides Mohamud, the remaining eleven known returnees did not attempt attacks, according to current sources.

The U.S. is unique among other Western nations in this regard. While many of the most lethal IS-related attacks in countries like Belgium, France, and the UK have been executed by individuals trained by the group, the opposite is true here. At present, all of the major terrorist attacks in the U.S. since the establishment of IS have been perpetrated by Americans who did not travel to or receive training from a group. Comparatively, European jihadists have found it relatively easy to return home from Syria and Iraq.

Beyond attacks, however, returnees pose several security challenges. In prison, they may attempt to leverage their credibility as successful travelers to radicalize fellow inmates. Their relatively short sentences mean that most returnees may be out of prison in just under a decade. Given that the Bureau of Prisons does not currently offer any deradicalization or rehabilitation programs for jihadists, there is a likelihood that some returnees will attempt to rejoin the cause upon release. While they will likely be subject to intense scrutiny by the probation services, these individuals may either attempt to travel again, 
plot a domestic attack, or help to establish local jihadist networks. In Europe, for example, jihadist inmates have been known to make connections to underground criminal networks. ${ }^{1}$ Their newfound contacts assisted them with skills such as illegal weapon procurement, document forgery, human smuggling, and other illicit enterprises.

The statistics provided in this report also serve as an essential reminder of how IS mobilization has manifested itself in the U.S. Perhaps unsurprisingly, the figures related to American travelers closely mirror those of domestic IS supporters more broadly. Demographically, their profiles are similar. The majority of travelers are males with an average age of just under 27 years old. Methodological barriers to accurately assessing the number of women travelers notwithstanding, women represent only a fraction of the sample size. Per the information currently available, however, women play an outsized role and are heavily involved in creating and cultivating recruitment networks.

The figures also reveal that the vast majority of travelers are American citizens or permanent residents. The traveler phenomenon, like the domestic terrorist threat, is primarily homegrown. This finding is important for the government to consider as it continues to assess how counter-terrorism measures must adapt to this ever-evolving threat.

Authorities are understandably concerned about the uncertain number of travelers who remain at large. ${ }^{2}$ This contingent represents a serious threat, as some of them may act as nodes for American jihadist recruitment networks. As jihadist organizations face increased pressure in Syria and Iraq, several of them may also flee the region and join other affiliates or associated groups.

While the findings of this study provide a firm basis for understanding the traveler phenomenon, important research questions remain. For instance, if researchers can better understand why Westerners leave groups like IS, this data can be used to inform ongoing efforts to deter future recruitment. Research on the effectiveness of current targeted intervention programs involving formers, and how such interventions are conducted, could contribute significantly to ongoing prevention efforts in the West.

Moreover, this study has highlighted geographic areas in the U.S. with disproportionately high levels of jihadist mobilization. The most active location in the U.S. appears to be Minnesota, where more than a dozen Americans have joined or attempted to join IS. However, the dynamics of these types of areas are far better understood in Europe than they are in the U.S. An important avenue of possible future research is examining what factors are behind the relatively high degree of radicalization they have experienced.

This latest experience of American mobilization to overseas jihadist groups can provide a roadmap to policymakers and the public. If history is a guide, there will be another large-scale jihadist mobilization in the future. The U.S. must develop a proactive and comprehensive strategy to address jihadist travel, continuously adapting preexisting measures while developing more innovative approaches based on the lessons of the past six years. 


\section{Notes}

\section{Introduction}

1. Authors' interview with Federal Bureau of Investigation officials on October 24, 2017. This number includes travelers, attempted travelers, and participants of jihadist and non-jihadist groups.

2. Hoffman, Bruce. 2016. "The Global Terror Threat and Counterterrorism Challenges Facing the Next Administration." CTC Sentinel 9 (11). https://ctc.usma.edu/ posts/the-global-terror-threat-and-counterterrorismchallenges-facing-the-next-administration.

3. The Soufan Group, "Foreign Fighters: An Updated Assessment of the Flow of Foreign Fighters into Syria and Iraq." 2015. New York: The Soufan Group. http:// soufangroup.com/wp-content/uploads/2015/12/TSG ForeignFightersUpdate3.pdf.

4. Witte, Griff, Sudarsan Raghavan, and James McAuley. 2016. "Flow of Foreign Fighters Plummets as Islamic State Loses Its Edge." Washington Post, September 9, 2016, sec. Europe. https://www.washingtonpost.com/world/europe/flow-offoreign-fighters-plummets-as-isis-loses-its-edge/2016/ 09/09/ed3e0dda-751b-11e6-9781-49e591781754_story.html.

5. Malet, David. 2013. Foreign Fighters: Transnational Identity in Civic Conflicts. New York, NY: OUP USA. p. 9

6. Alexander, Audrey. 2016. "Cruel Intentions: Female Jihadists in America." Program on Extremism. https://cchs.gwu.edu/ sites/cchs.gwu.edu/files/downloads/Female\%20Jihadists\%20 in\%20America.pdf.

7. Stern, Jessica, and J.M. Berger. 2015. "ISIS and the ForeignFighter Phenomenon.” The Atlantic, March 8. https:// www.theatlantic.com/international/archive/2015/03/ isis-and-the-foreign-fighter-problem/387166.

8. Hegghammer, Thomas. 2013. "Should I Stay or Should I Go? Explaining Variation in Western Jihadists' Choice Between Domestic and Foreign Fighting.," American Political Science Review 107 (1), p. 6.

9. Cilluffo, Frank J., Jeffrey B. Cozzens, and Magnus Ranstorp. 2010. "Foreign Fighters: Trends, Trajectories \& Conflict Zones." George Washington University Homeland Security Policy Institute. https://chs.gwu.edu/sites/cchs.gwu.edu/ files/downloads/HSPI_Report_16.pdf. 29.

10. Dalgaard-Nielsen, Anja. 2010. "Violent Radicalization in Europe: What We Know and What We Do Not Know." Studies in Conflict \& Terrorism 33 (9): 797-814. doi:10.1 080/1057610X.2010.501423; Hegghammer, Thomas. 2010. "The Rise of Muslim Foreign Fighters: Islam and the Globalization of Jihad.” International Security 35 (3):
53-94. doi:10.1162/ISEC_a_00023; Schmid, Alex P. 2013. "Radicalisation, De-Radicalisation, Counter-Radicalisation: A Conceptual Discussion and Literature Review." ICCT Research Paper. International Centre for CounterTerrorism-The Hague. https://www.icct.nl/download/file/ ICCT-Schmid-Radicalisation-De-Radicalisation-CounterRadicalisation-March-2013.pdf.

11. Benmelech, Efraim, and Esteban F. Klor. 2016. "What Explains the Flow of Foreign Fighters to ISIS?” Working Paper 22190. National Bureau of Economic Research. doi:10.3386/w22190.

12. For instance, Hegghammer, Thomas. 2016. "Revisiting the Poverty-Terrorism Link in European Jihadism.” presented at the Society for Terrorism Research Annual Conference, Leiden, the Netherlands, November 8. http://hegghammer. com/_files/Hegghammer_-_poverty.pdf.

13. Johnson, Toni. 2011. "Muslims in the United States." Council on Foreign Relations. September 19. https://www. cfr.org/backgrounder/muslims-united-states.

14. Benmelech and Klor, "What Explains the Flow of Foreign Fighters to ISIS"

15. Archetti, Cristina. 2015. "Terrorism, Communication and New Media: Explaining Radicalization in the Digital Age.” Perspectives on Terrorism 9 (1). http://www.terrorismanalysts. com/pt/index.php/pot/article/view/401.

16. Ibid.

17. Berger, J. M. 2011. Jihad Joe: Americans Who Go to War in the Name of Islam. Washington, DC: Potomac Books, Inc. p. xi

18. Ibid.

19. Other notable figures include the "Blind Sheikh" Omar Abdel-Rahman, and the Pakistani sheikh Mubarek Ali Gilani. The 9/11 Commission Report: Final Report of the National Commission on Terrorist Attacks Upon the United States. 2011. Washington DC: Government Printing Office.

20. Ibid.

21. Ibid.

22. Prominent figures from this mobilization include Clement Hampton-El, who was later sentenced to 35 years in U.S. prison for his role in the 1993 World Trade Center bombing plot; Wadi el Hage, who is currently serving a life sentence for his role in the 1998 bombings of U.S. embassies in East Africa; and Daniel Patrick "Saifullah" Boyd, who after his return from Afghanistan organized a group of six family members and friends in North Carolina to travel overseas to participate in jihadist formations. These cases appear to be exceptions to the rule in terms of the 1980s Afghanistan 
mobilization - the vast majority of these travelers never returned to the U.S. Berger, J.M, Jihad Joe.

23. "Ohio Man Sentenced to 20 Years for Terrorism Conspiracy to Bomb Targets in Europe and the United States." 2009. Department of Justice Press Release. February 26. https://www.justice.gov/opa/pr/ohio-man-sentenced-20years-terrorism-conspiracy-bomb-targets-europe-andunited-states.

24. Ibid.

25. Ibid.

26. Jenkins, Brian. 2014. "When Jihadis Come Marching Home: The Terrorist Threat Posed by Westerners Returning from Syria and Iraq." RAND Corporation. https://www.rand. org/content/dam/rand/pubs/perspectives/PE100/PE130-1/ RAND_PE130-1.pdf.

27. Ibid.

28. Ibid.

29. Ibid.

30. Ibid.

31. Meleagrou-Hitchens, Alexander. 2011. "As American as Apple Pie: How Anwar Al-Awlaki Became the Face of Western Jihad." International Centre for the Study of Radicalisation. http://icsr.info/wp-content/uploads/2012/ 10/1315827595ICSRPaperAsAmericanAsApplePieHow AnwaralAwlakiBecametheFaceofWesternJihad.pdf.

32. Ibid.

33. Jenkins, "When Jihadis Come Marching Home"

34. Ibid.

35. Ibid.

36. Van Ginkel, Bibi et al. 2016. "The Foreign Fighters Phenomenon in the European Union: Profiles, Threats \& Policies." ICCT Research Paper. The Hague, Netherlands: International Centre for Counterterrorism- The Hague. https://www.icct.nl/wp-content/uploads/2016/03/ICCTReport_Foreign-Fighters-Phenomenon-in-the-EU_1April-2016_including-AnnexesLinks.pdf.

37. Ibid.

38. Doyle, Charles. 2016. "Terrorist Material Support: An Overview of 18 U.S.C. \$2339A and \$2339B.” CRS Report. Congressional Research Service. https://fas.org/sgp/crs/ natsec/R41333.pdf.

39. Ibid.

40. Ibid.

41. Rotella, Sebastian. 2016. "How Europe Left Itself Open to Terrorism.” Frontline. October 18. http://www.pbs.org/ $\mathrm{wgbh} /$ frontline/article/how-europe-left-itself-opento-terrorism.
42. Raymond, Catherine Zara. 2010. "Al Muhajiroun and Islam4UK: The Group behind the Ban." International Centre for the Study of Radicalisation. http://icsr.info/wp-content/uploads/2012/10/ 1276697989CatherineZaraRaymondICSRPaper.pdf; Reynolds, Sean C., and Mohammed M. Hafez. 2017. "Social Network Analysis of German Foreign Fighters in Syria and Iraq." Terrorism and Political Violence (forthcoming):1-26. https://doi.org/10.1080/09546553.2016.1272456. Lia, Brynjar, and Petter Nesser. 2016. "Jihadism in Norway: A Typology of Militant Networks in a Peripheral European Country." Perspectives on Terrorism 10 (6). http://www. terrorismanalysts.com/pt/index.php/pot/article/view/563.

43. Levin, Brian. 2015. "The Original Web of Hate: Revolution Muslim and American Homegrown Extremists." American Behavioral Scientist 59 (12):1609-30. https://doi. org/10.1177/0002764215588815.

44. Vidino, Lorenzo, Francesco Marone, and Eva Entenmann. 2017. "Fear Thy Neighbor: Radicalization and Jihadist Attacks in the West." Milan, Italy: Joint Program on Extremism, ICCT-The Hague, ISPI Report. https://extremism.gwu. edu/sites/extremism.gwu.edu/files/FearThyNeighbor\%20 RadicalizationandJihadistAttacksintheWest.pdf.

45. Klausen, Jytte. 2015. "Tweeting the Jihad: Social Media Networks of Western Foreign Fighters in Syria and Iraq." Studies in Conflict \& Terrorism 38 (1):1-22. https://doi.org/10. $\underline{1080 / 1057610 X .2014 .974948 .}$.

\section{Methodology and Statistics}

1. The Program provided U.S. government officials from four separate departments and agencies an opportunity to respond the findings of this report. In each instance, federal officials declined to provide additional information on the record, citing ongoing investigations and issues with classifications. However, those same officials did not argue that the release of this information would raise national security concerns.

2. There has been an extensive scholarly debate on the methodological upsides and downsides of using interview data from jihadists within terrorism studies. See, for example, Brannan, David W., Philip F. Esler, and N. T. Anders Strindberg. 2001. “Talking to 'Terrorists': Towards an Independent Analytical Framework for the Study of Violent Substate Activism." Studies in Conflict \& Terrorism 24 (1):3-24. https:// doi.org/10.1080/10576100118602. Nilsson, Marco. 2015. "Foreign Fighters and the Radicalization of Local Jihad: Interview Evidence from Swedish Jihadists." Studies in Conflict \& Terrorism 38 (5):343-58. https://doi.org/10.1080/ 1057610X.2015.1005459; Dawson, Lorne L., and Amarnath Amarasingam. 2017. "Talking to Foreign Fighters: Insights into the Motivations for Hijrah to Syria and Iraq." Studies in Conflict \& Terrorism 40 (3):191-210. https://doi.org/1 0.1080/1057610X.2016.1274216; Nilsson, Marco. 2017. "Interviewing Jihadists: On the Importance of Drinking Tea 
and Other Methodological Considerations." Studies in Conflict \& Terrorism 0 (0):1-14. https://doi.org/10.1080/1057610X. 2017.1325649 .

3. Khalil, James. 2017. "A Guide to Interviewing Terrorists and Violent Extremists." Studies in Conflict \& Terrorism 0 (0):1-15. https://doi.org/10.1080/1057610X.2017.1385182.

4. Lister, Charles R. 2016. The Syrian Jihad: al-Qaeda, the Islamic State and the Evolution of an Insurgency. London, UK: Oxford University Press.

5. Ibid.

6. "GW Extremism Tracker." 2017. Program on Extremism, December. https://extremism.gwu.edu/isis-america; Gilkes, Sarah. 2016. "Not Just the Caliphate: Non-Islamic State-Related Jihadist Terrorism in America." Program on Extremism. https://abcnews.go.com/images/US/gwuprogram-extremism-not-just-caliphate-20161206.pdf.

7. Amarasingam, Amarnath, and Colin Clarke. 2017. "Where Do ISIS Fighters Go When the Caliphate Falls?” The Atlantic, March 6, 2017. https://www. theatlantic.com/international/archive/2017/03/ isis-foreign-fighter-jihad-syria-iraq/518313.

8. "Foreign Terrorist Organizations." n.d. U.S. Department of State. Accessed October 31, 2017. http://www.state.gov/j/ ct/rls/other/des/123085.htm.

9. Wiktorowicz, Quintan. 2006. "Anatomy of the Salafi Movement." Studies in Conflict \& Terrorism 29 (3):207-39. https://doi.org/10.1080/10576100500497004.

10. Byman, Daniel. 2015. "Comparing Al Qaeda and ISIS: Different goals, different targets." Testimony before the Subcommittee on Counterterrorism and Intelligence of the House Committee on Homeland Security, April 29. https://www.brookings.edu/testimonies/comparing-alqaeda-and-isis-different-goals-different-targets.

11. Ibid.

12. Gartenstein-Ross, Daveed, and Aymenn Jawad al-Tamimi. 2015. "Druze Clues: Al Nusra's Rebranding and What It Means for Syria." Foreign Affairs, October 5, 2015. https://www.foreignaffairs.com/articles/syria/2015-1005/druze-clues.

13. Hassan, Hassan. 2016. "Jihadist Legacy Still Shapes Ahrar Al-Sham.” Tahrir Institute for Middle East Policy. June 3, 2016. https://timep.org/commentary/ jihadist-legacy-still-shapes-ahrar-al-sham.

14. Ibid.

15. Ibid.

16. Ibid.

17. "18 U.S. Code $\$ 2339$ A - Providing Material Support to Terrorists.” n.d. LII / Legal Information Institute. Accessed December 3, 2017. https://www.law.cornell.edu/uscode/ text/18/2339A.
18. Fritz, Jason, and Joseph K. Young. 2017. "Transnational Volunteers: American Foreign Fighters Combating the Islamic State." Terrorism and Political Violence (forthcoming):1-20. https://doi.org/10.1080/09546553.2017.1377075.

19. Anonymous. 2014. "I Learned to Fight Like an American at the FSA Training Camp in Jordan." Vice. April 3, 2014. https://www.vice.com/en_uk/article/wd4xe4/ syria-deraa-USA-Jordan-FSA-regime-CIA.

20. Romero, Dennis. 2014. "The Mysterious Case of L.A. Gangsters in Syria." L.A. Weekly. March 5, 2014. http://www.laweekly.com/news/ the-mysterious-case-of-la-gangsters-in-syria-4487924.

21. Engel, Richard, Ben Plesser, Tracy Connor, and Jon Schuppe. 2016. "The Americans: 15 Who Left the U.S. to Join ISIS.” NBC News. May 16, 2016. https://www.nbcnews.com/storyline/isis-uncovered/ americans-15-who-left-united-states-join-isis-n573611.

22. The authors were the first to publicly identify Abu Hamza al-Amriki as Zulfi Hoxha. He appeared in a segment of a video produced by IS' media division in Iraq in May 2017. Against the backdrop of a weapons storage facility, he displayed IS' newest weapons technology and encouraged sympathizers in the U.S. to conduct attacks. This identification was confirmed by a U.S. senior law enforcement official during an interview with the authors in December 2017.

23. Authors' interview with returned traveler, May 2017.

24. Engel et. al., "The Americans: 15 Who Left the U.S. to Join ISIS."

25. Most famously, Shawn Parson, a citizen of Trinidad and Tobago who became an IS fighter and recruiter, took the kunya Abu Khalid al-Amriki.

26. This statistic is based on analysis of the 52 fighters in the sample with known ages.

27. "Criminal Complaint." 2015. USA v. Reza Niknejad, United States District Court for the Eastern District of Virginia. Case: 1:15-mj-00325-IDD. https://extremism.gwu.edu/sites/ extremism.gwu.edu/files/Niknejad\%20Complaint.pdf.

28. Mohamad Kodaimati is older than Kary Kleman, although his exact age is unknown.

29. Weiss, Michael, Georg Heil, and Paul Cruickshank. 2017. "American 'Convert' Who Lived in ISIS Territory Detained by Turkey." CNN. April 28, 2017. http://www.cnn.com/ 2017/04/26/us/american-detained-turkey/index.html.

30. Ibid.

31. "Jihadist women, a threat not to be underestimated." 2017. General Intelligence and Security Service (AIVD), Ministry of the Interior and Kingdom Relations, Kingdom of the Netherlands. https://english.aivd.nl/publications/ publications/2017/12/14/publication-jihadist-women-athreat-not-to-be-underestimated. 
32. Gaub, Florence, and Julia Lisecka. 2016. "Women in Daesh: Jihadist 'cheerleaders', Active Operatives?” Brief Issue 27. EU Institute for Security Studies. https://www.iss.europa. eu/sites/default/files/EUISSFiles/Brief_27_Women_in_ Daesh.pdf.

33. BBC News. 2013. "US Woman Killed Fighting in Syria," May 31, 2013, sec. Middle East. http://www.bbc.com/news/ world-middle-east-22727911.

34. Ibid.

35. Ibid.

36. Hall, Ellie. 2015. "Gone Girl: An Interview With An American In ISIS.” BuzzFeed. April 17, 2015. https://www.buzzfeed.com/ellievhall/gone-girlan-interview-with-an-american-in-isis.

37. Ibid.

38. Ibid.

39. Authors' interview with Muthana family member, June 2016.

40. Engel, Richard, Ben Plesser, and Tracy Connor. 2016. "An American ISIS Cell: The Story of 3 U.S. Recruits." NBC News. May 18, 2016. https://www.nbcnews.com/ storyline/isis-uncovered/american-isis-cell-story-3-u-srecruits-n573831.

41. Ibid.

42. Ibid.

43. Ibid.

44. Ibid.

45. Alexander, "Cruel Intentions: Female Jihadists in America."

46. Ibid.

47. This method is drawn from other estimates of foreign fighter travel rates, including Benmelech and Klor, "What Explains the Flow of Foreign Fighters to ISIS?"; and Rosenblatt, Nate. 2016. “All Jihad Is Local: What ISIS’ Files Tell Us About Its Fighters.” New America Foundation. https://www.newamerica.org/international-security/ policy-papers/all-jihad-is-local.

48. To illustrate this skew, the state with the highest rate when states with less than two travelers are included is Maine, where there was one case of travel, but less than 2,000,000 people, only 2,000 of which are Muslims. Maine's rate of travel was seven times the national average.

49. States with higher rates, but less than two travelers include Maine, Tennessee and Alabama.

50. All state and metropolitan area total population figures referenced in this study are derived from the 2016 projections from the U.S. Census. https://www.census.gov/topics/ population/data.html. All state and metropolitan area estimates of Muslim population are derived from the 2010 U.S. Religion Census. http://www.usreligioncensus.org.
51. Cities with one case of travel, and higher rates than the cities listed above include Birmingham, Alabama; Portland, Maine; and Chattanooga, Tennessee.

52. Bakker, Edwin, and Mark Singleton. 2016. "Foreign Fighters in the Syria and Iraq Conflict: Statistics and Characteristics of a Rapidly Growing Phenomenon.” In Foreign Fighters under International Law and Beyond, edited by Andrea De Guttry, Francesca Capone, and Christophe Paulussen, 9-25. The Hague, Netherlands: T.M.C. Asser Press.

53. Ibid.

54. Khalil, Phyl, and Michael Noonan. 2014. "North American Foreign Fighters.” Journal for Deradicalization 1:66-96. http://journals.sfu.ca/jd/index.php/jd/article/view/6.

55. Bakker and Singleton, "Foreign Fighters in the Syria and Iraq Conflict."

56. There is insufficient evidence to classify 18 out of the 64 travelers $(28.1 \%)$ in the sample under a particular category.

\section{Category 1: Pioneers}

1. "Indictment." 2015. USA v. Ramiz Ziyad Hodzic, et al. United States District Court for the Eastern District of Missouri, Case: 4:15-cr-00049. https://extremism.gwu.edu/sites/ extremism.gwu.edu/files/Harcevic\%20Indictment.pdf.

2. Ibid.

3. Ibid.

4. "RAMO ABDULLAH PAZARA: Srpski Ratnik I Islamski Fanatik." 2015. Slobodna-Bosna.ba. February 19, 2015. http://www.slobodna-bosna.ba/vijest/19266/ramo_ abdullah_pazara_srpski_ratnik_i_islamski_fanatik.html.

5. Hughes, Seamus, and Bennett Clifford. 2017. "First He Became an American-Then He Joined ISIS.” The Atlantic, May 25, 2017. https://www. theatlantic.com/international/archive/2017/05/ first-he-became-an-americanthen-he-joined-isis/527622.

6. "Waiver of Indictment/Plea to Information." 2015. USA v Jasminka Ramic. United States District Court for the Eastern District of Missouri, Case: 4:15-cr-00049, p. 17

7. “Judgement." 2013. Prosecutor v. Mico Stanisic and Stojan Zupljanin. International Criminal Tribunal for the former Yugoslavia (ICTY), Case IT-08-91-T http://www.icty. org/x/cases/zupljanin_stanisicm/tjug/en/130327-1.pdf.

8. Ibid.

9. Sloboda-Bosna.ba, “"RAMO ABDULLAH PAZARA: Srpski Ratnik I Islamski Fanatik."

10. Ibid

11. Ibid

12. In 2016, a Georgia man who also served in the Bosnian Serb Army was convicted of obtaining U.S. citizenship by providing false and fraudulent information on a naturalization

90 | THE GEORGE WASHINGTON UNIVERSITY PROGRAM ON EXTREMISM 
application and sentenced to more than four years in prison. "Georgia Man Convicted of Immigration Fraud for Failing to Disclose Role in Bosnian Prison Camp." 2016. DOJ Press Release. May 26, 2016. https://www.justice.gov/opa/pr/ georgia-man-convicted-immigration-fraud-failingdisclose-role-bosnian-prison-camp.

13. Hughes and Clifford, "First He Became an American"

14. Ibid.

15. "Nihad Rosic| MMA Fighter Page." Tapology. Accessed November 20, 2017. https://www.tapology.com/ fightcenter/fighters/19267-nihad-rosic.

16. "Detention Hearing." 2015. USA v. Nihad Rosic, United States District Court for the Eastern District of Missouri, Case: 4:15-cr-00049, p. 6. https://extremism.gwu.edu/sites/ extremism.gwu.edu/files/Rosic\%20Detention\%20 Hearing\%20Transcript.pdf.

17. Ibid., pp. 11-12

18. Ibid., pp. 11-12

19. Moore, Doug, and Laurie Skrivan. 2013. "Making St. Louis Home: The Bosnian Resettlement 20 Years Later.” Stltoday. com. June 22, 2013. http://www.stltoday.com/news/ multimedia/special/making-st-louis-home-the-bosnianresettlement-years-later/html_dafa620f-9408-5daf-b123$\underline{1 \mathrm{~b} 2 \mathrm{ee} 29 \mathrm{fda} 56 . \mathrm{html}}$.

20. Patrick, Robert. 2015. "Allegations of St. Louis Terrorism Support Rooted Back in Bosnian War.” Stltoday.com. April 11, 2015. http://www.stltoday.com/news/local/crime-andcourts/allegations-of-st-louis-terrorism-support-rootedback-in-bosnian/article_0a3b08c5-29da-5f7c-ab4eb281f086f29f.html.

21. Ibid.

22. Ibid.

23. Ibid.

24. Ibid.

25. Gutman, Roy. 2012. "Bosnians Watching Syria with a Sense of Having Been There.” McClatchy. April 10, 2012. http://www.mcclatchydc.com/news/nation-world/world/ article24727666.html.

26. Azinovic, Vlado, and Muhammad Jusic. 2016. “The New Lure of the Syrian Civil War- The Foreign Fighters Bosnian Contingent." Sarajevo, Bosnia and Herzegovina: Atlantic Intiative. http://www.atlanticinitiative.org/images/The New_Lure_of_the_Syrian_War_The_Foreign_Fighters Bosnian_Contingent.pdf.

27. Patrick, "Allegations of St. Louis Terrorism Support Rooted Back in Bosnian War."

28. Ibid.

29. Ibid.

30. "Indictment," USA v. Ramiz Ziyad Hodzic, et al.
31. "Detention Hearing," USA v. Nihad Rosic.

32. Hughes and Clifford, "First he Became an American."

33. Ibid.

34. "Indictment," USA v. Ramiz Ziyad Hodzic, et al.

35. Ibid.

36. Ibid.

37. Ibid.

38. Ibid.

39. Ibid.

40. "Six Bosnian Natives Charged With Providing Material Support To Terrorists.” 2015. DOJ Press Release.

February 6, 2015. https://www.justice.gov/usao-edmo/ $\mathrm{pr} /$ six-bosnian-natives-charged-providing-materialsupport-terrorists.

41. Author's interview with Dr. Vlado Azinovic, May 23, 2017.

42. al-Shishani, Murad Batal. 2013. "Obliged to Unite under One Banner': A Profile of Syria's Jaysh Al-Muhajireen Wa'l-Ansar.” Jamestown Foundation. April 19, 2013. https://jamestown.org/ program/obliged-to-unite-under-one-banner-a-profile-ofsyrias-jaysh-al-muhajireen-wal-ansar.

43. Ibid.

44. Flood, Derek Henry. 2015. "The Islamic State Raises Its Black Flag Over The Caucasus.” CTC Sentinel 8 (6):1-5.

45. Ibid.

46. Zuvela, Maja. 2007. "Three Jailed in Bosnia for Planning Suicide Attack.” Washington Post, January 10, 2007. http://www.washingtonpost.com/wp-dyn/content/ article/2007/01/10/AR2007011001025.html.

47. “U Iraku Poginuo Bajro Ikanović, Državljanin BiH.” 2016. Vijesti.ba. March 23, 2016. http://vijesti.ba/clanak/ 302774/u-iraku-poginuo-bajro-ikanovic-drzavljanin-bih

48. "Treasury Sanctions Major Islamic State of Iraq and the Levant Leaders, Financial Figures, Facilitators, and Supporters." 2015. US Department of the Treasury Press Center. September 29, 2015. https://www.treasury.gov/ press-center/press-releases/Pages/j10188.aspx.

49. "Hteo Je Da Pogine U Svetom Ratu. Nismo Uspeli Da Ga Odgovorimo.” 2014. Blic.rs, January 9, 2014. http://www. blic.rs/vesti/tema-dana/hteo-je-da-pogine-u-svetomratu-nismo-uspeli-da-ga-odgovorimo/42kr1q9.

50. “Arraignment/Detention Hearing.” USA v. Mediha Salkicevic. United States District Court for the Eastern District of Missouri, Case: 4:15-cr-00049. https://extremism. gwu.edu/sites/extremism.gwu.edu/files/Salkicevic\%20 Arraignment\%20Text.pdf.

51. Abdullah Ramo Mudzhahid, 2014. Facebook post, January 24.

52. Abdullah Ramo Mudzhahid, 2013. Facebook post, October. 
53. "Indictment," USA v. Ramiz Ziyad Hodzic, et al.

54. Ibid.

55. Ibid.

56. Abdullah Ramo Mudzhahid, 2014. Facebook post, May 7.

57. Beganović, Ezher. 2014. "U Siriji Poginuo I Ramo Pazara Iz Teslića.” SAFF, September 24, 2014. http://saff. $\mathrm{ba} / \mathrm{u}$-siriji-poginuo-i-ramo-pazara-iz-teslica.

58. Rumiyah. 2017. “Among the Believers Are Men,” April 2017.

59. Ibid.

60. Cruickshank, Paul. 2017. "ISIS Lifts Veil on American at Heart of Its Propaganda Machine." CNN. April 7, 2017. http://www.cnn.com/2017/04/06/middleeast/isis-americanpropaganda-editor/index.html.

61. McPhee, Michele, and Brian Ross. 2014. "Official: American May Be Key in ISIS Social Media Blitz.” ABC News. September 3, 2014. http://abcnews.go.com/blogs/ headlines/2014/09/official-american-may-be-key-in-isissocial-media-blitz.

62. Anderson, Karen. 2014. "FBI on Mass. Terror Suspect: 'Don't Know Where He Is, What He's Doing.” WCVB. October 15, 2014. http://www.wcvb.com/article/fbi-onmass-terror-suspect-don-t-know-where-he-is-what-he-sdoing/8209979.

63. Ibid.

64. Ibid.

65. Ibid.

66. Ibid.

67. Ibid.

68. "Superseding Indictment." 2009. USA v. Tarek Mehanna and Ahmad Abousamra. United States District Court for the District of Massachusetts. Case: 09-CR-I0017.

69. Singman, Brooke. 2015. "Moderate Imam Reveals How Radicals Won Battle for Soul of Boston Mosques." Fox News. July 26, 2015. http://www.foxnews.com/us/2015/07/22/ moderate-imam-reveals-how-radicals-won-battle-for-soulboston-mosques.html.

70. Ibid.

71. Ibid.

72. "Superseding Indictment." USA v. Tarek Mehanna and Ahmad Abousamra.

73. "Affidavit." 2009. USA v. Tarek Mehanna and Ahmad Abousamra. United States District Court for the District of Massachusetts. Case: 09-CR-I0017.

74. "Superseding Indictment." USA v. Tarek Mehanna and Ahmad Abousamra.

75. Ibid.
76. "Government Sentencing Memorandum." 2012. USA v. Tarek Mehanna. United States District Court for the District of Massachusetts. Case: 09-CR-I0017.

77. Ibid.

78. Valencia, Milton. 2011. "Mehanna Friend Said to Seek Camps for Training." The Boston Globe, November 16, 2011. https://www.bostonglobe.com/metro/2011/11/16/ man-who-trained-terrorist-testifies-gave-mehannaassociate-contacts-yemen/Xtg5EQTfJNj8RqUHCOnrRL/ story.html.

79. "Superseding Indictment." USA v. Tarek Mehanna and Ahmad Abousamra.

80. Ibid.

81. Ibid.

82. Ibid.

83. Lavoie, Denise. 2011. "Witness Says Mass. Men Discussed Mall Shooting." Boston.com, November 28, 2011. http://archive.boston.com/news/local/massachusetts/ articles/2011/11/28/witness_in_mass_terror_case_sought_ terror_camp.

84. "Superseding Indictment." USA v. Tarek Mehanna and Ahmad Abousamra.

85. Ibid.

86. Ibid.

87. Ibid.

88. Ibid.

89. Ibid.

90. "Indictment." 2009. USA v. Tarek Mehanna and Ahmad Abousamra. United States District Court for the District of Massachusetts. Case: 09-CR-I0017.

91. Ibid.

92. Ibid.

93. Ibid.

94. Ibid.

95. Anderson, “'FBI on Mass. Terror Suspect: 'Don't Know Where He Is, What He’s Doing."

96. "Indictment." USA v. Tarek Mehanna and Ahmad Abousamra.

97. "Tarek Mehanna Sentenced in Boston to 17 Years in Prison on Terrorism-Related Charges." 2012. FBI. April 12, 2012. https://www.fbi.gov/boston/press-releases/2012/ tarek-mehanna-sentenced-in-boston-to-17-years-inprison-on-terrorism-related-charges.

98. "FBI Engages Social Media in Terrorist Manhunt." 2012. Public Radio International. October 4, 2012. https://www.pri.org/stories/2012-10-04/ fbi-engages-social-media-terrorist-manhunt.

92 | THE GEORGE WASHINGTON UNIVERSITY PROGRAM ON EXTREMISM 
99. "Wanted Fugitive Ahmad Abousamra Added to the FBI's Most Wanted Terrorists List." 2013. FBI. December 18, 2013. https://www.fbi.gov/boston/press-releases/2013/ wanted-fugitive-ahmad-abousamra-added-to-the-fbis-mostwanted-terrorists-list.

100. McPhee and Ross, "Official: American May Be Key in ISIS Social Media Blitz."

101. Rumiyah, "Among the Believers Are Men."

102. Ibid.

103. Ibid.

104. Ibid.

105. Ibid.

106. Ibid.

107. Joscelyn, Thomas. 2017. "How a US Citizen Became a Key Player in the Islamic State's Rivalry with Al Qaeda." FDD's Long War Journal. April 7, 2017. https://www.longwarjournal.org/ archives/2017/04/how-a-us-citizen-became-a-key-playerin-the-islamic-states-rivalry-with-al-qaeda.php.

108. Abousamra, Ahmad (Abu Maysarah ash-Shami). 2016. "Jews of Jihad: Zawahiri's Al Qaeda." https://www. longwarjournal.org/wp-content/uploads/2017/04/Arabicversion-of-Jews-of-Jihad.pdf.

109. Joscelyn, "How a US Citizen Became a Key Player in the Islamic State's Rivalry with Al Qaeda"

110. Ibid.

111. 'ISIS Movie Maker, Documentary Producer 'Killed' in Iraq Airstrike." 2015. Al Arabiya. May 31, 2015. http://english. alarabiya.net/en/News/middle-east/2015/05/31/ISISmovie-maker-and-documentary-producer-die-in-Iraqiairstrike.html.

112. Ibid.

113. Rumiyah, "Among the Believers Are Men."

114. Rumiyah. Issue 1, September 2016.

115. Warrick, Joby. 2016. "ISIS's Second-in-Command Hid in Syria for Months. The Day He Stepped Out, the U.S. Was Waiting." Washington Post, November 28, 2016, sec. National Security. https://www.washingtonpost.com/ world/national-security/isiss-second-in-command-hidin-syria-for-months-the-day-he-stepped-out-the-us-waswaiting/2016/11/28/64a32efe-b253-11e6-840f-e3ebab6bcdd3_story.html.

116. BBC News. 2016. "US Strike 'Kills IS Propaganda Chief," September 16, 2016, sec. Middle East. http://www.bbc. com/news/world-middle-east-37390408.

117. Rumiyah, "Among the Believers Are Men."

118. Abousamra, Ahmad (Abu Sulayman ash-Shami). 2017. "The Bliss of a Martyr." Rumiyah, April 2017.
119. Cruickshank, "ISIS Lifts Veil on American at Heart of Its Propaganda Machine."

120. Rumiyah, "Among the Believers Are Men."

121. Ibid.

122. Ibid.

123. Ibid.

124. Yusuf, Hamza. 2016. "When Evil Fails." Sandala (blog). July 31, 2016. https://sandala.org/when-evil-fails.

\section{Category 2: Networked Travelers}

1. McEnroe, Paul, and Allison Sherry. 2015. "Minnesota Leads the Nation in Would-Be ISIL Terrorists from U.S., Report Finds." Star Tribune, September 29. http://www.startribune. com/minnesota-leads-the-nation-in-would-be-isil-terroristsfrom-u-s-report-finds/329942131.

2. "U.S. Attorney: We Have a Terror-Recruiting Problem in Minnesota." 2015. NBC News. April 20, 2015. https://www. nbcnews.com/dateline/video/u-s-attorney-we-have-aterror-recruiting-problem-in-minnesota-430813251584.

3. Yuen, Laura, and Sasha Aslanian. 2013. "Minnesota Pipeline to Al-Shabab.” Minnesota Public Radio News. September 25, 2013. http://minnesota.publicradio.org/projects/ongoing/ somali_timeline.

4. Ibid.

5. Ibid.

6. Perez, Evan, and Shimon Prokupecz. 2015. "Minneapolis Men Allegedly Trying to Join ISIS Highlight Role of American Recruiter." CNN. April 20, 2015. http://www.cnn. com/2015/04/20/politics/isis-minnesota-arrests-abdi-nur/ index.html.

7. Ibrahim, Mukhtar M. 2017. “As Life's Pressures Mounted, He Left Minnesota for ISIS.” Minnesota Public Radio News, December 6, 2017. https://www.mprnews.org/story/ 2017/12/06/minnesota-isis-fighter-abdifatah-ahmedcourt-documents.

8. Ibid.

9. "Affidavit in Support of Application for a Search Warrant." 2015. United States District Court for the District of Minnesota. Case: 014-mj-00973, pp.8-9.

10. Ibid. Where possible, direct quotes from social media communications are presented in their original format and phrasing without edits to spelling and grammar.

11. "Details Emerge About Douglas McCain, American Jihadist Killed in Syria." 2014. VOA. August 27, 2014. https://www.voanews.com/a/us-man-suspected-of-fightingalongside-militants-killed-in-syria/2429355.html.

12. Omar, Ammar Cheikh, and Saphora Smith. 2014. “ISIS' Douglas McCain, Best Friend Troy Kastigar Both Waged Jihad.” NBC News. August 27, 2014. 
https://www.nbcnews.com/news/world/isis-douglas-mccainbest-friend-troy-kastigar-both-waged-jihad-n190001.

13. $V O A$, "Details Emerge About Douglas McCain, American Jihadist Killed in Syria."

14. "Affidavit in Support of Application for a Search Warrant," United States District Court for the District of Minnesota, p.10.

15. Ibid., p. 10

16. Ibid., p. 21

17. Yuen, Laura, Mukhtar Ibrahim, and Sasha Aslanian. 2015. "From MN Suburbs, They Set out to Join ISIS." Minnesota Public Radio News, March 25, 2015. https://www.mprnews. org/story/2015/03/25/minnesota-teens-isis.

18. "Affidavit in Support of Application for a Search Warrant," United States District Court for the District of Minnesota. p. 22

19. Ibid., p. 23

20. Ibid., p. 23

21. Ibid., p. 23

22. McCain used Duale Khalid as his name on Twitter, and Duale ThaSlaveofAllah on Facebook. His Twitter handle was @iamthetooth. Tellingly, the Karie brother that attempted to visit him in San Diego also referred to him as "Tooth." Ibid; $V O A$, "Details Emerge About Douglas McCain, American Jihadist Killed in Syria."

23. Ibid., p. 22

24. Huncar, Andrea. 2015. "3 Canadians Believed Killed Fighting for ISIS.” CBC News. January 14, 2015. http://www.cbc.ca/ news/canada/edmonton/3-isis-recruits-from-edmontonbelieved-killed-1.2901146.

25. "Affidavit in Support of Application for a Search Warrant," United States District Court for the District of Minnesota, pp. 13-23

26. Ibid., pp. 13-14

27. Ibid., pp. 14-15

28. Ibid., pp. 14-15

29. VOA, "Details Emerge About Douglas McCain, American Jihadist Killed in Syria."

30. Ibrahim, "As Life's Pressures Mounted, He Left Minnesota for ISIS.”

31. Huncar, "3 Canadians Believed Killed Fighting for ISIS."

32. Temple-Raston, Dina. 2017. "An American Teen Tried to Join ISIS. Then Came His Second Chance." New York Magazine. November 26, 2017. http://nymag.com/daily/ intelligencer/2017/11/abdullahi-yusuf-isis-syria.html.

33. Ibid.

34. Ibid.
35. "Criminal Complaint." 2014. USA v. Abdullahi Yusuf and Abdi Nur. United States District Court for the District of Minnesota. Case: 14-mj-1024. https://extremism.gwu.edu/ sites/extremism.gwu.edu/files/Yusuf\%20Criminal\%20 Complaint.pdf, pp. 11-13

36. Ibid., p. 13

37. Ibid., pp. 4-6

38. Ibid., p. 6

39. Ibid., pp. 7-8

40. Ibid., pp. 11-12

41. Ibid., pp. 9-11

42. Ibid., pp. 13-15

43. Ibid., pp. 15-16

44. Meleagrou-Hitchens, Alexander, and Seamus Hughes. 2017. "The Threat to the United States from the Islamic State's Virtual Entrepreneurs." CTC Sentinel 10 (3). https://www. ctc.usma.edu/posts/the-threat-to-the-united-statesfrom-the-islamic-states-virtual-entrepreneurs.

45. Hassan surrendered to Somali government forces in November 2015. Joseph, Dan, and Harun Maruf. 2015. "American Al-Shabab, Nabbed in Somalia, Denies IS Links." VOA. December 8, 2015. https://www.voanews.com/a/ american-al-shabab-arrested-in-somalia-denies-links-tois/3093529.html.

46. "Criminal Complaint," USA v. Abdullahi Yusuf and Abdi Nur, p. 16

47. Ibid., p. 16

48. Ibid., p. 17

49. "Criminal Complaint." 2016. USA v. Mohamed Ali Amiin Roble. United States District Court for the District of Minnesota. Case: 16-mj-584. https://extremism.gwu.edu/ sites/extremism.gwu.edu/files/Roble\%20Criminal\%20 Complaint\%2C\%20Signed\%20Affidavit.pdf, p. 5

50. Ibid, pp. 5-7

51. Ibid. pp. 8-9

52. Ibid., p. 9

53. Ibid., pp. 10-11

54. Ibid., pp. 11-12

55. Ibid., pp. 13-14

56. Shane, Scott. 2015. "From Minneapolis to ISIS: An American's Path to Jihad." The New York Times, March 21, 2015, sec. Middle East. https://www.nytimes.com/2015/ 03/22/world/middleeast/from-minneapolis-to-isis-anamericans-path-to-jihad.html.

57. Ibid.

58. "Criminal Complaint." 2015. USA v. Mohamed Abdihamid Farah et. al. United States District Court for the District of

94 | THE GEORGE WASHINGTON UNIVERSITY PROGRAM ON EXTREMISM 
Minnesota. Case: 0:15-cr-00049. https://extremism.gwu. edu/sites/extremism.gwu.edu/files/Omar\%20Criminal\%20 Complaint.pdf, p. 13

59. Ibid., p. 13

60. Ibid., p. 14

61. Ibid., p. $14-15$

62. Ibid., p. $14-15$

63. "Criminal Complaint." 2015. USA v. Abdirizak Mohamed Warsame. United States District Court for the District of Minnesota. Case: 0:15-mj-00978. https://extremism.gwu. edu/sites/extremism.gwu.edu/files/Warsame\%20Complaint. pdf, pp. 9-10.

64. "Criminal Complaint." USA v. Mohamed Abdihamid Farah et. al., pp. 14-16

65. Ibid., p. 15

66. Ibid., p. 15-16

67. Ibid., p. 16

68. Ibid., p. 16

69. Ibid., pp. 17-21

70. Ibid., pp. 19-21

71. Ibid., pp. 22-23

72. Ibid., pp. 22-24

73. Ibid., pp. 24-29

74. Ibid., pp. 25-26

75. Ibid., p. 26

76. Ibid., p. 29

77. Ibid., p. 29

78. Shane, Scott. 2015. "6 Minnesotans Held in Plot to Join ISIS." The New York Times, April 20, 2015, sec. U.S. https://www. nytimes.com/2015/04/21/us/6-somali-americansarrested-in-isis-recruiting-case.html.

79. McEnroe, Paul. 2015. "Twin Cities Suspect Arrested by FBI Was Pulled off Flight to Middle East.” Star Tribune. February 5. http://www.startribune.com/twin-cities-suspect-arrested-by-fbi-was-pulled-off-flight-to-middle-east/290964081.

80. Montemayor, Stephen. 2017. "After Prison, Will Minnesota's ISIS Defendants Come out Better or Worse?” Star Tribune. July 1. http://www.startribune.com/afteryears-in-prison-will-minnesota-s-isis-defendants-come-outbetter-or-worse/432015773.

81. Temple-Raston, "An American Teen Tried to Join ISIS. Then Came His Second Chance.”

82. Ibid.

83. Yuen, Laura, Mukhtar Ibrahim, and Sasha Aslanian. 2015. "Called to Fight: Minnesota's ISIS Recruits." Minnesota
Public Radio News, March 25. https://www.mprnews.org/ story $/ 2015 / 03 / 25 /$ minnesota-isis.

84. "Sentencing Position of the United States of America." USA v. Abdullahi Mohamed Yusuf. United States District Court for the District of Minnesota. Case: 0:15-cr-00046. p. 8

85. "Criminal Complaint." USA v. Yusra Ismail. United States District Court for the District of Minnesota. Case: 0:14-mj01047. https://extremism.gwu.edu/sites/extremism.gwu. edu/files/Ismail\%20Criminal\%20Complaint.pdf.

86. Montemayor, Stephen. 2017. "Feds Have at Least Six Open Cases Looking at ISIS Support in Minnesota." Star Tribune. September 9. http://www.startribune.com/ on-vacation-in-morocco-normandale-student-madebreak-for-isis/443462893.

87. Littlefield, Dana. 2016. "Syrian Gets 8 Years for Lying to U.S. Officials about His Ties to Terrorism.” LA Times, March 14, 2016. http://www.latimes.com/local/california/la-me-0315san-diego-terrorism-20160315-story.html.

88. Ibid.

89. "Criminal Complaint and Affidavit." 2015. USA v. Mohamad Saeed Kodaimati, United States District Court for the Southern District of California. Case: 3:15-cr-01298-AJB. https://extremism.gwu.edu/sites/extremism.gwu.edu/files/ Kodaimati\%20Criminal\%20Complaint.pdf, pp. 17-18

90. Ibid., p. 17.

91. Ibid., pp. 15-18

92. Heinke, Daniel, and Jan Raudzus. 2015. "German Foreign Fighters in Syria and Iraq.” CTC Sentinel 8 (1). https://ctc.usma.edu/posts/german-foreign-fighters-insyria-and-iraq.

93. Ibid.

94. "Criminal Complaint and Affidavit." USA v. Mohamad Saeed Kodaimati. pp. 16-18

95. Heinke and Raudzus, "German Foreign Fighters in Syria and Iraq."

96. A minor discrepancy in Kodaimati's account of this event is that the U.S. diplomatic facility in Ankara is an embassy, not a consulate. "Letter to Judge Battaglia." 2016. USA v. Mohamad Saeed Kodaimati, United States District Court for the Southern District of California. Case: 3:15-cr-01298-AJB.

97. "Criminal Complaint and Affidavit." USA v. Mohamad Saeed Kodaimati.p. 5

98. Ibid., pp. 5-6

99. Ibid., p. 10

100. Ibid., p. 10-11

101. Ibid., pp. 10-12

102. Ibid., p. 20

103. Ibid., pp. 21-22 
104. Ibid., p. 20

105. Ibid., p. 20

106. Ibid., pp. 20-22

107. "Letter to Judge Battaglia." USA v. Mohamad Saeed Kodaimati.

108. Ibid.

109. Ibid.

110. "Criminal Complaint and Affidavit." USA v. Mohamad Saeed Kodaimati, pp. 6-9

111. Ibid., pp. 6-9

112. Ibid., p. 9

113. Ibid., pp. 25-26

114. "San Diego Man Pleads Guilty, Admits Making False Statements in an International Terrorism Investigation." 2015. Press Release. FBI. October 29, 2015. https:// www.fbi.gov/contact-us/field-offices/sandiego/news/ press-releases/san-diego-man-pleads-guilty-admitsmaking-false-statements-in-an-international-terrorisminvestigation.

115. "San Diego Man Sentenced to 96 Months in Prison for Making False Statements in an International Terrorism Investigation.” 2016. DOJ Press Release. March 14, 2016. https://www.justice.gov/usao-sdca/pr/san-diego-mansentenced-96-months-prison-making-false-statementsinternational.

116. Krause, Kevin. 2017. "FBI Says Men from Plano Went to Fight with ISIS and Their Parents Lied about It." Dallas News. October 10, 2017. https://www.dallasnews.com/ news/crime/2017/10/10/fbi-says-young-men-plano-wentfight-isis-parents-lied

117. "Factual Basis.” 2017. USA v. Mohommad Hasnain Ali, United States District Court for the Eastern District of Texas. Case: 4:17-cr-00087-MAC-CAN. https://extremism.gwu.edu/ sites/extremism.gwu.edu/files/MAliFactualBasis.pdf, p. 1

118. Krause, "FBI Says Men from Plano Went to Fight with ISIS and Their Parents Lied about It."

119. Ibid.

120. Ibid.

121. Authors' interview with returned traveler, June 19, 2017.

122. Ibid.

123. Wood, Graeme. 2017. "The American Climbing the Ranks of ISIS.” The Atlantic, March 2017. https:// www.theatlantic.com/magazine/archive/2017/03/ the-american-leader-in-the-islamic-state/510872.

124. Ibid.

125. Ibid.

126. Ibid.

127. Ibid.
128. Ibid.

129. Ibid.

130. "Inside the Khilafa”. 2017. Al-Hayat Media Center, June 28.

131. "Factual Basis." USA v. Mohommad Hasnain Ali, pp. 1-2

132. Krause, "FBI Says Men from Plano Went to Fight with ISIS and Their Parents Lied about It.”

133. "Factual Basis." USA v. Mohommad Hasnain Ali, pp. 1-2

134. Ibid., p. 2

135. Ibid., pp. $2-3$

136. Krause, "FBI Says Men from Plano Went to Fight with ISIS and Their Parents Lied about It."

137. Ibid.

138. Williams, Michael J., John G. Horgan, and William P. Evans. 2016. "The Critical Role of Friends in Networks for Countering Violent Extremism: Toward a Theory of Vicarious Help-Seeking." Behavioral Sciences of Terrorism and Political Aggression 8 (1):45-65. https://doi.org/10.1080/ 19434472.2015.1101147.

139. Ibid.

140. Sageman, Marc. 2011. Leaderless Jihad: Terror Networks in the Twenty-First Century. University of Pennsylvania Press: Philadelphia, Pennsylvania.

141. Ibid.

142. "Criminal Complaint." 2015. USA v. Asher Abid Khan, United States District Court for the Southern District of Texas. Case: H15-712 M. https://extremism.gwu.edu/sites/ extremism.gwu.edu/files/Khan\%2C\%20A.\%20Criminal\%20 Complaint.pdf.

143. Ibid.

144. “Arraignment/Detention Hearing." 2015. USA v. Asher Abid Khan, United States District Court for the Southern District of Texas. Case: H15-712 M, p. 14

145. Ibid., pp. 15-16

146. Ibid., p. 16

147. Ibid., p. $16-18$

148. Ibid., p. 18

149. Ibid., p. 18

150. Goldman, Adam. 2015. “An American Family Saved Their Son from Joining the Islamic State. Now He Might Go to Prison.” Washington Post, September 6, 2015, sec. National Security. https://www.washingtonpost.com/world/ national-security/an-american-family-saved-their-sonfrom-joining-the-islamic-state-now-he-might-go-toprison/2015/09/06/2d3d0f48-44ef-11e5-8ab4c73967a143d3_story.html.

151. Ibid.

96 | THE GEORGE WASHINGTON UNIVERSITY PROGRAM ON EXTREMISM 
152. “Arraignment/Detention Hearing," USA v. Asher Abid Khan. p. 19

153. "Criminal Complaint," USA v. Asher Abid Khan. pp. 10-11

154. Ibid., p. 11

155. Ibid., p. 12

156. Ibid., pp. 12-13

157. Ibid., p. 13

158. Ibid., p. 13

159. Ibid., p. 13

160. Goldman, "An American Family Saved Their Son from Joining the Islamic State. Now He Might Go to Prison."

161. Ibid.

162. Ibid.

163. Ibid.

164. This document, alongside numerous other court filings, were sealed until October 2017. Despite no public announcement of the charges or the unsealing, Program on Extremism researchers uncovered the documents shortly thereafter. "Criminal Complaint." 2015. USA v. Brian Arthur Dempsey, Sr., United States District Court for the Eastern District of California. Case: 2:16-cr-00119-MCE. p. 2

165. Ibid., p. 2

166. Authors' interview with source with knowledge of the investigation, October 20, 2017.

167. Criminal Complaint," USA v. Brian Arthur Dempsey, Sr. pp. 2-4

168. Ibid., p. 3

169. Ibid., pp. 2-3

170. Ibid., pp. 2-3

171. Ibid., p. 3

172. Documents provided to the Program on Extremism by an Italian law enforcement source.

173. "Criminal Complaint," USA v. Brian Arthur Dempsey, Sr., pp. 3-4

174. Ibid., pp. 5-6

175. The complaint was kept under seal until 2015 , out of the fear that releasing it could affect the investigation into Person A, or that Dempsey would contact and coerce key government sources. Ibid., pp. 5-6.

176. "Petition to Unseal Indictment." 2017. USA v. Brian Arthur Dempsey, Sr., United States District Court for the Eastern District of California. Case: 2:16-cr-00119-MCE. pp. 1-2.

177. Authors' interview with source with knowledge of the investigation, October 20, 2017.

178. Ibid.
179. Berger, J.M. 2016. "Without Prejudice: What Sovereign Citizens Believe." Occasional Paper. Program on Extremism. https://extremism.gwu.edu/sites/extremism.gwu.edu/ files/downloads/JMB\%20Sovereign\%20Citizens.pdf.

180. Hallissy, Erin. 1995. "Lien and Mean / Intimidation of Government Officials with Pseudo-Legal Claims on Their Property and the Chilling Ambush of a County Recorder Herald an Ominous New Direction for the Anti-Tax Movement." SFGate. July 16, 1995. http://www.sfgate. com/crime/article/Lien-and-Mean-Intimidation-ofgovernment-3028395.php.

181. Ibid.

182. Ibid.

183. Ibid.

184. Ibid.

185. Ibid.

186. Sageman, Marc. 2004. Understanding Terror Networks. University of Pennsylvania Press: Philadelphia, PA.

187. Criminal Complaint." USA v. Mohamed Abdihamid Farah et. al, pp. 25-26

188. Ibid., p. 26

189. Authors' interview with senior U.S. law enforcement official involved in the investigation, November 2017.

190. Coolsaet, Rik. 2016. "Facing the Fourth Foreign Fighters Wave: What Drives Europeans to Syria, and to Islamic State? Insights from the Belgian Case." 81. Egmont Paper. Egmont Royal Institute for International Affairs. http:// www.egmontinstitute.be/content/uploads/2016/02/egmont. papers.81_online-versie.pdf?type=pdf. Holman, Timothy. 2016. "'Gonna Get Myself Connected': The Role of Facilitation in Foreign Fighter Mobilizations." Perspectives on Terrorism 10 (2). http://www.terrorismanalysts.com/pt/index.php/pot/ article/view/497; Marone, Francesco. 2017. "Ties That Bind: Dynamics of Group Radicalisation in Italy's Jihadists Headed for Syria and Iraq." The International Spectator 52 (3):48-63. https://doi.org/10.1080/03932729.2017.1322800.

\section{Category 3: Loners}

1. Quotations in this section are derived from the authors' interview with "Mo", May 9, 2017.

2. The trial occurred in the U.S. District Court for the Eastern District of Virginia in June of 2017.

3. Peters, Rudolph. 2008. "Dutch Islamist Extremism: Van Gogh's Murderer and His Ideas.” In Jihadi Terrorism and the Radicalisation Challenge in Europe, 115-27. Farnham, UK: Asghate.

4. Ibid.

5. Ingram, Haroro J. 2017. “Learning from ISIS’s Virtual Propaganda War for Western Muslims: A Comparison 
of Inspire and Dabiq." In Terrorists' Use of the Internet: Assessment and Response, edited by M. Conway, L. Jarvis, O. Lehane, Stuart Macdonald, and Lella Nouri. Amsterdam, the Netherlands: IOS Press.

6. Horgan, John. 2008. "From Profiles to Pathways and Roots to Routes: Perspectives from Psychology on Radicalization into Terrorism." The ANNALS of the American Academy of Political and Social Science 618 (1):80-94. https://doi. org/10.1177/0002716208317539; Wiktorowicz, Quintan. 2005. Radical Islam Rising: Muslim Extremism in the West. Oxford, UK: Rowman \& Littlefield.

7. For more on the enduring relevance of Anwar al-Awlaki's work, see Meleagrou-Hitchens, "As American as Apple Pie: How Anwar Al-Awlaki Became the Face of Western Jihad."; Shane, Scott. 2016. Objective Troy: A Terrorist, a President, and the Rise of the Drone. New York: Tim Duggan Books.

8. Dawson and Amarasingam. "Talking to Foreign Fighters: Insights into the Motivations for Hijrah to Syria and Iraq."

9. Ibid.

10. Ibid.

11. Winter, Charlie. 2015. “The Virtual 'Caliphate': Understanding Islamic State's Propaganda Strategy.” London, UK: Quilliam.

12. Bukay, David. 2006. "The Religious Foundations of Suicide Bombings." Middle East Quarterly 13 (4), September. http://www.meforum.org/1003/ the-religious-foundations-of-suicide-bombings.

13. Ibid.

14. Burke, Jason. 2014. "Indian Police Arrest Owner of proIslamic State Twitter Account.” The Guardian, December 13. http://www.theguardian.com/world/2014/dec/13/ india-isis-twitter-mehdi-masroor-biswas-shamiwitness.

15. Weaver, Mary Anne. 2015. “Her Majesty's Jihadists.” The New York Times, April 14. https://www.nytimes.com/ 2015/04/19/magazine/her-majestys-jihadists.html.

16. This description potentially matches Anatoli Zemlyanka (aka "Jihadi Tolik"), a Russian ex-Neo-Nazi from Siberia who converted to Islam and joined IS in Syria. He appeared in a 2015 beheading video. Sonne, Paul. 2015. "Russia Grapples With Its Own 'Jihadi John,' as Moscow Steps Up Role in Syria." Wall Street Journal, December 15. http://www.wsj. com/articles/russia-grapples-with-its-own-jihadi-johnas-moscow-steps-up-role-in-syria-1450175412.

17. Engel et. al., "The Americans: 15 Who Left the U.S. to Join ISIS."

18. Omar's real name and identity are unknown. It is unclear whether he was a member of the aforementioned cluster of IS recruits from the Minnesota Twin Cities.

19. Authors' interview with senior law enforcement official familiar with the investigation, May 2017.
20. "Government's Amended Trial Exhibit List, Exhibits 29A 29B." 2017. USA v. Mohamad Jamal Khweis, United States District Court for the Eastern District of Virginia. Case 1:16-cr-00143.

21. Ibid.

22. Kheel, Rebecca. 2016. "Report: American ISIS Fighter Captured.” TheHill. March 14, 2016. http://thehill.com/ policy/defense/272884-reports-american-isis-fightercaptured-while-defecting.

23. Zapotosky, Matt, and Rachel Weiner. 2016. "American ISIS Fighter Who 'found It Hard' Returns to Face Criminal Charges." Washington Post, June 9. https://www. washingtonpost.com/world/national-security/americanisis-fighter-who-found-it-hard-returns-to-face-criminalcharges/2016/06/08/b6990ea2-efa5-11e5-a61fe9c95c06edca_story.html.

24. Much of the subsequent analysis of this case is based on the authors' observations of Khweis court proceedings, in which details that are not found in the court documents were revealed by federal prosecutors.

25. Weiner, Rachel. 2017. "What life inside the Islamic State looks like for recruits." Washington Post, June 6. https://www.washingtonpost.com/local/public-safety/ islamic-state-recruit-testifies-i-just-wanted-to-see-theother-side/2017/06/06/54853ae6-47b1-11e7-98cdaf64b4fe2dfc_story.html.

26. "Trial Transcript." 2017. USA v. Mohamad Jamal Khweis, United States District Court for the Eastern District of Virginia. Case 1:16-cr-00143. p. 741

27. Ibid., p. 678

28. Ibid., p. 798

29. Ibid., p. 908

30. Ibid., p. 622

31. Ibid., p. 579

32. Ibid., p. 909

33. Ibid., pp. $752-754$

34. Ibid., p. 754.

35. The Google Mail account, mkhweis123, was created on December 12th. Ibid., p. 952

36. Ibid., p. 537

37. Ibid., p. 537

38. Ibid., p. 537

39. Ibid., p. 692

40. Ibid., pp. 1012-1013

41. Among the physical evidence recovered by the FBI from Khweis was three mobile phones (a Samsung Galaxy, iPhone, and a Blu phone) and two sim cards. The phones all 
had the cameras covered by tape, presumably a measure taken to prevent authorities from possibly accessing these and surveilling his activities. The activity on Khweis' phone that investigators were able to uncover helped them to both map out his route from Virginia to Syria and what his intentions were once arriving there. Among his location searches were a map of Gatwick Airport in London, along with maps of Istanbul and Gaziantep in Turkey. He used Google Maps to view the Gaziantep area and query which border crossings were controlled by IS. These searches matched to locations where Khweis' phone had connected to wireless routers, with investigators identifying connections at Gatwick Airport in the UK on the 17th of December 2015, in Istanbul on the 20th, in Gaziantep on the 24th, and the border town of Elbaily on the 23rd, 24th and 25th. He also made a number of revealing inquiries on Google, searching names such as "Al amriki", "Abu zak al Canada", "Al Canada", "Al Canada in Arabic", and "Al Kanadi." Other search terms included translations into Turkish of "how do I get to Gaziantep”, "can you take a bus", "can you take a train", "good morning" and "thank you." "Government's Amended Trial Exhibit List, Exhibits 4-26, 36-42, 57-71." USA v. Mohamad Jamal Khweis.

42. The Apple ID 001Freedom007, registered to Khweis, was used to create the account. Trial Transcript, USA v. Mohamad Jamal Khweis, p. 1024.

43. Ibid., p. 702

44. Virtual private networks, or VPNs, allow users of public internet networks to access private networks that otherwise might be geographically restricted. Tor is a downloadable browser which allows its users to browse the internet anonymously, masking their location and activity through relaying connections via several nodes, rather than making a single, traceable connection.

45. "Government's Amended Trial Exhibit List, Exhibits 64 and 67." USA v. Mohamad Jamal Khweis.

46. Ibid.

47. "Trial Transcript," USA v. Mohamad Jamal Khweis, pp. 703-704.

48. Ibid., p. 704

49. The account he contacted was @islamispeacexxx. Ibid., 975-981.

50. Ibid. p. 657

51. The National Investigation Agency of India, in a 2016 case, found that this account's owner was connected to the recruitment of an Indian national to join IS in Syria. "Charge Sheet." 2016. State (NIA) v/s Mohamed Naser and Others, Honourable Special Court, NIA Patiala House Courts, New Delhi, India. http://www.nia.gov.in/writereaddata/Portal/ CasesPdfDoc/CS_RC-14_2015_NIA_DLI-1.pdf.

52. Before his death in a coalition airstrike in September 2015, Parson was a member of "the Legion," a group of
English-speaking recruiters and attack planners who guided supporters in Anglophone countries to travel to join IS and commit attacks. He is connected to at least one attempted travel case in the U.S. Robles, Frances. 2017. "Trying to Stanch Trinidad's Flow of Young Recruits to ISIS.” The New York Times, February 21. https://www.nytimes. com/2017/02/21/world/americas/trying-to-stanchtrinidads-flow-of-young-recruits-to-isis.html.

53. "Trial Transcript," USA v. Mohamad Jamal Khweis, pp. 658-659

54. Ibid., p. 545

55. Ibid., pp. 990-999

56. Ibid., p. 990

57. Ibid., p. 997

58. Ibid., p. 992-994

59. Ibid., 999

60. Ibid., 1005-1007

61. Ibid., 1061-1062

62. Ibid., 1062

63. Callimachi, Rukmini. 2016. "How a Secretive Branch of ISIS Built a Global Network of Killers.” The New York Times, August 3. https://www.nytimes.com/2016/08/04/world/ middleeast/isis-german-recruit-interview.html.

64. Trial Transcript, USA v. Mohamad Jamal Khweis, pp. 1064-1065

65. Ibid, 734

66. Ibid., $736-738$

67. Ibid., 737

68. Ibid., 1090-1092

69. Ibid., 565-566

70. Ibid., 566-567

71. Ibid., 1028

72. Ibid., 891-897

73. Ibid., 897-898

74. Ibid., 903-905

75. “American Sentenced to 20 Years for Joining ISIS.” 2017. DOJ Press Release. October 27, 2017. https://www.justice. gov/opa/pr/american-sentenced-20-years-joining-isis.

76. Dalgaard-Nielsen, "Violent Radicalization in Europe: What We Know and What We Do Not Know."

77. Holman, “'Gonna Get Myself Connected': The Role of Facilitation in Foreign Fighter Mobilizations."

78. See, for instance, USA vs. Mohammed Hamza Khan; USA vs. Keonna Thomas; USA vs. Jaelyn Delshaun Young and Mohammad Oda Dakhlalla; USA vs. Haris Qamar; USA vs. Abdurasul 
Hasanovich Juraboev and Akhror Saidakhmetov, USA vs. Munir Abdulkader, etc.

79. Winter, “The Virtual Caliphate.”

\section{Returning American Travelers}

1. This report identifies 12 U.S. travelers by name. In 2015, former U.S. Director of National Intelligence James Clapper testified that as many as 40 Americans returned from fighting in jihadist groups in Syria. Reuters. 2015. "U.S. Spy Chief Says 40 Americans Who Went to Syria Have Returned," March 2, 2015. https://www.reuters.com/article/us-usasecurity-syria/u-s-spy-chief-says-40-americans-who-wentto-syria-have-returned-idUSKBNOLY2EB20150302.

2. Barrett, Richard. 2017. "Beyond the Caliphate: Foreign Fighters and the Threat of Returnees.” The Soufan Group. http://thesoufancenter.org/wp-content/uploads/2017/10/ Beyond-the-Caliphate-Foreign-Fighters-and-the-Threat-ofReturnees-TSC-Report-October-2017.pdf.

3. The 22 jihadist attacks in the U.S. from 2011 to 2017 are: 1. Car-ramming Attack on U.S. Marines, Seattle, WA, 7/12/2011; 2. Boston Marathon Bombing, Boston, MA, 4/15/2013; 3. Ali Muhammad Brown Murders, Seattle, WA and West Orange, NJ, 4/27/2017-6/25/2014; 4. ОкLAномA Vaughan Foods Beheading, Moore, OK, 9/24/2014; 5. Hatchet Attack on New York Police Officers, New York, NY, 10/23/2014; 6. John BAiley Clark JR. ShoOting, Morganton, NC 12/18/2014; 7. Curtis Culwell Center Muhammad Art Exhibit Shooting, Garland, TX, 5/3/2015; 8. Navy Reserve Shootings, Chattanooga, TN, 7/16/2015; 9. University of California, Merced (UCM) Stabbing, Merced, CA, 11/4/2015; 10. SAN BERnARDINO SHOOTING, San Bernardino, CA, 12/2/2015; 11. SHOoting OF Philadelphia Police Officer, Philadelphia, PA, 1/7/2016; 12. Restaurant Machete Attack, Columbus, OH, 2/11/2016; 13. Orlando Nightclub Shooting, Orlando, FL, 6/12/2016; 14. Roanoke Double Stabbing, Roanoke, VA, 8/20/2016; 15. Minnesota Mall Stabbing, St Cloud, MN, 9/17/2016; 16. Chelsea and Seaside Park Bombings, New York, NY and Seaside Park, NJ, 9/17-9/19/2016; 17. Ohio State University Campus Stabbing, Columbus, OH, 11/28/2016; 18. Ft. Lauderdale Airport Shooting, Ft. Lauderdale, FL, 1/6/2017; 19. Denver Transit OfFicer Shooting, Denver, CO, 1/31/2017; 20. Flint Airport StabBing, Flint MI, 6/22/2017; 21. Lower ManhatTan Truck-ramming AtTack, New York, NY, 10/31/2017; 22. Port Authority Bombing, New York, NY, 12/8/2017.

4. “TE-SAT 2013: EU Terrorism Situation and Trend Report." 2013. The Hague, Netherlands: Europol. https://www. europol.europa.eu/activities-services/main-reports/ eu-terrorism-situation-and-trend-report.

5. Hegghammer, “Should I Stay?” p. 12

6. Byman, Daniel, and Jeremy Shapiro. 2014. "Be Afraid, Be A Little Afraid: The Threat of Terrorism from Western
Foreign Fighters in Syria and Iraq.” Policy Paper 34. Brookings. https://www.brookings.edu/wp-content/ uploads/2016/06/Be-Afraid-web.pdf.

7. AFP. 2017. "Islamic State: What Happened to All the Foreign Fighters?” December 16. https://www.afp.com/en/news/23/ islamic-state-what-happened-all-foreign-fighters-doc-v76cq2.

8. Ibid.

9. Van Ginkel et. al., "The Foreign Fighters Phenomenon in the European Union”

10. Jenkins, "When Jihadis Come Marching Home"

11. Comey, James. 2014. "Worldwide Threats to the Homeland.” Statement by Director James B. Comey before the House Homeland Security Committee. Federal Bureau of Investigation. September 17. https://www.fbi.gov/news/ testimony/worldwide-threats-to-the-homeland.

12. Rasmussen, Nicholas. 2017. "Opening Remarks- CNAS Keynote Policy Address.” Center for a New American Security, May 3. https://www.dni.gov/files/NCTC/ documents/news_documents/CNASopeningremarks.pdf.

13. "New York Man Sentenced to 20 Years for Conspiring to Provide Material Support to ISIL in Connection With Planned New Year's Eve Attack.” 2017. Department of Justice Press Release. January 26. https://www.justice.gov/ opa/pr/new-york-man-sentenced-20-years-conspiringprovide-material-support-isil-connection-planned.

14. Ibid.

15. Ibid.

16. Nesser, Petter, Anne Stenersen, and Emilie Oftedal. 2016. "Jihadi Terrorism in Europe: The IS-Effect." Perspectives on Terrorism 10 (6). http://www.terrorismanalysts.com/pt/ index.php/pot/article/view/553.

17. “Terrorism in America after 9/11.” n.d. New America. Accessed November 18, 2017. https://www.newamerica. org/in-depth/terrorism-in-america/who-are-terrorists.

18. Hegghammer, Thomas, and Petter Nesser. 2015. "Assessing the Islamic State's Commitment to Attacking the West.” Perspectives on Terrorism 9 (4). http://www.terrorismanalysts.com/pt/ index.php/pot/article/view/440.

19. Ibid.

20. Ibid.

21. Ibid.

22. One notable exception is the July 14, 2016 truck-ramming attack in Nice, France, which killed 86 people. In this case, the attacker, Mohamed Lahouaiej-Bouhlel, was not known to have returned from Syria or Iraq. BBC News. 2016. "Attack in Nice: What We Know,” August 19, 2016, sec. Europe. http://www.bbc.com/news/world-europe-36801671.

23. Wright, Christopher J. 2016. "How Dangerous Are Domestic Terror Plotters with Foreign Fighter Experience? The Case of 
Homegrown Jihadis in the US." Perspectives on Terrorism 10 (1). http://www.terrorismanalysts.com/pt/index.php/pot/article/ view/487.

24. "Statement of Facts." 2015. USA v. Abdirahman Sheik Mohamud, United States District Court for the Southern District of Ohio 2:15-cr-00095-JLG-EPD. https://www. justice.gov/opa/press-release/file/977026/download.

25. Ibid.

26. Ibid.

27. Ibid.

28. Ibid.

29. Ibid.

30. Ibid.

31. Ibid.

32. Ibid.

33. "Aafia Siddiqui Sentenced in Manhattan Federal Court to 86 Years for Attempting to Murder U.S. Nationals in Afghanistan and Six Additional Crimes." 2010. FBI. September 23. https://www.fbi.gov/newyork/pressreleases/2010/nyfo092310.htm.

34. "Statement of Facts." USA v. Abdirahman Sheik Mohamud.

35. Ibid.

36. Ibid.

37. Ibid.

38. Ibid.

39. Ibid.

40. Ibid.

41. Gray, Kathy Lynn. 2015. "Columbus Man Indicted on Terrorism Charges by Federal Grand Jury." The Columbus Dispatch. April 16. http://www.dispatch.com/ article/20150416/NEWS/304169763.

42. Ibid.

43. Ibid.

44. "Columbus Man Sentenced for Providing Material Support to Terrorists, Making False Statements to Authorities.” 2018. DOJ Press Release. January 22, 2018. https://www.justice.gov/usao-sdoh/pr/columbus-mansentenced-providing-material-support-terrorists-makingfalse-statements.

45. Wood, "The American Climbing the Ranks of ISIS."

46. Hughes and Clifford, "First He Became an American-Then He Joined ISIS.”

47. Schmidt, Michael S., and Mark Mazzetti. 2014. "Suicide Bomber From U.S. Came Home Before Attack." The New York Times, July 30. https://www.nytimes.com/2014/07/31/ us/suicide-bomber-from-us-came-home-before-attack.html.
48. Ibid.

49. Ibid.

50. Christian Science Monitor. 2014. "Sinh Vinh Ngo Nguyen Sentenced to 13 Years for Trying to Aid Al Qaeda," June 30. https://www.csmonitor.com/USA/Latest-NewsWires/2014/0630/Sinh-Vinh-Ngo-Nguyen-sentenced-to13-years-for-trying-to-aid-al-Qaeda.

51. Ibid.

52. Ibid.

53. Mendick, Robert, and Robert Verkaik. 2016. "Only One in Eight Jihadists Returning to UK Is Caught and Convicted.” The Telegraph, May 21, 2016. http://www.telegraph.co.uk/ news/2016/05/21/only-one-in-eight-jihadists-returning-touk-is-caught-and-convic.

54. Ibid.

55. Ibid.

56. "GW Extremism Tracker," Program on Extremism.

57. "18 U.S. Code $§ 1001$ - Statements or Entries Generally." n.d. LII / Legal Information Institute. Accessed November 18, 2017. https://www.law.cornell.edu/uscode/text/18/1001.

58. Doyle, "Terrorist Material Support: An Overview of 18 U.S.C. \$2339A and §2339B.”

59. Bjelopera, Jerome. 2015. "Terror Inmates: Countering Violent Extremism in Prison and Beyond." Statement before the Committee on Homeland Security, Subcommittee on Counterterrorism and Intelligence, U.S. House of Representatives. http://docs.house.gov/meetings/HM/ HM05/20151028/104102/HHRG-114-HM05-WstateBjeloperaJ-20151028.pdf.

60. Ibid.

61. Brandon, James. 2009. "The Danger of Prison Radicalization in the West." CTC Sentinel 2 (12). https://ctc.usma.edu/ posts/the-danger-of-prison-radicalization-in-the-west; Basra, Rajan, Peter Neumann, and Claudia Brunner. 2016. "Criminal Pasts, Terrorist Futures: European Jihadists and the New Crime-Terror Nexus." London, UK: International Centre for the Study of Radicalisation. http://icsr.info/ wp-content/uploads/2016/10/Criminal-Pasts-TerroristFutures.pdf.

62. van Ginkel, Bibi. 2016. "Prosecuting Foreign Terrorist Fighters: What Role for the Military?” International Centre for Counter-terrorism- The Hague. https://www. icct.nl/wp-content/uploads/2016/05/ICCT-VanGinkelProsecuting-Foreign-Terrorist-Fighters-May2016-2.pdf.

\section{Addressing the Threat of American Jihadist Travelers}

1. Jenkins, "When Jihadis Come Marching Home”; Byman and Shapiro, "Be Afraid, Be A Little Afraid: The Threat 
of Terrorism from Western Foreign Fighters in Syria and Iraq."; Levitt, Matt. 2017. "America's Radicalization Problem: It's Local.” The Washington Institute. November 1. http://www.washingtoninstitute.org/policy-analysis/ view/americas-radicalization-problem-its-local.

2. While the sample is limited, women returning travelers have received lighter sentences than men. One women returnee was sentenced to two years in prison, and one was never charged, making the average sentence one year in prison. For the six male returnees that have received sentences, the average sentence is 9.2 years.

3. Kitfield, James. 2017. "Taking on 'Foreign Fighters': How the West Tracks-and Targets-Jihadis Fleeing the Collapse of ISIS.” Yahoo News, December 1. https://www.yahoo.com/ news/taking-foreign-fighters-west-tracks-targets-jihadisfleeing-collapse-isis-100045440.html.

4. "Prison Radicalization: The Environment, the Threat, and the Response." 2006. FBI. https://www.fbi.gov/news/ testimony/prison-radicalization-the-environment-thethreat-and-the-response.

5. Buchanan, Larry. 2016. "Uncovering the Links Between the Brussels and Paris Attackers." The New York Times, March 23. https://www.nytimes.com/interactive/2016/03/23/ world/europe/how-the-brussels-and-paris-attackerscould-be-connected.html.

6. "Responses to Returnees: Foreign Terrorist Fighters and Their Families." 2017. Radicalization Awareness Network. https://ec.europa.eu/home-affairs/sites/homeaffairs/files/ $\underline{\text { ran_br_a4_m10_en.pdf. }}$

7. Ibid.

8. Horgan, John, and Kurt Braddock. 2010. "Rehabilitating the Terrorists? Challenges in Assessing the Effectiveness of De-Radicalization Programs." Terrorism and Political Violence 22 (2):267-91. https://doi.org/10.1080/ 09546551003594748 .

9. Authors' interview with senior law enforcement official involved in this program, November 2017.

10. Alkhouri, Laith, and Alex Kassirer. 2016. "Tech for Jihad: Dissecting Jihadists Digital Toolbox." Flashpoint. https://www.flashpoint-intel.com/wp-content/uploads/ 2016/08/TechForJihad.pdf.

11. Rosenstein, Rod. 2017. “Deputy Attorney General Rod J. Rosenstein Delivers Remarks at the Global Cyber Security Summit." presented at the Global Cyber Security Summit, London, UK, October 13. https://www.justice.gov/opa/ speech/deputy-attorney-general-rod-j-rosenstein-deliversremarks-global-cyber-security-summit.
12. Travis, Alan. 2017. "Amber Rudd: Viewers of Online Terrorist Material Face 15 Years in Jail." The Guardian, October 2. http://www.theguardian.com/uk-news/2017/ oct/03/amber-rudd-viewers-of-online-terrorist-materialface-15-years-in-jail.

13. Elgot, Jessica. 2017. "May and Macron Plan Joint Crackdown on Online Terror." The Guardian, June 12. http://www.theguardian.com/politics/2017/jun/12/may$\underline{\text { macron-online-terror-radicalisation. }}$

14. "Government's Amended Trial Exhibit List, Exhibits 64 and 67." USA v. Mohamad Jamal Khweis.

15. Eng, James. 2015. "FBI Director: Encrypted Messages Stymied Probe of 'Draw Muhammad' Shooting." NBC News. December 9, 2015. https://www.nbcnews.com/tech/ security/fbi-director-encrypted-messages-stymiedprobe-garland-shooting-n 477111.

16. Reuters. 2016. "France Says Fight against Messaging Encryption Needs Worldwide Initiative," August 11, 2016. https://www.reuters.com/article/us-france-internetencryption/france-says-fight-against-messagingencryption-needs-worldwide-initiative-idUSKCN10M1KB.

17. For instance, Ackerman, Spencer. 2015. "FBI Chief Wants 'Backdoor Access' to Encrypted Communications to Fight Isis." The Guardian, July 8. http://www.theguardian. com/technology/2015/jul/08/fbi-chief-backdoor-accessencryption-isis; Haynes, Jonathan. 2017. "Backdoor Access to WhatsApp? Rudd's Call Suggests a Hazy Grasp of Encryption." The Guardian, March 27. http://www. theguardian.com/technology/2017/mar/27/amber-ruddcall-backdoor-access-hazy-grasp-encryption.

18. Brantly, Aaron. 2017. "Banning Encryption to Stop Terrorists: A Worse than Futile Exercise." CTC Sentinel 10 (7). https://ctc.usma.edu/posts/banning-encryption-to-stopterrorists-a-worse-than-futile-exercise.

19. Ra, Markus. 2017. "Don't Shoot the Messenger." Telegraph. March 27, 2017. http://telegra.ph/Dont-Shoot-the-Messenger.

\section{Conclusion}

1. Basra et. al., "Criminal Pasts, Terrorist Futures: European Jihadists and the New Crime-Terror Nexus."

2. The figure in our sample stands at 28 , but this is unlikely to be the full number as it only reflects the cases about which there are enough details to determine the identity of the traveler. 



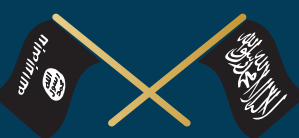

Hundreds of Americans have been drawn to jihadist organizations fighting in Syria and Iraq. Many were arrested while attempting to make the journey. The 64 individuals identified in this study all reached their destinations.

This study sheds light on the motivations, methods, and threat posed by these travelers.

\section{Program on Extremism}

THE GEORGE WASHINGTON UNIVERSITY

EXTREMISM.GWU.EDU |@GWUPOE 